\title{
Synthetic simplification of carolacton enables chemical genetic studies in Streptococcus mutans
}

Amy E. Solinski, ${ }^{[a]}$ Amber M. Scharnow, ${ }^{[a]}$ Americo J. Fraboni, ${ }^{[a]}$ and William M. Wuest*[a,b]

aDepartment of Chemistry, Emory University, 1515 Dickey Drive, Atlanta GA 30322

${ }^{\mathrm{b}}$ Antibiotic Resistance Center, Emory University School of Medicine, 201 Dowman Drive, Atlanta GA 30322

Table of Contents:

I. Supplementary Figures

- Figure S1. Hydrogenation Conditions ............................... 2

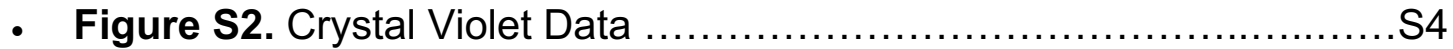

- Figure S3. Mutant Screen Results ............................... 7

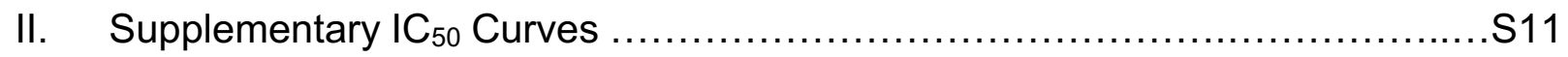

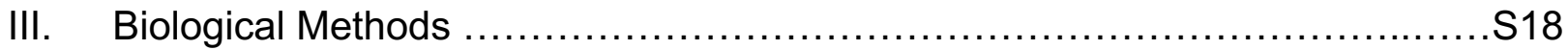

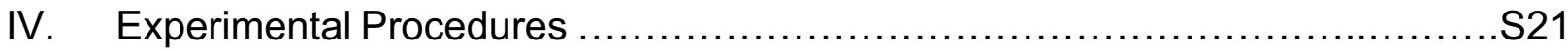

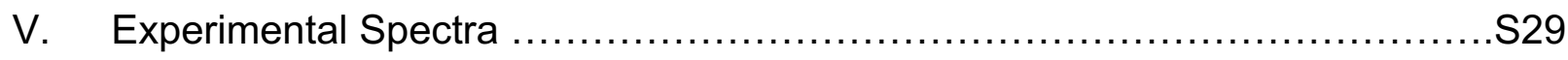

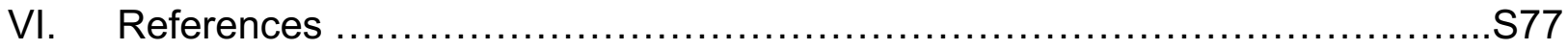




\section{Supplemental Figures}

Figure S1: Table of hydrogenation conditions used in optimization. Data shown is not comprehensive but demonstrates the scope of reaction conditions that were attempted.

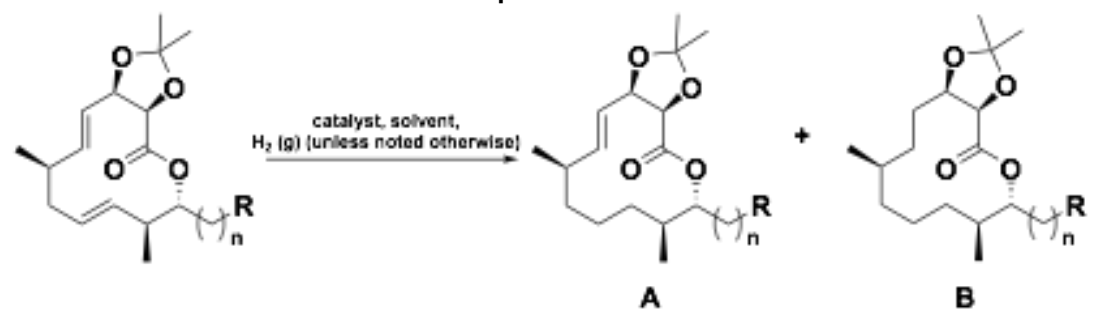

\begin{tabular}{|c|c|c|c|c|c|}
\hline $\mathbf{R}$ & Catalyst & $\begin{array}{l}\text { Catalyst } \\
\text { Load }\end{array}$ & Solvent & $\begin{array}{l}\text { Reaction } \\
\text { Time }\end{array}$ & $\begin{array}{c}\text { Conversion } \\
\text { (SM:A:B) }\end{array}$ \\
\hline \multirow{8}{*}{$-\mathrm{CO}_{2} \mathrm{Bn}$} & $\mathrm{Pd} / \mathrm{C}(10 \%)$ & $7 \mathrm{~mol} \%$ & EtOAc & $20 \mathrm{hrs}$ & NR \\
\hline & $\mathrm{Pd} / \mathrm{C}(10 \%)$ & $20 \mathrm{~mol} \%$ & EtOH & $45 \mathrm{~min}$ & $0: 54: 46$ \\
\hline & $\mathrm{Pd} / \mathrm{C}(10 \%)$ & $7 \mathrm{~mol} \%$ & EtOH & $10 \mathrm{~min}$ & NR \\
\hline & $\mathrm{Pd} / \mathrm{C}(10 \%)$ & $10 \mathrm{~mol} \%$ & $\begin{array}{c}\text { EtOAc:MeOH } \\
(1: 1)\end{array}$ & $45 \mathrm{~min}$ & $0: 67: 33$ \\
\hline & $\mathrm{Pd} / \mathrm{C}(10 \%)$ & $26 \mathrm{~mol} \%$ & $\begin{array}{c}\text { EtOAc:MeOH } \\
(1: 1)\end{array}$ & $30 \mathrm{~min}$ & $0: 75: 25$ \\
\hline & $\mathrm{Pd} / \mathrm{C}(10 \%)$ & $20 \mathrm{~mol} \%$ & $\begin{array}{c}\mathrm{MeOH}: \mathrm{EtOH} \\
(1: 1)\end{array}$ & $60 \mathrm{~min}$ & NR \\
\hline & $\mathrm{Pd} / \mathrm{C}(10 \%)$ & $10 \mathrm{~mol} \%$ & $\begin{array}{c}\text { EtOAc:EtOH } \\
(1: 1)\end{array}$ & $10 \mathrm{~min}$ & 0:90:10 \\
\hline & $\mathrm{Pd} / \mathrm{C}(10 \%)$ & $20 \mathrm{~mol} \%$ & $\begin{array}{c}\text { EtOAc:EtOH } \\
(3: 1)\end{array}$ & $30 \mathrm{~min}$ & 0:90:10 \\
\hline$-\mathrm{CO}_{2} \mathrm{H}$ & $\mathrm{Pd} / \mathrm{C}(10 \%)$ & $10 \mathrm{~mol} \%$ & $\begin{array}{c}\text { EtOAc:EtOH } \\
(1: 1)\end{array}$ & $20 \mathrm{~min}$ & $90: 2.5: 2.5$ \\
\hline \multirow{5}{*}{$-\mathrm{CH}_{2} \mathrm{OTBS}$} & $\mathrm{Pd} / \mathrm{C}(10 \%)$ & $7 \mathrm{~mol} \%$ & EtOAc & $60 \mathrm{~min}$ & NR \\
\hline & $\mathrm{Pd} / \mathrm{C}(10 \%)$ & $7 \mathrm{~mol} \%$ & EtOH & $90 \mathrm{~min}$ & $0: 0: 100$ \\
\hline & $\mathrm{Pd} / \mathrm{C}(10 \%)$ & $7 \mathrm{~mol} \%$ & EtOH & $90 \mathrm{~min}$ & NR \\
\hline & $\mathrm{Pd} / \mathrm{C}(10 \%)$ & $7 \mathrm{~mol} \%$ & $\begin{array}{c}\text { EtOAc:EtOH } \\
(1: 1)\end{array}$ & $60 \mathrm{~min}$ & $0: 70: 30$ \\
\hline & $\mathrm{Pd} / \mathrm{C}(10 \%)$ & $13 \mathrm{~mol} \%$ & $\begin{array}{c}\text { EtOAc:EtOH } \\
(1: 1)\end{array}$ & $60 \mathrm{~min}$ & $0: 84: 16$ \\
\hline$-\mathrm{CH}_{2} \mathrm{OH}$ & $\mathrm{Pd} / \mathrm{C}(10 \%)$ & $13 \mathrm{~mol} \%$ & $\begin{array}{c}\text { EtOAc:EtOH } \\
(1: 1)\end{array}$ & $30 \mathrm{~min}$ & 0:0:100 \\
\hline
\end{tabular}




\begin{tabular}{|c|c|c|c|c|c|}
\hline & $\mathrm{Pd} / \mathrm{C}(10 \%)$ & $13 \mathrm{~mol} \%$ & $\begin{array}{c}\text { EtOAc:EtOH } \\
(1: 1)\end{array}$ & $20 \mathrm{~min}$ & $0: 77: 33$ \\
\hline & $\begin{array}{c}\mathrm{Pd} / \mathrm{C}(10 \%) \mathrm{wl} \\
\mathrm{HCO}_{2} \mathrm{NH}_{4}\end{array}$ & $8 \mathrm{~mol} \%$ & $\begin{array}{c}\text { EtOAc:MeOH } \\
(1: 1)\end{array}$ & $48 \mathrm{hrs}$ & 91:9:0 \\
\hline & Wilkinson Cat. & $10 \mathrm{~mol} \%$ & EtOAc & $10 \mathrm{~min}$ & NR \\
\hline & Wilkinson Cat. & $10 \mathrm{~mol} \mathrm{\%}$ & EtOAc & 24 hrs & NR \\
\hline & Wilkinson Cat. & $20 \mathrm{~mol} \%$ & EtOH:THF (2:1) & $24 \mathrm{hrs}$ & $84: 16: 0$ \\
\hline & Wilkinson Cat. & $20 \mathrm{~mol} \%$ & EtOH:THF (2:1) & $48 \mathrm{hrs}$ & $43: 25: 7$ \\
\hline & Wilkinson Cat. & $20 \mathrm{~mol} \%$ & PhH & $24 \mathrm{hrs}$ & $67: 21: 12$ \\
\hline & $\mathrm{Pt} / \mathrm{C}(10 \%)$ & $10 \mathrm{~mol} \%$ & $\mathrm{MeOH}$ & $30 \mathrm{~min}$ & NR \\
\hline & $\mathrm{Pt} / \mathrm{C}(10 \%)$ & $10 \mathrm{~mol} \%$ & $\begin{array}{c}\text { MeOH:EtOAc } \\
(1: 1)\end{array}$ & $30 \mathrm{~min}$ & $81: 14: 5$ \\
\hline$-\mathrm{CH}_{2} \mathrm{OPMB}$ & $\mathrm{Pd} / \mathrm{C}(10 \%)$ & $7 \mathrm{~mol} \%$ & EtOH & $1.5 \mathrm{hrs}$ & $0: 71: 29$ \\
\hline
\end{tabular}


Figure S2. Table of crystal violet biofilm mass data (top). Values shown are the result of (CV OD $595 /$ growth $\mathrm{O}_{\mathrm{D} 600}$ ) to demonstrate biofilm formation relative to bacterial growth. Graphical representation of (CV OD $595 /$ growth $\left.\mathrm{O}_{\mathrm{D} 600}\right)$ (middle). Relative biofilm mass compared to DMSO control (bottom).

\begin{tabular}{|c|c|c|c|c|c|c|c|c|c|c|c|c|}
\hline Trial 1 & 500.00 & 250.00 & 125.00 & 63.00 & 32.00 & 16.00 & 8.00 & 4.00 & 2.00 & 1.00 & 0.50 & 0.25 \\
\hline 9 & 11.21 & 11.25 & 10.63 & 8.80 & 7.11 & 6.12 & 5.76 & 5.75 & 6.11 & 5.91 & 5.76 & 5.80 \\
\hline 10 & 11.61 & 9.87 & 9.90 & 9.19 & 6.83 & 6.33 & 5.91 & 5.71 & 5.64 & 6.73 & 7.26 & 6.36 \\
\hline 2 & 1.03 & 1.77 & 11.96 & 12.07 & 10.56 & 7.43 & 6.29 & 5.99 & 6.52 & 6.43 & 6.12 & 5.79 \\
\hline carolacton & 11.05 & 12.25 & 7.67 & 7.57 & 7.54 & 6.73 & 6.58 & 6.83 & 6.61 & 6.87 & 6.96 & 7.90 \\
\hline DMSO & 7.63 & 7.13 & 6.91 & 7.04 & 7.16 & 7.39 & 6.94 & 7.45 & 7.04 & 7.28 & 6.89 & 6.70 \\
\hline Trial 2 & 500.00 & 250.00 & 125.00 & 63.00 & 32.00 & 16.00 & 8.00 & 4.00 & 2.00 & 1.00 & 0.50 & 0.25 \\
\hline 9 & 3.90 & 8.55 & 7.55 & 5.84 & 5.84 & 4.69 & 4.65 & 6.08 & 4.31 & 4.90 & 5.33 & 3.51 \\
\hline 10 & 11.19 & 7.49 & 5.93 & 6.81 & 5.53 & 4.76 & 5.23 & 4.67 & 5.03 & 4.75 & 4.56 & 5.42 \\
\hline 2 & 2.94 & 2.32 & 10.45 & 8.79 & 6.35 & 7.26 & 6.11 & 4.66 & 5.41 & 6.49 & 4.66 & 5.05 \\
\hline carolacton & 10.00 & 7.37 & 8.28 & 6.27 & 6.40 & 5.65 & 5.89 & 6.09 & 6.45 & 5.63 & 5.48 & 5.68 \\
\hline DMSO & 7.25 & 5.64 & 7.28 & 5.92 & 6.72 & 6.75 & 8.14 & 6.53 & 6.26 & 6.14 & 5.76 & 5.18 \\
\hline Trial 3 & 500.00 & 250.00 & 125.00 & 63.00 & 32.00 & 16.00 & 8.00 & 4.00 & 2.00 & 1.00 & 0.50 & 0.25 \\
\hline 9 & 4.63 & 7.02 & 7.50 & 7.44 & 6.98 & 5.00 & 4.97 & 5.52 & 4.82 & 6.86 & 6.17 & 6.70 \\
\hline 10 & 10.42 & 12.18 & 7.39 & 5.94 & 6.30 & 5.38 & 5.23 & 5.27 & 5.32 & 5.41 & 6.84 & 5.14 \\
\hline 2 & 1.78 & 1.16 & 7.89 & 8.74 & 6.54 & 5.98 & 6.75 & 5.46 & 5.58 & 5.77 & 5.04 & 5.70 \\
\hline carolacton & 10.35 & 8.35 & 6.29 & 5.12 & 6.31 & 6.64 & 6.99 & 6.53 & 6.28 & 6.55 & 5.33 & 5.64 \\
\hline DMSO & 6.96 & 4.99 & 5.20 & 6.32 & 8.24 & 7.39 & 7.68 & 6.96 & 6.65 & 6.82 & 6.78 & 5.91 \\
\hline
\end{tabular}

\begin{tabular}{|c|c|c|c|c|c|c|c|c|c|c|c|c|}
\hline Trial $\mathbf{4}$ & $\mathbf{5 0 0 . 0 0}$ & $\mathbf{2 5 0 . 0 0}$ & $\mathbf{1 2 5 . 0 0}$ & $\mathbf{6 3 . 0 0}$ & $\mathbf{3 2 . 0 0}$ & $\mathbf{1 6 . 0 0}$ & $\mathbf{8 . 0 0}$ & $\mathbf{4 . 0 0}$ & $\mathbf{2 . 0 0}$ & $\mathbf{1 . 0 0}$ & $\mathbf{0 . 5 0}$ & $\mathbf{0 . 2 5}$ \\
\hline $\mathbf{9}$ & 4.39 & 6.33 & 4.39 & 4.08 & 4.06 & 3.34 & 3.65 & 2.08 & 2.02 & 2.32 & 2.16 & 1.53 \\
\hline $\mathbf{1 0}$ & 6.10 & 5.26 & 6.05 & 4.60 & 4.12 & 3.40 & 3.44 & 2.39 & 2.36 & 2.65 & 2.14 & 1.87 \\
\hline $\mathbf{2}$ & 1.12 & 1.57 & 6.81 & 4.51 & 3.64 & 2.35 & 2.06 & 1.79 & 2.07 & 2.45 & 2.21 & 2.08 \\
\hline carolacton & ---- & ---- & ---- & ---- & ---- & --- & --- & --- & --- & --- & --- & --- \\
\hline DMSO & 2.65 & 2.68 & 2.67 & 2.66 & 1.91 & 2.40 & 1.85 & 1.94 & 2.27 & 2.42 & 1.81 & 1.79 \\
\hline
\end{tabular}

\begin{tabular}{|c|c|c|c|c|c|c|c|c|c|c|c|c|}
\hline Trial 5 & 500.00 & 250.00 & 125.00 & 63.00 & 32.00 & 16.00 & 8.00 & 4.00 & 2.00 & 1.00 & 0.50 & 0.25 \\
\hline 9 & 5.70 & 7.83 & 8.95 & 8.76 & 5.54 & 5.27 & 4.89 & 3.33 & 3.73 & 3.78 & 2.87 & 2.96 \\
\hline 10 & 5.81 & 11.83 & 10.26 & 8.13 & 6.93 & 6.25 & 4.03 & 2.91 & 4.27 & 3.92 & 3.24 & 1.83 \\
\hline 2 & 1.17 & 1.93 & 10.88 & 6.70 & 5.01 & 5.22 & 4.30 & 2.80 & 3.35 & 3.64 & 2.53 & 2.24 \\
\hline carolacton & ----- & ----- & ----- & ----- & ----- & ----- & ----- & ----- & ----- & ----- & ----- & ----- \\
\hline DMSO & 2.79 & 3.26 & 3.50 & 2.82 & 2.89 & 3.86 & 3.42 & 3.30 & 2.73 & 3.20 & 2.68 & 2.43 \\
\hline
\end{tabular}




\begin{tabular}{|c|c|c|c|c|c|c|c|c|c|c|c|c|}
\hline Trial 6 & 500.00 & 250.00 & 125.00 & 63.00 & 32.00 & 16.00 & 8.00 & 4.00 & 2.00 & 1.00 & 0.50 & 0.25 \\
\hline 9 & 7.05 & 10.23 & 6.01 & 5.83 & 3.79 & 2.57 & 3.32 & 2.97 & 2.30 & 2.58 & 1.94 & 1.92 \\
\hline 10 & 5.12 & 6.06 & 5.14 & 5.17 & 2.89 & 4.55 & 3.36 & 2.49 & 2.53 & 2.12 & 2.24 & 2.16 \\
\hline 2 & 2.98 & 1.58 & 19.35 & 5.11 & 3.79 & 3.64 & 3.39 & 2.73 & 2.20 & 3.30 & 2.29 & 1.79 \\
\hline carolacton & ----- & ---- & ----- & ----- & ----- & ----- & ----- & ----- & ----- & ----- & ---- & ---- \\
\hline DMSO & 2.87 & 2.60 & 2.50 & 2.44 & 2.39 & 2.94 & 3.59 & 2.51 & 2.28 & 2.68 & 2.03 & 2.01 \\
\hline
\end{tabular}

\begin{tabular}{|c|c|c|c|c|c|c|c|c|c|c|c|c|}
\hline Trial 7 & 500.00 & 250.00 & 125.00 & 63.00 & 32.00 & 16.00 & 8.00 & 4.00 & 2.00 & 1.00 & 0.50 & 0.25 \\
\hline 9 & 4.35 & 6.30 & 6.94 & 5.69 & 4.98 & 4.02 & 3.19 & 2.68 & 2.62 & 2.70 & 3.04 & 2.52 \\
\hline 10 & 4.31 & 5.28 & 6.66 & 5.16 & 4.46 & 3.78 & 3.47 & 2.83 & 2.85 & 2.65 & 2.95 & 2.46 \\
\hline 2 & 1.13 & 1.18 & 8.66 & 5.83 & 4.45 & 3.46 & 3.22 & 3.16 & 2.58 & 2.47 & 2.90 & 2.48 \\
\hline carolacton & ----- & ----- & ----- & ----- & ----- & ----- & ----- & ----- & ----- & ----- & ----- & ----- \\
\hline DMSO & 4.04 & 3.60 & 3.62 & 3.33 & 3.49 & 3.51 & 3.03 & 2.88 & 2.78 & 2.53 & 2.89 & 2.72 \\
\hline
\end{tabular}

\begin{tabular}{|c|c|c|c|c|c|c|c|c|c|c|c|c|}
\hline Trial 8 & 500.00 & 250.00 & 125.00 & 63.00 & 32.00 & 16.00 & 8.00 & 4.00 & 2.00 & 1.00 & 0.50 & 0.25 \\
\hline 9 & 3.97 & 5.81 & 6.41 & 11.51 & 5.86 & 5.15 & 5.18 & 4.93 & 4.44 & 3.91 & 4.48 & 3.80 \\
\hline 10 & 4.95 & 5.43 & 8.13 & 7.27 & 6.07 & 4.88 & 4.82 & 4.18 & 4.20 & 3.82 & 4.99 & 2.98 \\
\hline 2 & 1.95 & 1.09 & 6.51 & 5.80 & 4.56 & 4.39 & 4.10 & 3.98 & 3.65 & 4.52 & 3.97 & 3.72 \\
\hline carolacton & ---- & ---- & ---- & ----- & ----- & ----- & ----- & ---- & ----- & ----- & ----- & ----- \\
\hline DMSO & 3.74 & 3.18 & 3.16 & 2.63 & 3.21 & 2.72 & 3.29 & 2.55 & 5.24 & 2.70 & 2.86 & 2.53 \\
\hline
\end{tabular}

\begin{tabular}{|c|c|c|c|c|c|c|c|c|c|c|c|c|}
\hline Trial 9 & 500.00 & 250.00 & 125.00 & 63.00 & 32.00 & 16.00 & 8.00 & 4.00 & 2.00 & 1.00 & 0.50 & 0.25 \\
\hline 9 & 3.40 & 6.01 & 6.73 & 5.22 & 3.05 & 2.78 & 2.38 & 2.44 & 2.12 & 2.24 & 2.04 & 1.69 \\
\hline 10 & 4.72 & 5.35 & 5.46 & 5.38 & 2.99 & 3.30 & 2.88 & 2.70 & 2.42 & 2.27 & 2.04 & 1.76 \\
\hline 2 & 1.19 & 1.33 & 4.68 & 5.77 & 3.63 & 2.75 & 3.00 & 2.22 & 2.25 & 2.07 & 1.91 & 2.42 \\
\hline carolacton & ----- & ----- & ----- & ----- & ----- & ----- & ----- & ----- & ----- & ----- & ---- & ----- \\
\hline DMSO & 4.27 & 2.83 & 2.71 & 2.47 & 2.22 & 2.45 & 2.28 & 2.80 & 2.33 & 1.99 & 2.54 & 2.22 \\
\hline
\end{tabular}

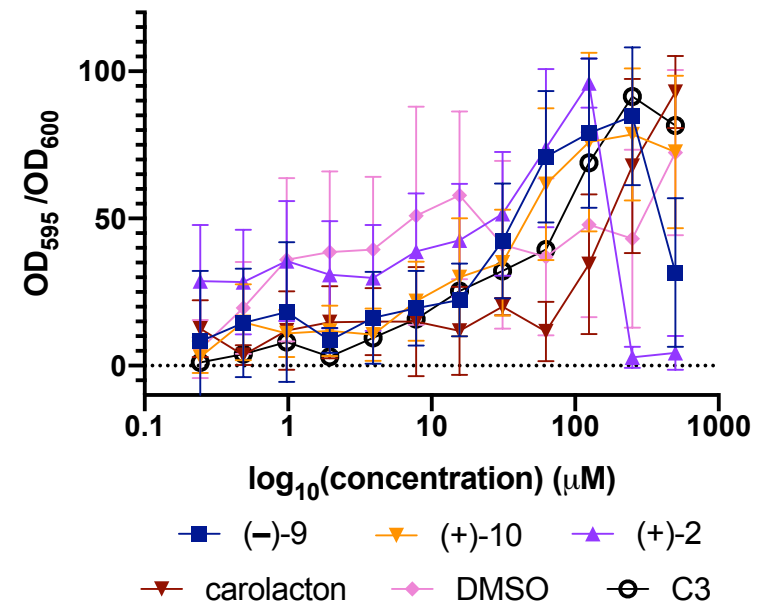




\begin{tabular}{|c|c|c|c|c|c|c|c|c|c|c|c|c|}
\hline & \multicolumn{10}{|c|}{ Relative Biomass Compared to DMSO control } \\
\hline conc $(\mu \mathrm{L})$ & $\mathbf{5 0 0 . 0 0}$ & $\mathbf{2 5 0 . 0 0}$ & $\mathbf{1 2 5 . 0 0}$ & $\mathbf{6 3 . 0 0}$ & $\mathbf{3 2 . 0 0}$ & $\mathbf{1 6 . 0 0}$ & $\mathbf{8 . 0 0}$ & $\mathbf{4 . 0 0}$ & $\mathbf{2 . 0 0}$ & $\mathbf{1 . 0 0}$ & $\mathbf{0 . 5 0}$ & $\mathbf{0 . 2 5}$ \\
\hline $\mathbf{9}$ & 1.00 & 1.82 & 1.63 & 1.72 & 1.18 & 0.94 & 0.90 & 0.92 & 0.79 & 0.92 & 0.92 & 0.88 \\
\hline $\mathbf{1 0}$ & 1.40 & 1.85 & 1.65 & 1.53 & 1.16 & 1.04 & 0.91 & 0.84 & 0.87 & 0.87 & 0.95 & 0.84 \\
\hline $\mathbf{2}$ & 0.36 & 0.39 & 2.32 & 1.78 & 1.27 & 1.08 & 0.97 & 0.89 & 0.89 & 1.04 & 0.92 & 0.99 \\
\hline carolacton & 1.44 & 1.58 & 1.15 & 0.98 & 0.91 & 0.88 & 0.86 & 0.93 & 0.97 & 0.94 & 0.91 & 1.08 \\
\hline
\end{tabular}

\begin{tabular}{|c|c|c|c|c|c|c|c|c|c|c|c|c|}
\hline & \multicolumn{10}{|c|}{ Average Biomass Trials 1-9 } \\
\hline DMSO & 4.69 & 3.99 & 4.17 & 3.96 & 4.25 & 4.38 & 4.47 & 4.10 & 4.18 & 3.97 & 3.80 & 3.50 \\
\hline $\mathbf{9}$ & 4.67 & 7.26 & 6.81 & 6.79 & 5.01 & 4.10 & 4.03 & 3.75 & 3.29 & 3.66 & 3.50 & 3.08 \\
\hline $\mathbf{1 0}$ & 6.58 & 7.36 & 6.88 & 6.06 & 4.91 & 4.54 & 4.06 & 3.43 & 3.62 & 3.45 & 3.62 & 2.95 \\
\hline $\mathbf{2}$ & 1.70 & 1.55 & 9.69 & 7.04 & 5.39 & 4.72 & 4.36 & 3.65 & 3.73 & 4.13 & 3.51 & 3.47 \\
\hline & \multicolumn{10}{|c|}{ Average Biomass Trials 1-3 } \\
\hline DMSO & 7.28 & 5.92 & 6.46 & 6.43 & 7.38 & 7.18 & 7.59 & 6.98 & 6.65 & 6.75 & 6.48 & 5.93 \\
\hline carolacton & 10.47 & 9.32 & 7.41 & 6.32 & 6.75 & 6.34 & 6.49 & 6.48 & 6.45 & 6.35 & 5.92 & 6.41 \\
\hline
\end{tabular}


Figure S3. Mutant Screen Results. S. mutans mutants were screened against analog $(+)-2$. Strains were screened in biological triplicate with compound and with the DMSO vehicle. The \% growth at $125 \mu \mathrm{L}$ for all 17 mutants is shown (bar graph). "\% growth" refers to (growth with compound/growth with vehicle*100). The table outlines the mutants that were used in the screen (provided by Robert Quivey, University of Rochester).
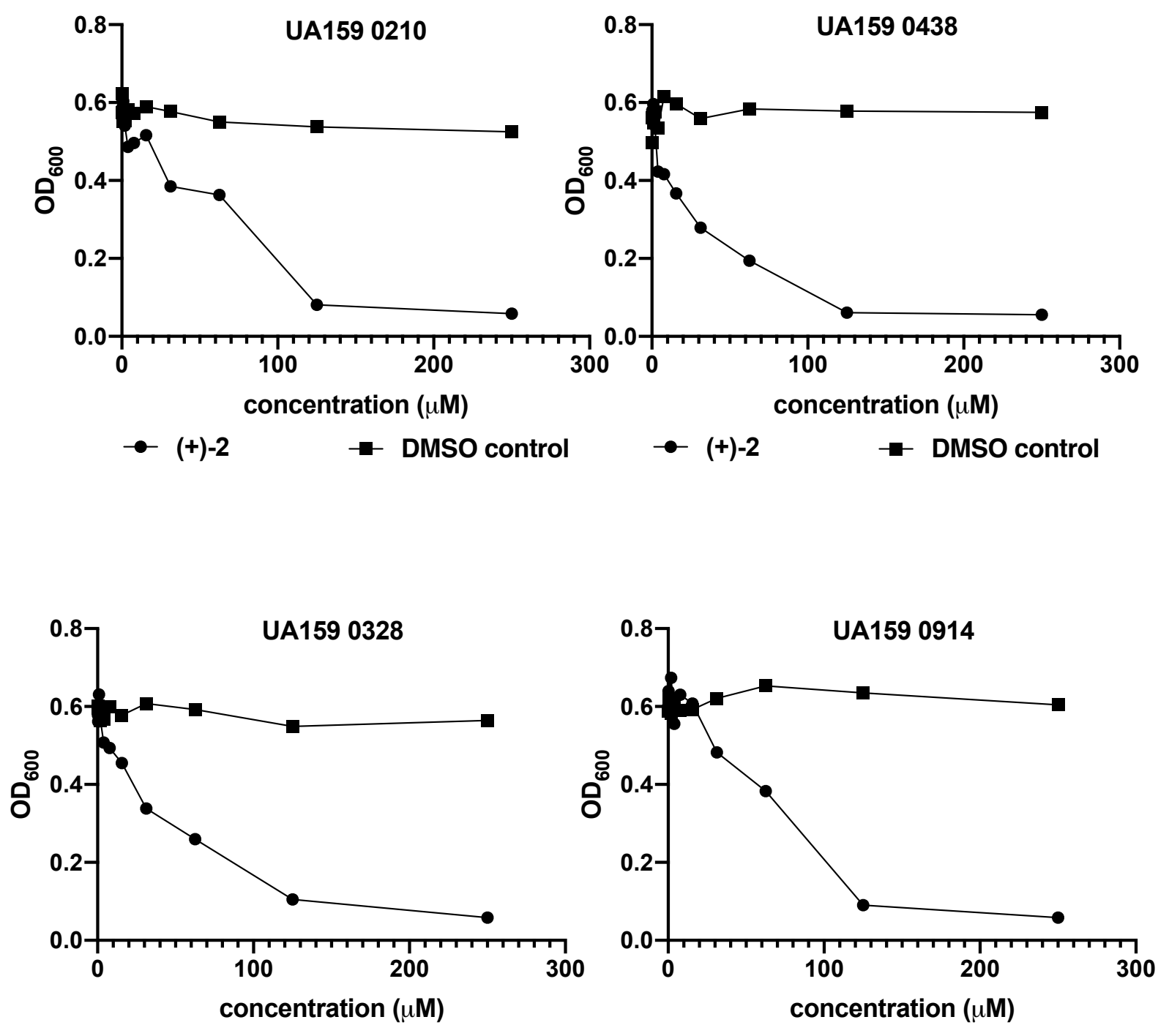
$(+)-2$
- DMSO control

$(+)-2$

DMSO control 

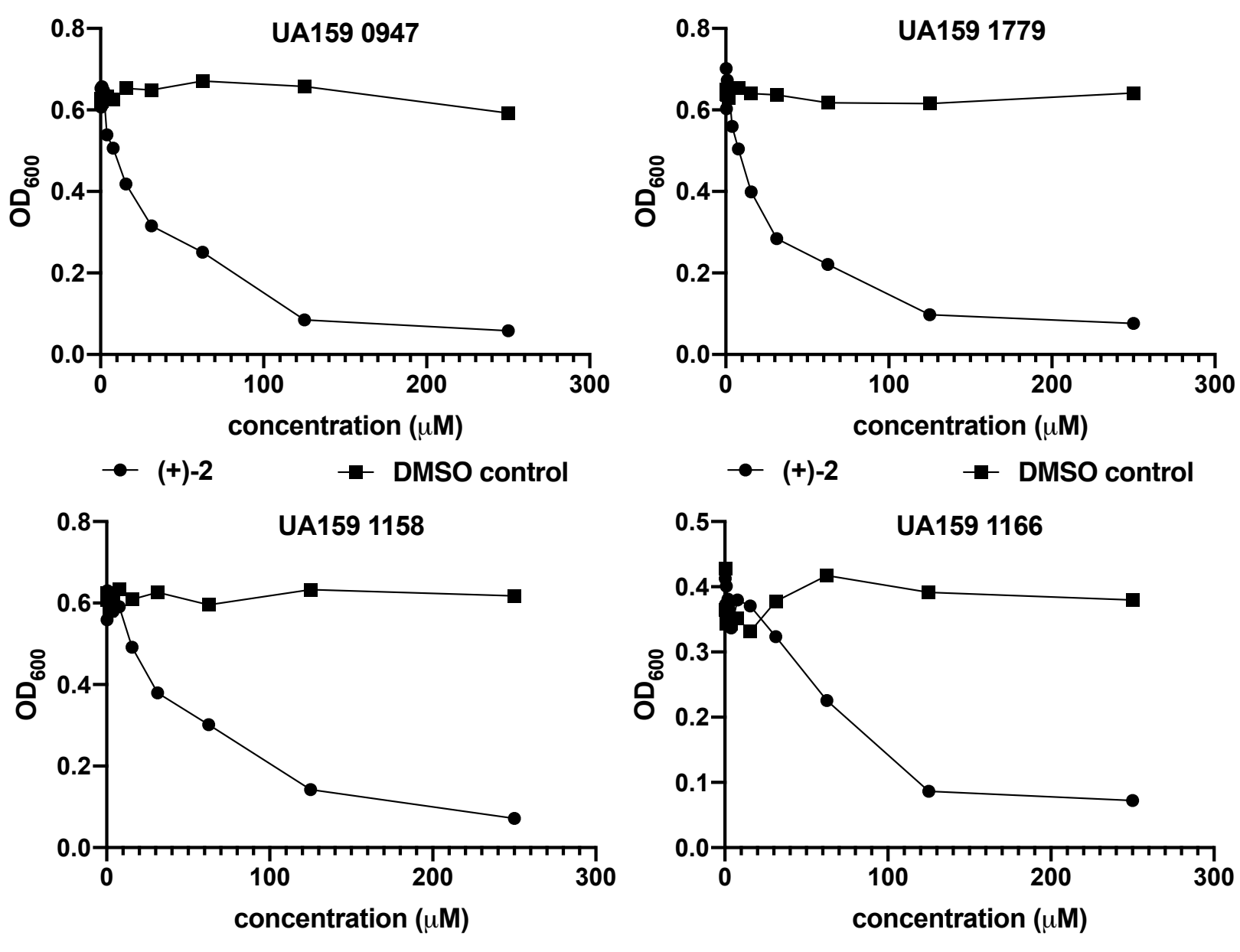

$\rightarrow(+)-2 \quad \rightarrow-$ DMSO control

$\rightarrow(+)-2 \quad \rightarrow$ DMSO control
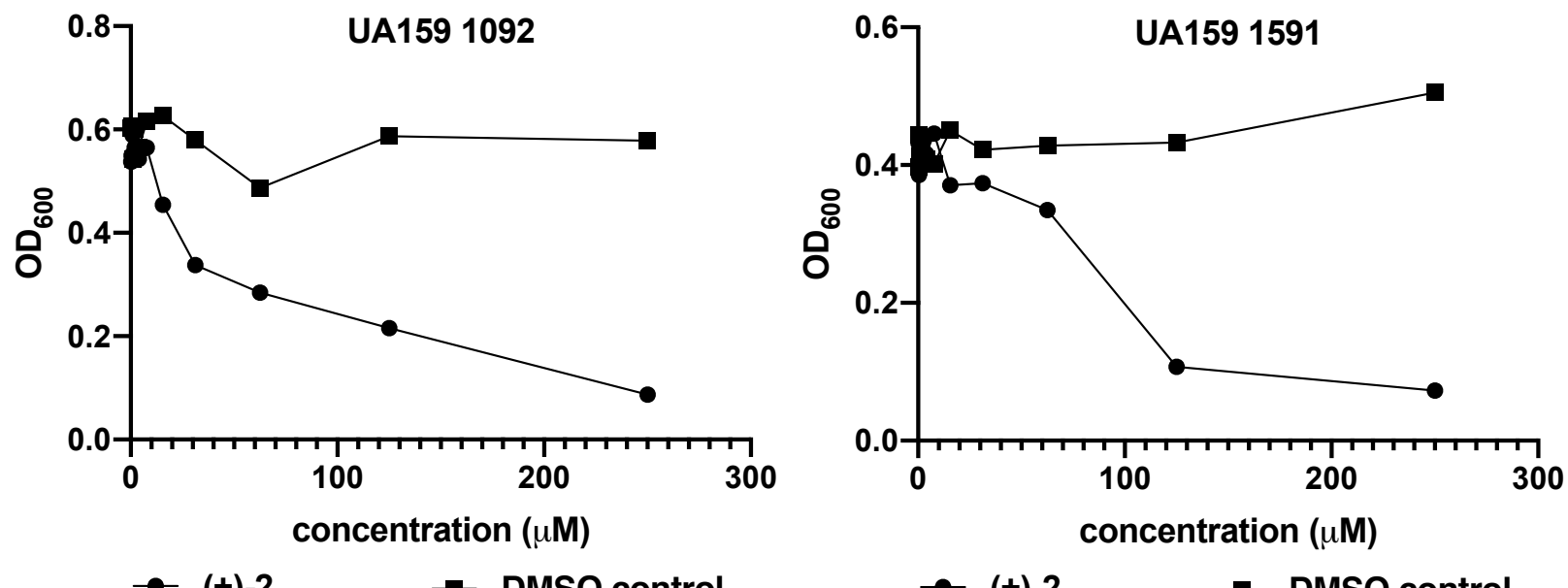


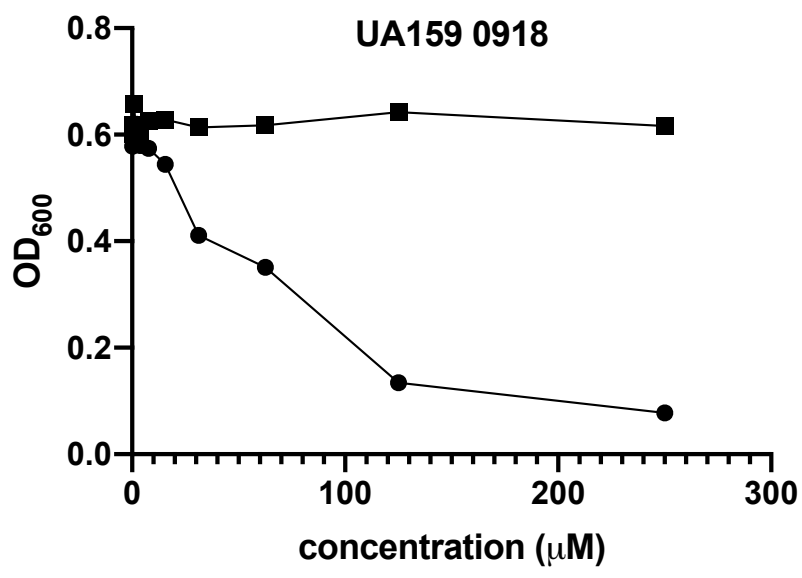

$\rightarrow(+)-2 \quad \rightarrow$ DMSO control

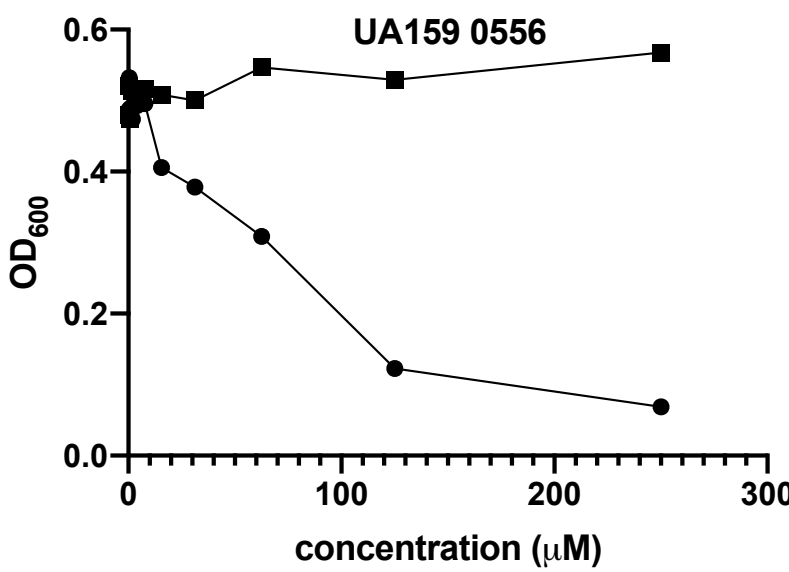

$\rightarrow(+)-2 \quad \rightarrow$ DMSO control

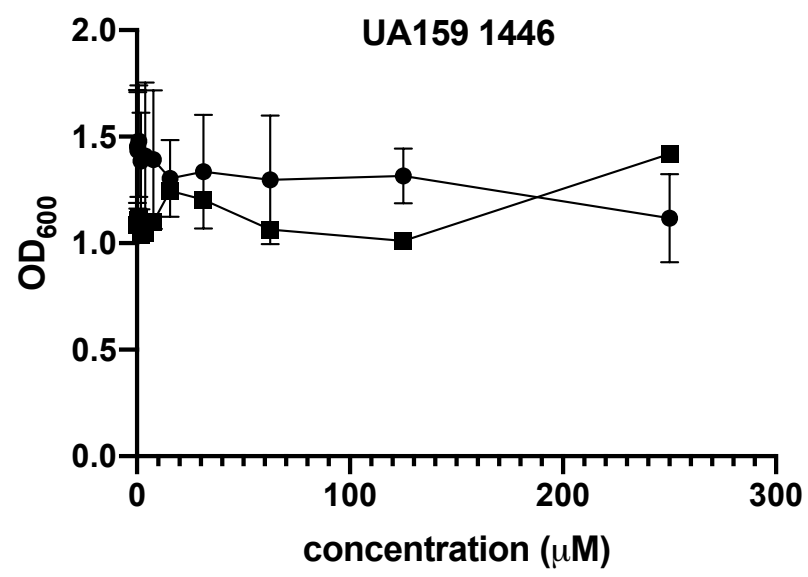

$(+)-2 \rightarrow-$ DMSO control

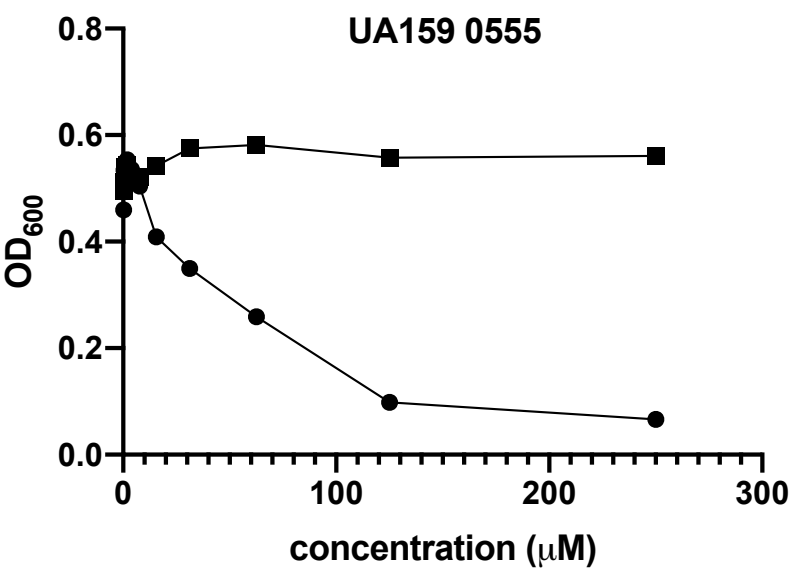

$\rightarrow(+)-2 \quad \rightarrow-$ DMSO control

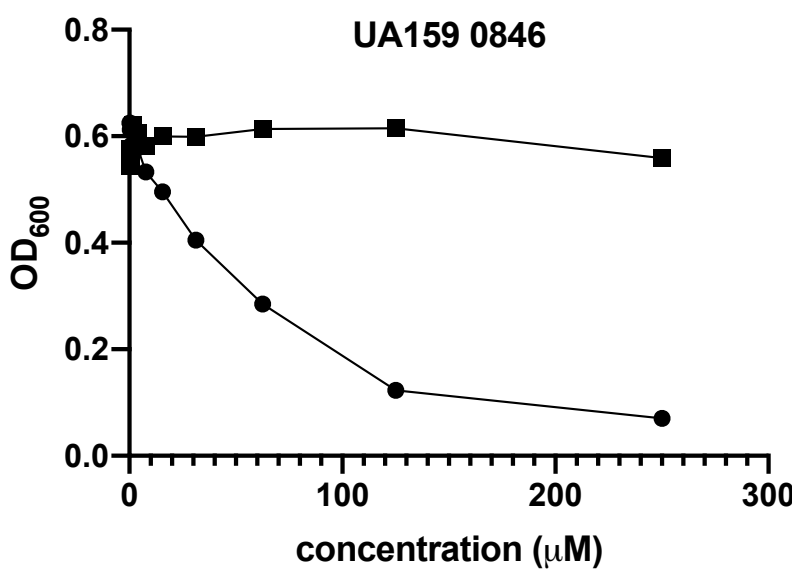

$\bullet(+)-2$

$\rightarrow$ DMSO control

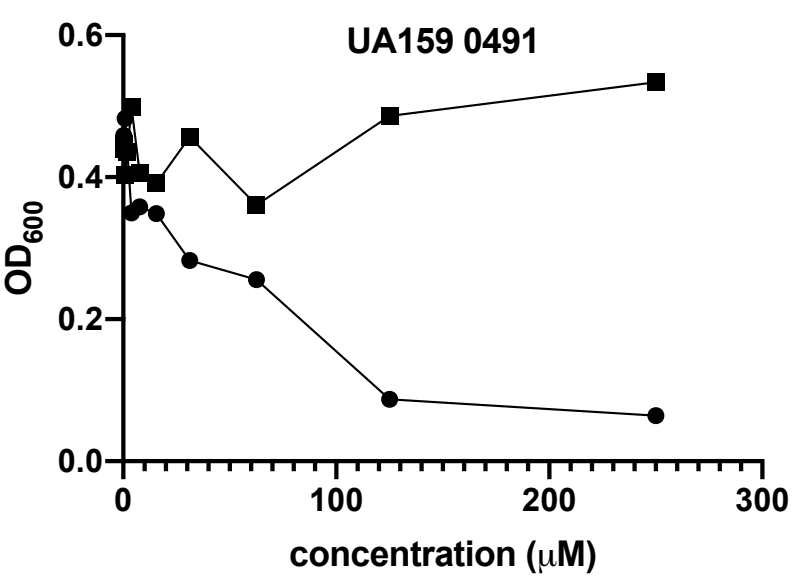

$(+)-2$
DMSO control 

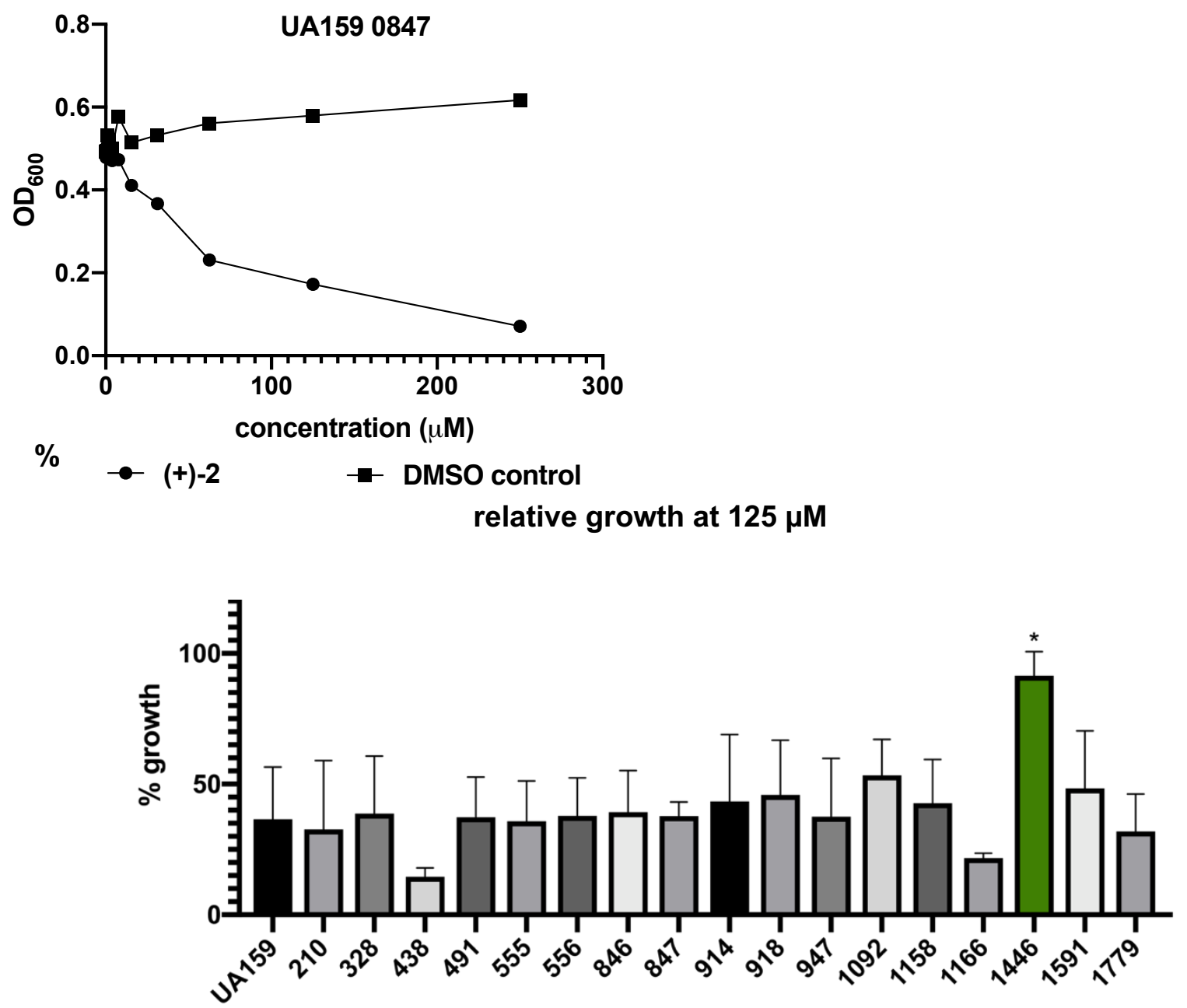

\section{S. mutans mutants}

\begin{tabular}{|c|c|c|c|}
\hline SMU Number & Origin Number & Gene & Description \\
\hline SMU.246 & UA159 0223 & rgpG & cell wall division; glycosyl transferase \\
\hline SMU.26 & UA159 0022 & plsX ylpD & putative fatty acid/phospholipid synthesis protein \\
\hline SMU.27 & UA159 0023 & ACP acpP & putative acyl carrier protein \\
\hline SMU.540 & UA159 0491 & dpr & peroxide resistance protein \\
\hline SMU.551 & UA159 0501 & ftsA & cell division \\
\hline SMU.610 & UA159 0556 & s-5 spaP sr (sc & cell surface antigen \\
\hline SMU.933 & UA159 0846 & atmA & putative amino acid ABC transporter; periplasmic amino acid \\
\hline SMU.934 & UA159 0847 & $?$ & putative amino acid ABC transporter; permease protein \\
\hline SMU.1266 & UA159 1158 & hisH & putative glutamine amido transferase \\
\hline SMU.1276c & UA159 1166 & ezrA & septation ring formation regulator \\
\hline SMU.1960c & UA159 1779 & levE & putative PTS system manose specific IIB component \\
\hline SMU.2007 & UA159 1823 & rl15 rplO & 50S ribosomal protein L!5 \\
\hline SMU.609 & UA159 0555 & bsp & putative 50K cell wall protein precursor; murein=peptidoglycase \\
\hline SMU.1004 & UA159 0914 & gttb & glucosyltransferase-I \\
\hline SMU.1193 & UA159 1092 & yhcF & putative transcriptional regulator; DNA interactions \\
\hline SMU.232 & UA159 0210 & ilvH & acetolactate synthase, small subunit; acetolate is made from pyruvic acid which is made from glucose...? \\
\hline SMU.1008 & UA159 0918 & IlrG & putative response regulator; two component system \\
\hline SMU.1591 & UA159 1446 & ccpA regM & catabolite control protein A, CcpA; DNA interactions; interacts with things that are produced with high levels of sugars \\
\hline SMU.1038c & UA159 0947 & vicR ycbL & putative response regulator; two component system \\
\hline SMU.363 & UA159 0328 & glnR & putative transcriptional regulator \\
\hline SMU.1745c & UA159 1591 & $?$ & transcriptional regulator glutamine synthetase repressons; Acid tolerance \\
\hline SMU.484 & UA159 0438 & pknB & putative serine/threonine protein kinase \\
\hline
\end{tabular}




\section{Supplemental IC $\mathrm{C}_{50}$ Curves}

All optical density (OD) measurements were performed on a Molecular Devices SpectraMax iD3 plate reader and growth was recorded by $\mathrm{OD}_{600}$. The dotted line refers to the average growth of bacterial strain in that growth condition. $I C_{50}$ curves were calculated with GraphPad Prism using a four-parameter nonlinear regression fit.

Bacteria: S. mutans Growth Conditions: THB Media Compound: carolacton

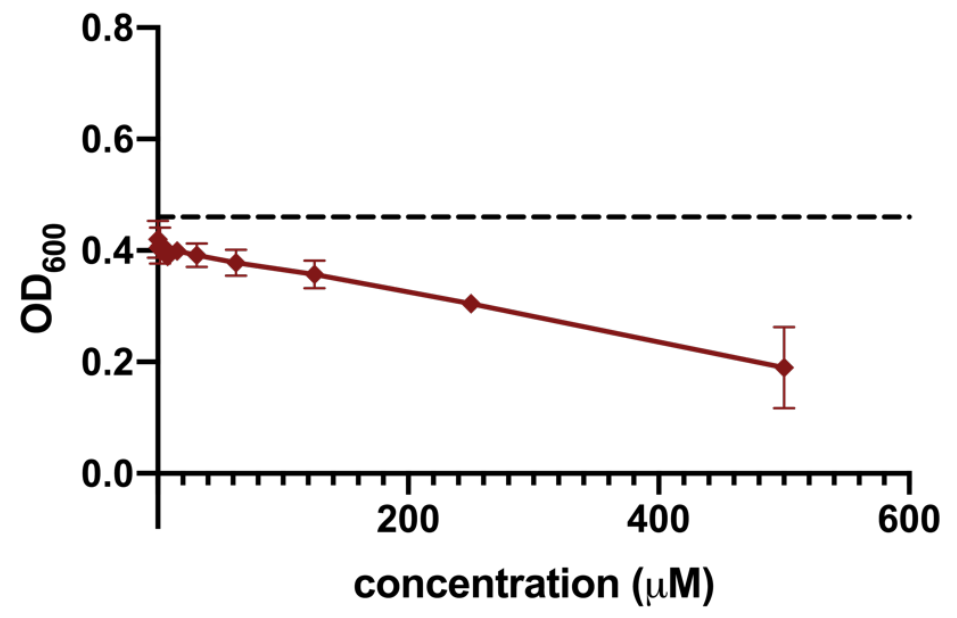

Bacteria: S. mutans Growth Conditions: THB Media Compound: C3

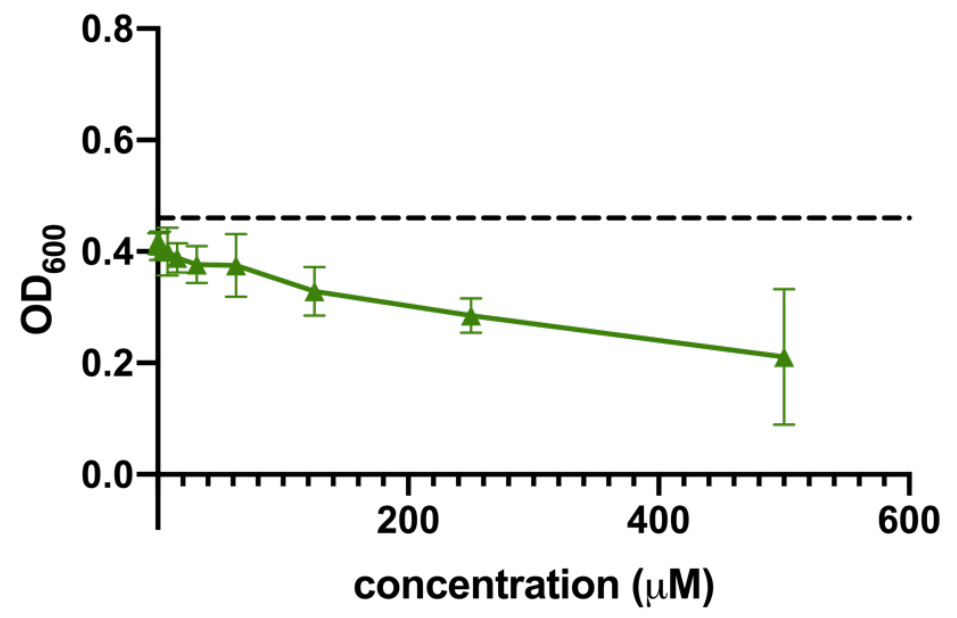


Bacteria: S. mutans Growth Conditions: THB Media Compound: (-)-9

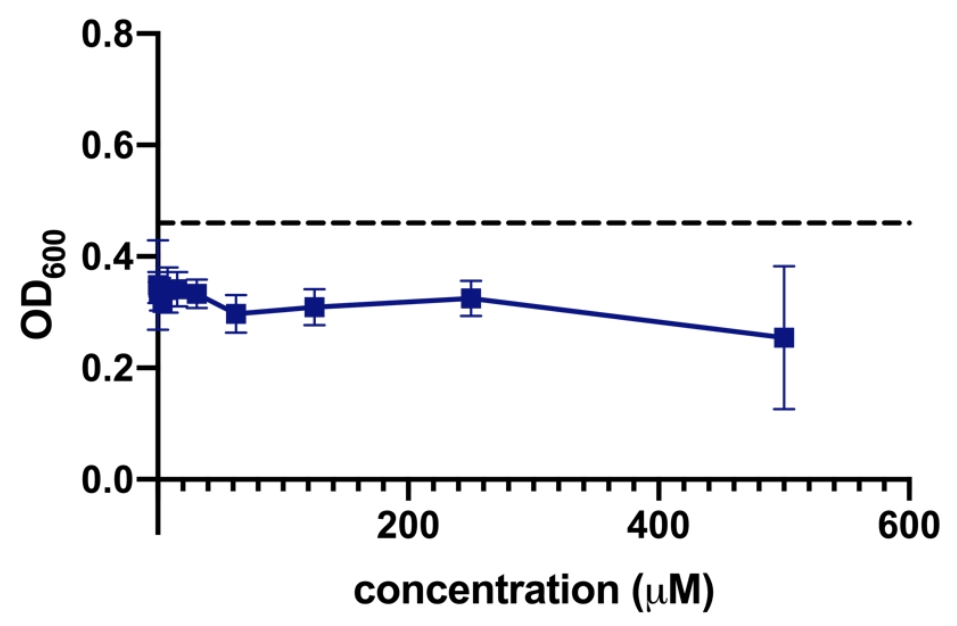

Bacteria: S. mutans Growth Conditions: THB Media Compound: (+)-10

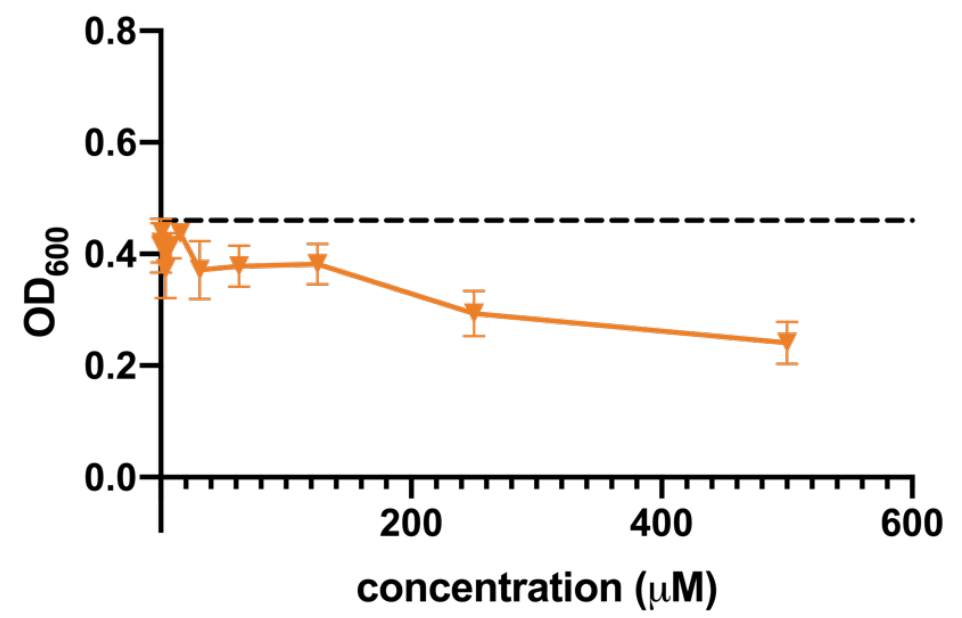

Bacteria: S. mutans Growth Conditions: THB Media Compound: (+)-2

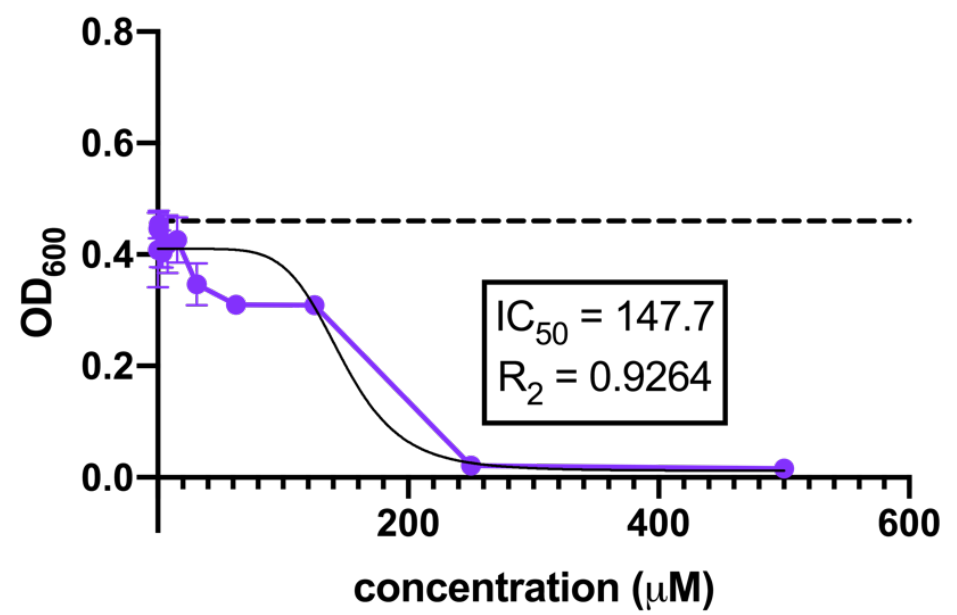


Bacteria: S. mutans Growth Conditions: THB Media + 0.1\% sucrose Compound: carolacton

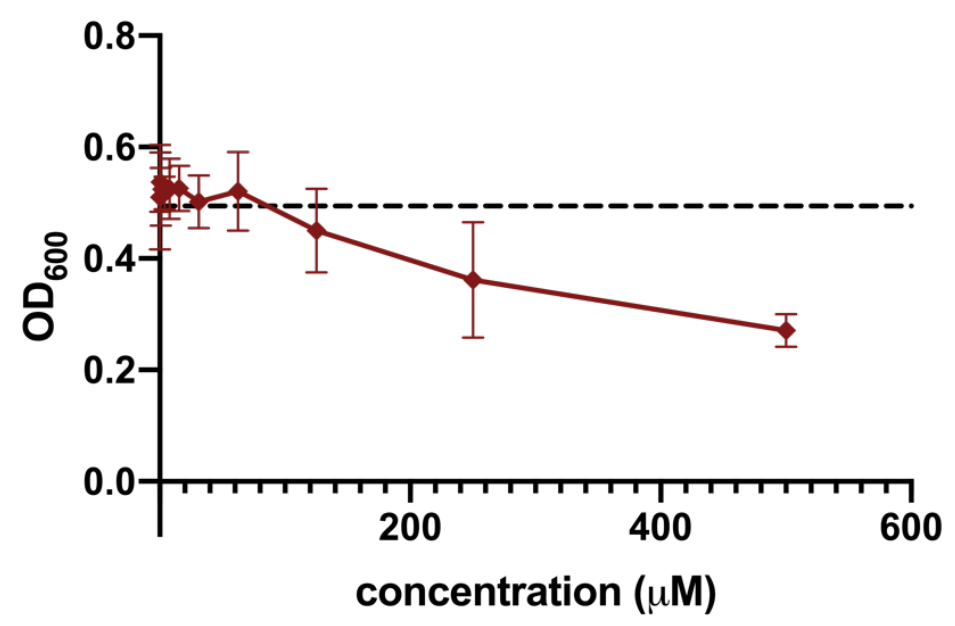

Bacteria: S. mutans Growth Conditions: THB Media + $0.1 \%$ sucrose Compound: C3

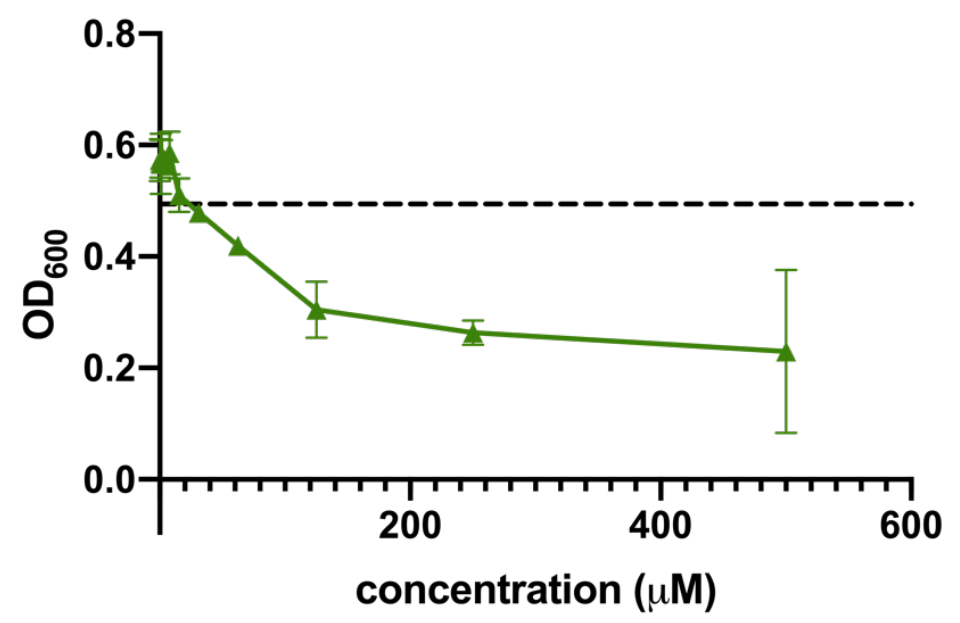

Bacteria: S. mutans Growth Conditions: THB Media + 0.1\% sucrose Compound: (-)-9

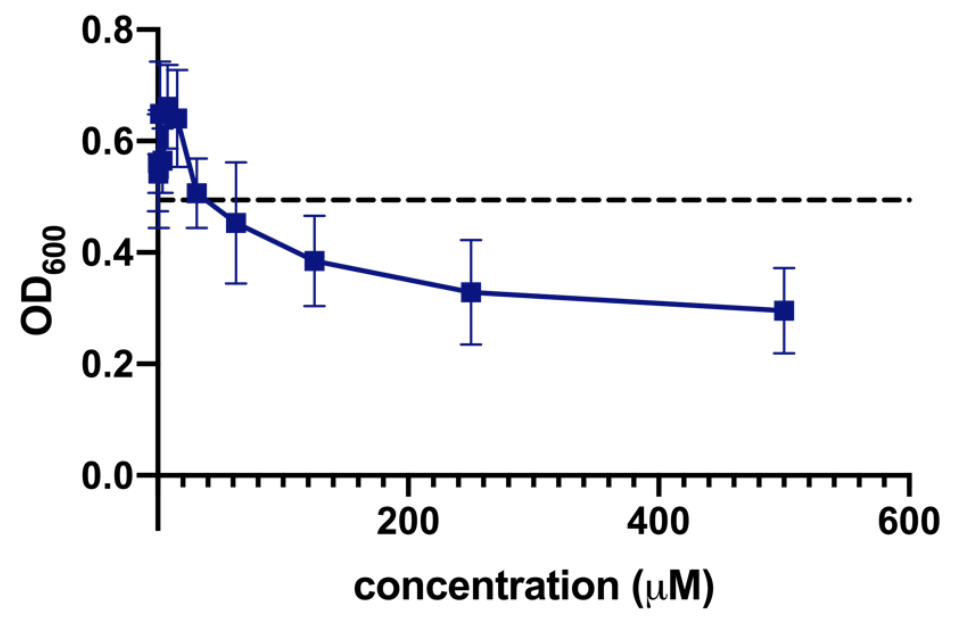


Bacteria: S. mutans Growth Conditions: THB Media $+0.1 \%$ sucrose Compound: $(+)-10$

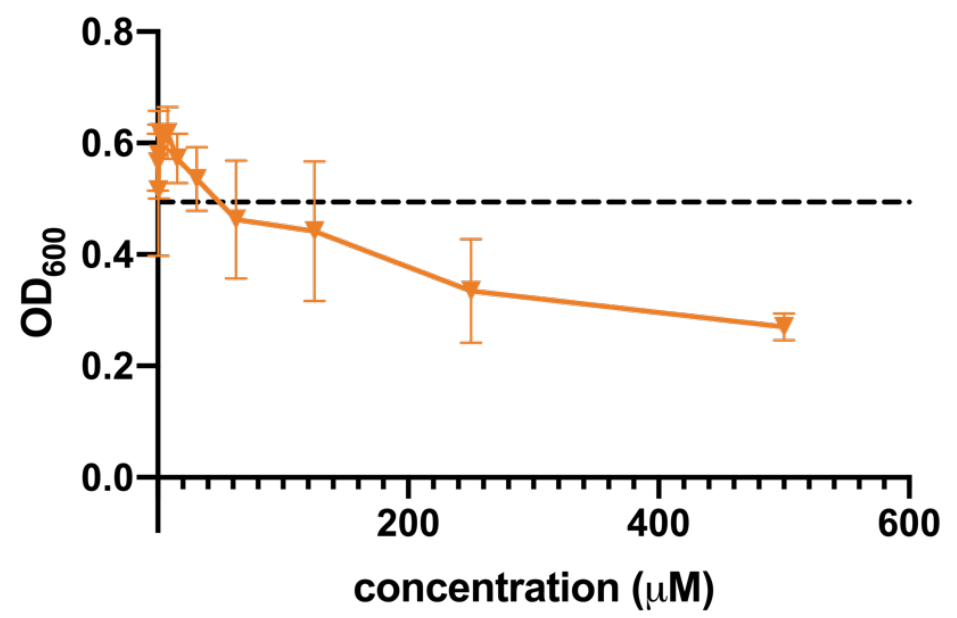

Bacteria: S. mutans Growth Conditions: THB Media + 0.1\% sucrose Compound: (+)-2

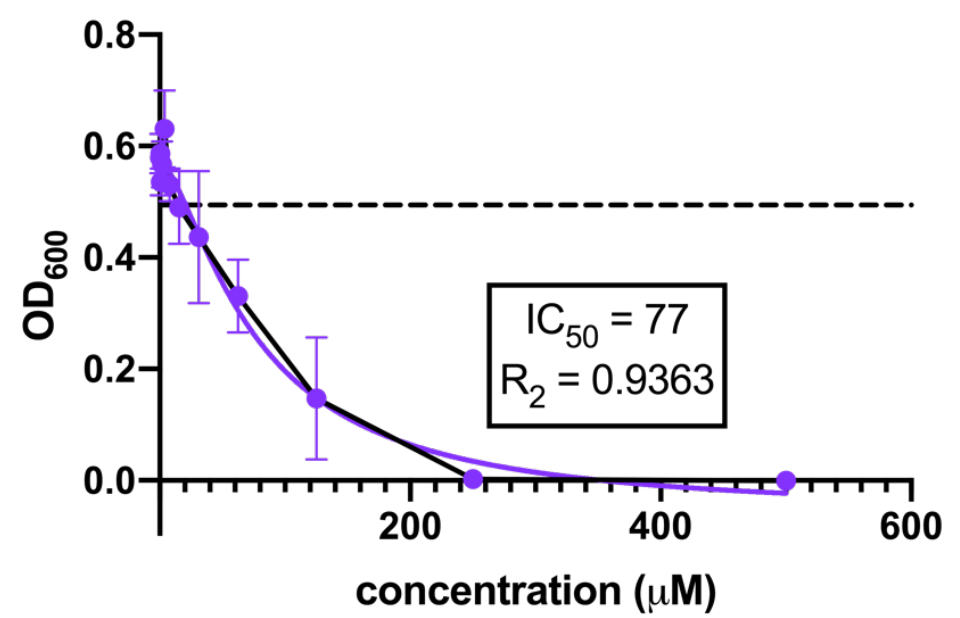

Bacteria: S. mutans Growth Conditions: THB $+0.1 \%$ sucrose + glass bottom 96 -well plate Compound: carolacton

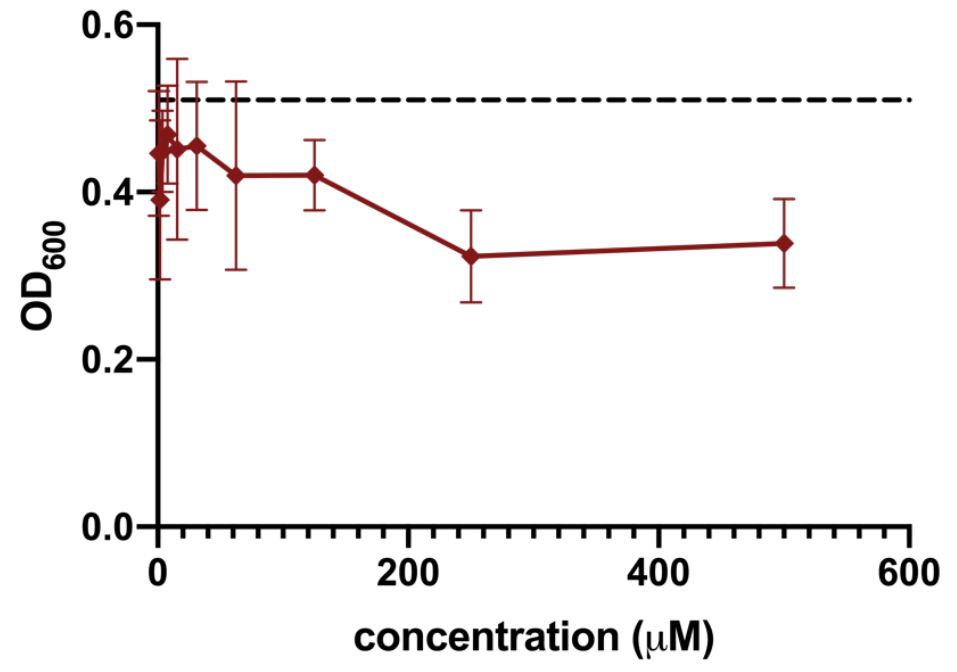


Bacteria: S. mutans Growth Conditions: THB $+0.1 \%$ sucrose + glass bottom $96-$ well plate Compound: (-)-9

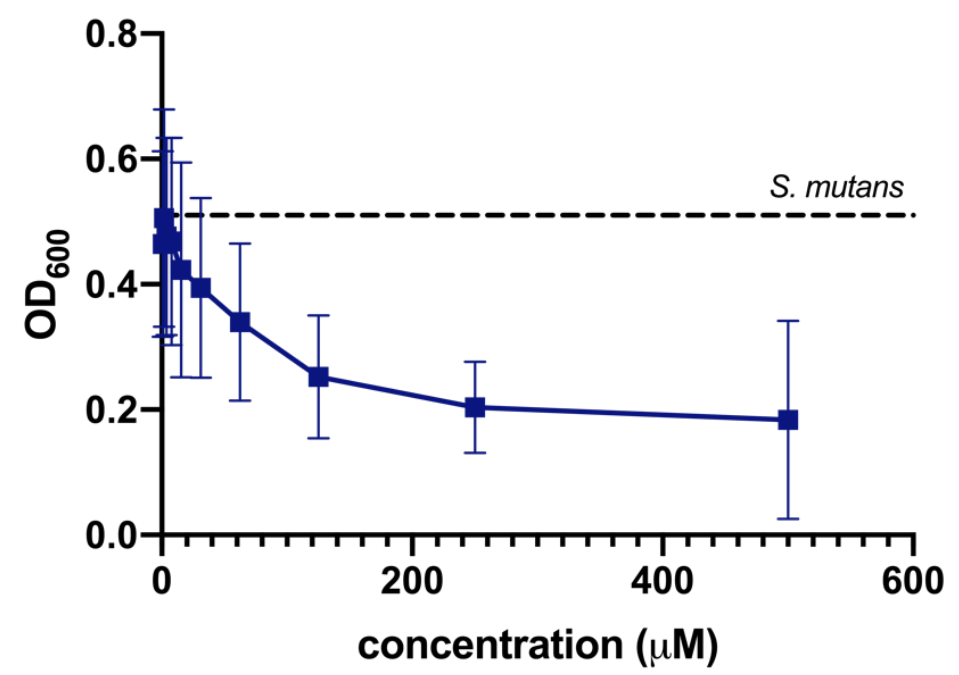

Bacteria: S. mutans Growth Conditions: THB $+0.1 \%$ sucrose + glass bottom $96-$ well plate Compound: $(+)-10$

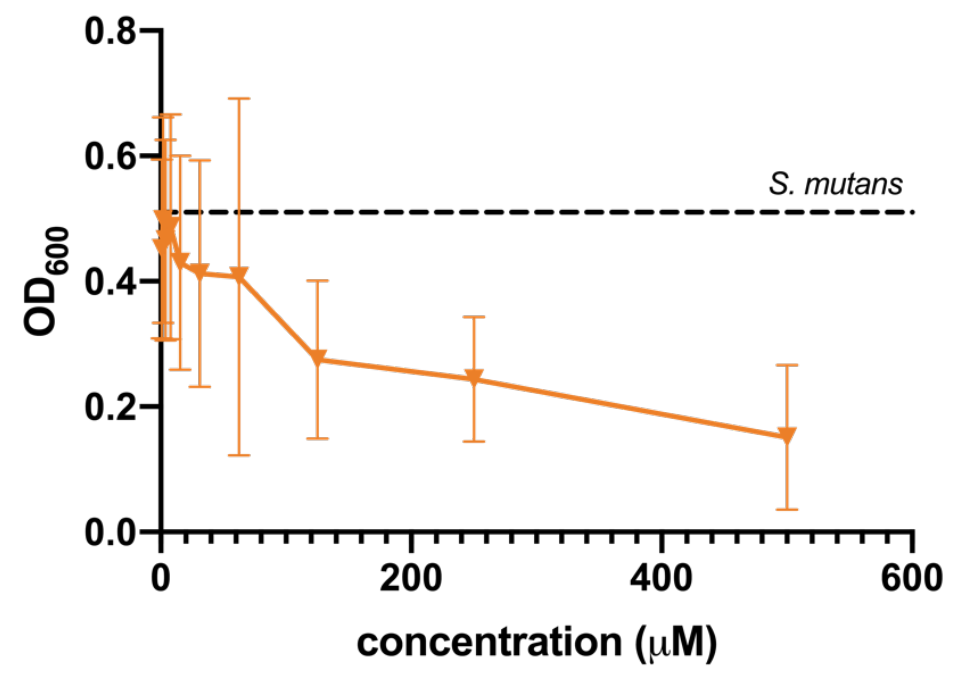


Bacteria: S. mutans Growth Conditions: THB $+0.1 \%$ sucrose + glass bottom $96-w e l l$ plate Compound: (+)-2

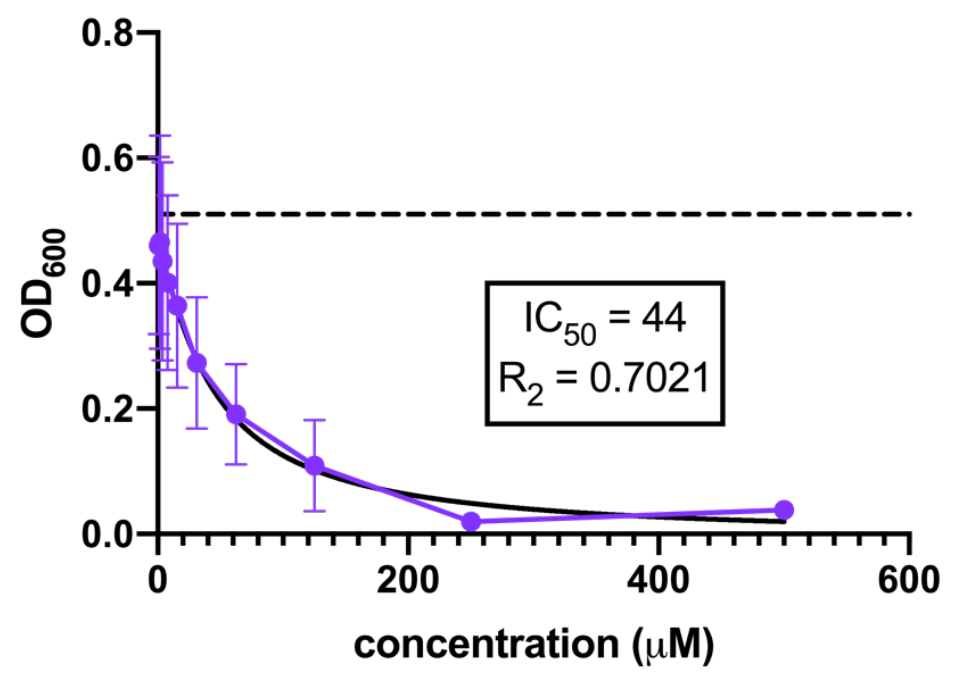

Bacteria: S. mutans Growth Conditions: THB; pH 5 Compound: (+)-2

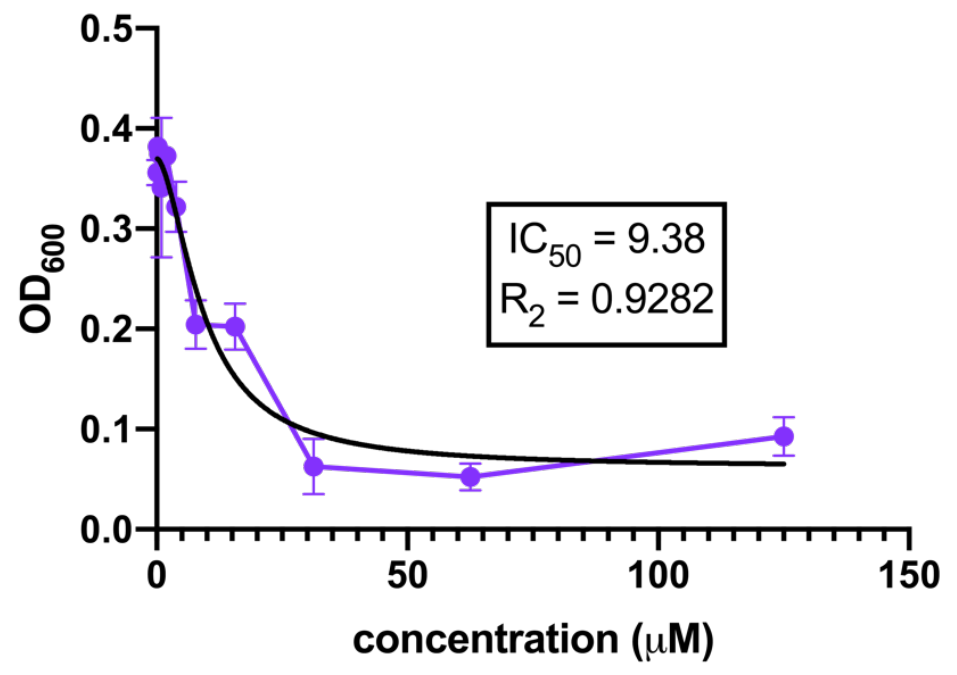


Bacteria: S. gordonii Growth Conditions: THB Compound: (+)-2

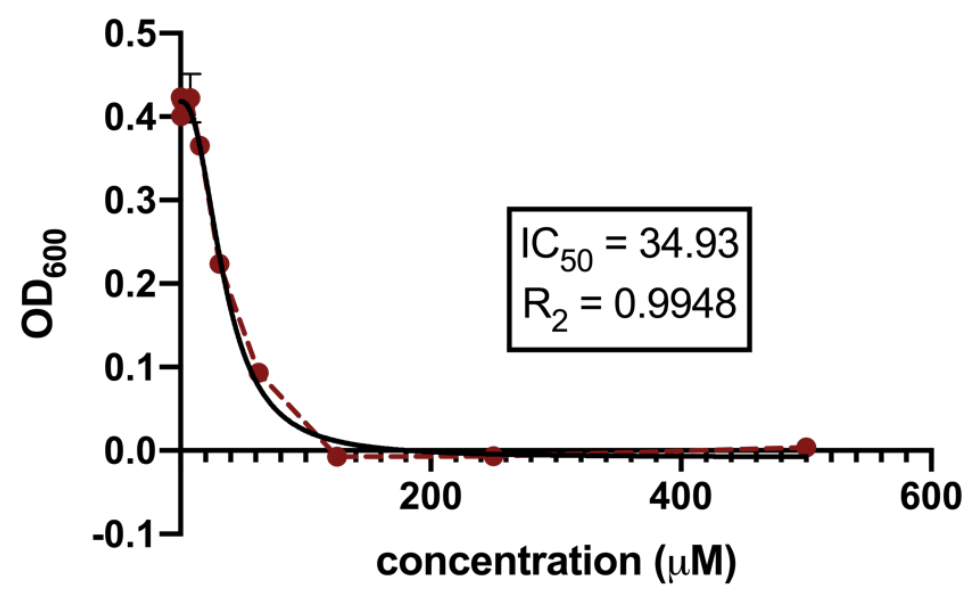

Bacteria: S. gordonii Growth Conditions: THB $+0.1 \%$ sucrose Compound: (+)-2

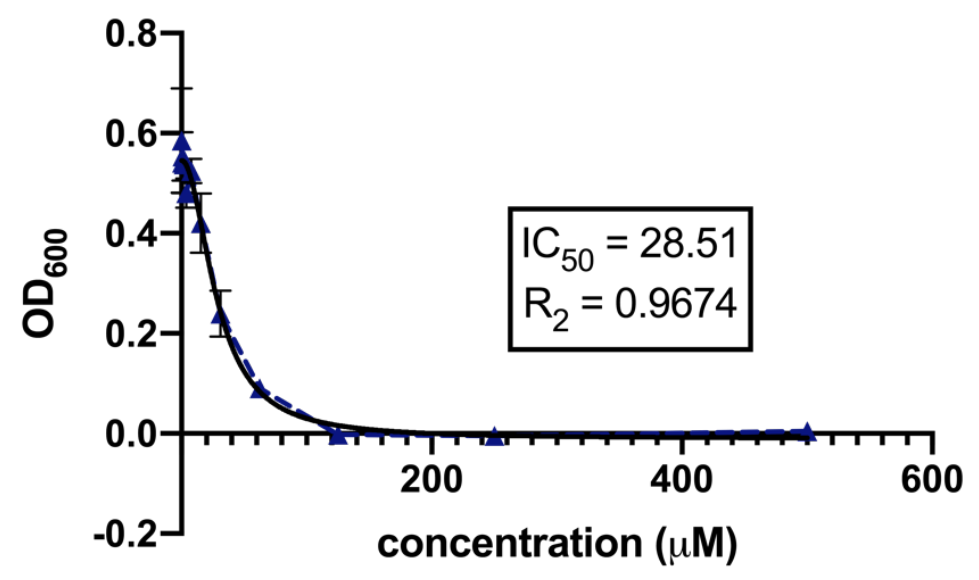




\section{Biological Procedures}

Materials. Streptococcus mutans wild-type strain UA159 was used for all bacterial cultures and was provided by Dr. Bettina Buttaro from Temple University Medical School, Philadelphia, PA. Bacteria were routinely maintained in BactoTM Todd-Hewitt (TH) agar plates and liquid cultures were grown in in BactoTM Todd-Hewitt broth (THB). For growth of biofilms, THB was supplemented with $0.1 \%$ sucrose. Incubation was stagnant at $37^{\circ} \mathrm{C}$. S. mutans mutants were provided by Dr. Robert G. Quivey from the Department of Microbiology and Immunology of University of Rochester. Bacterial mutants were maintained in BactoTM Todd-Hewitt broth supplemented with erythromycin. All optical density (OD) measurements were performed on a Molecular Devices SpectraMax iD3 plate reader.

S. mutans MIC assay. Stock solution of carolacton analogs, 10,000 $\mu \mathrm{M}$ in DMSO, were serial diluted in THB media in flat-bottom 96 -well microtiter plates. Mid-exponential phase cell culture was diluted to an $\mathrm{OD}_{600}$ of 0.004 and added to the serial diluted compound to reach a final volume of $200 \mu \mathrm{L}$. Plates are incubated at $37^{\circ} \mathrm{C}$ in $5 \% \mathrm{CO}_{2}$ for $20-24$ hours upon which time wells are evaluated visually for bacterial growth and the $\mathrm{OD}_{600}$ was recorded with the plate reader. The MIC is determined as the lowest concentration of compound resulting in no bacterial growth visible to the naked eye. The $\mathrm{IC}_{50}$ is the concentration of compound needed for $50 \%$ growth inhibition. Biological triplicates were performed in three separate experiments to confirm results.

Compound treated S. mutans biofilm preparation model. Stock solution of carolacton analogs, $10,000 \mu \mathrm{M}$, were serial diluted in THB media with $0.1 \%$ sucrose $(\mathrm{w} / \mathrm{v})$ in glass flat-bottom 96-well microtiter plates. Mid-exponential phase cell culture was diluted to an $\mathrm{OD}_{600}$ of 0.004 and added to the serial diluted compound to reach final volume of $200 \mu \mathrm{L}$. Plates were incubated at $37{ }^{\circ} \mathrm{C}$ in $5 \% \mathrm{CO}_{2}$ for $24-28$ hours (early stage biofilm) at which time wells were evaluated visually for bacterial growth. $\mathrm{OD}_{600}$ measurements of growth was performed after visual inspection. Biological triplicates were performed in three separate experiments to confirm results. 
Colony-Forming Units Assay Compound treated S. mutans biofilms were prepared as described above. Plates were incubated at $37{ }^{\circ} \mathrm{C}$ in $5 \% \mathrm{CO}_{2}$ for 28 hours (early stage biofilm) at which time wells were evaluated visually for bacterial growth. $\mathrm{OD}_{600}$ measurements of growth was performed after visual inspection, and then emptied by inverting carefully, as to not disturb the biofilm. Wells were washed with $200 \mu \mathrm{L}$ of phosphate buffer solution (PBS) or THB media to remove planktonic cells three times. Following the washes, $200 \mu \mathrm{L}$ of PBS or THB were added, and the biofilm cells were resuspended. Then, the biofilm suspensions were diluted in PBS or THB, in log fashion, and plated on THB agar plates. Plates were incubated for 24-48 hours and colonies were counted.

S. mutans mutant screen Stock solution of (-)-2, 10,000 $\mu \mathrm{M}$, were serial diluted in THB media with $0.1 \%$ sucrose $(\mathrm{w} / \mathrm{v})$ in glass flat-bottom 96 -well microtiter plates. Each mutant was grown with compound, and separately with the DMSO vehicle. Mid-exponential phase cell culture was diluted to an $\mathrm{OD}_{600}$ of 0.004 and added to the serial diluted compound or DMSO control to reach final volume of $200 \mu \mathrm{L}$. Plates were incubated at 37 ${ }^{\circ} \mathrm{C}$ in $5 \% \mathrm{CO}_{2}$ for 24 hours (early stage biofilm) at which time wells were evaluated visually for bacterial growth. $\mathrm{OD}_{600}$ measurements of growth was performed after visual inspection.

S. mutans $\mathrm{MBIC}_{50}$ assay. Biofilms were prepared with above procedure, evaluated visually, $\mathrm{OD}_{600}$ of bacterial growth was recorded, and then emptied by inverting carefully, as to not disturb the biofilm. Wells were washed with $200 \mu \mathrm{L}$ of phosphate buffer solution (PBS) and dried overnight at $37^{\circ} \mathrm{C}$. Once dry, plates were incubated for $10 \mathrm{~min}$ at room temperature with $200 \mu \mathrm{L}$ of $1 \% \mathrm{w} / \mathrm{v}$ crystal violet in $\mathrm{DI}_{2} \mathrm{O}$. Excess crystal violet was removed by aspirating off the liquid and performing $\mathrm{DI} \mathrm{H}_{2} \mathrm{O}$ rinses until the run off was colorless. Plates were then inverted and dried overnight at $37^{\circ} \mathrm{C}$. Crystal violet stained biofilm was dissolved with $200 \mu \mathrm{L}$ of $10 \%$ acetic acid in $\mathrm{DI} \mathrm{H}_{2} \mathrm{O}$. The crystal violet plate with acetic acid solution was allowed to incubate at room temperature for 10-30 minutes to allow for full dissolution. Then $100 \mu \mathrm{L}$ was transferred to a fresh flat-bottom 96-well plate for absorbance measurements at $595 \mathrm{~nm}$. DMSO controls corresponding to each test concentration were performed. Crystal violet reading was set relative to bacterial 
growth $\left(\mathrm{OD}_{595} / \mathrm{OD}_{600}\right)$ to allow for appropriate comparison of biofilm mass formation. $\mathrm{MBIC}_{50}$ refers to the concentration at which biofilm growth is inhibited by $50 \%$ compared to the control. Biological triplicates were performed in three separate experiments to confirm results.

Confocal Imaging. Biofilms were prepared with above procedure. In order to perform efficient imaging, uncoated 96-Well Plates with $5 \mathrm{~mm}$ Glass Diameter from MatTek (Part No: P96G-0-5-F) were used for confocal imaging experiments. After incubation, media was removed, and each well was carefully rinsed three times with PBS to remove planktonic cells. Subsequently, $20 \mu \mathrm{L}$ of BacLight LIVE/DEAD ${ }^{\mathrm{TM}}$ stain was added to each well. Excess dye was rinsed off biofilm with PBS. Images of biofilms were then obtained using the Olympus FV1000 inverted microscope in the Integrated Cellular Imaging Core at Emory University. 


\section{Experimental Procedures}

General. NMR spectra were recorded using the following spectrometers: Varian INOVA 600, INOVA 500, INOVA 400, VNMR 400, Mercury 300, Bruker AVANCE III HD 600, Bruker NANO HD III 400, Bruker AVANCE 600 WB SSNMR and Bruker AVANCE III 300 WB SSNMR. Chemical shifts are reported in ppm relative to tetramethylsilane and with the indicated solvent as an internal reference. The following abbreviations are used to describe signal multiplicities: s (singlet), $d$ (doublet), $t$ (triplet), $q$ (quartet), $m$ (multiplet), br (broad), dd (doublet of doublets), dt (doublet of triplets), etc. Accurate mass spectra were recorded on a Thermo LTQ FTMS, infrared spectra were obtained using a Thermo Scientific Nicolet iS10 Smart Orbit FT-IR spectrophotometer and specific rotation measurements were collected using a $1 \mathrm{dm}$ path length using a Perkin Elmer 341 Polarimeter. Non-aqueous reactions were performed under an atmosphere of argon, in flame-dried glassware, with HPLC-grade solvents dried by passage through activated alumina. Amine bases were freshly distilled from $\mathrm{CaH}_{2}$ prior to use. Brine refers to a saturated aqueous solution of sodium chloride. Products purified via flash chromatography using Biotage Isolera One Automated column. Reactions monitored via thin-layer chromatography (TLC) using EMD Millipore ${ }^{\circledR}$ TLC silica gel glass plates with $\mathrm{KMnO}_{4}$ stain. All products were observed as clear, colorless or slightly tinted yellow oils.

\section{Representative Procedure A: Parikh-Doering Oxidation}

A flame dried flask was charged with the monoprotected diol starting material and DCM. Dimethyl sulfoxide and then triethylamine were then added to the reaction mixture. The reaction was then cooled to $0{ }^{\circ} \mathrm{C} . \mathrm{SO}_{3} \cdot$ pyridine was added and the reaction was allowed to warm to room temperature. After 1 hour of stirring at room temperature, the reaction mixture was diluted with DCM and then quenched with saturated aqueous solution of ammonium chloride. After separation, the aqueous layer was extracted with ethyl acetate (x3). The combined organics were rinsed with brine (x2), dried over $\mathrm{MgSO}_{4}$, filtered and concentrated.

\section{Representative Procedure B: Roush Crotylation}

A flask was charged with a stir bar and powdered $4 \AA$ mol sieves and was then flame dried. A solution of $E$-crotylboronate in toluene (prepared via literature procedure) ${ }^{1}$ was added, followed by additional toluene. The solution was cooled to $-78{ }^{\circ} \mathrm{C}$. The aldehyde 
(3a/3b) was added as a solution in toluene, slowly via syringe pump over $\sim 20$ minutes. The reaction was stirred for 3 hours at this temperature. $\mathrm{NaOH}$ was then added and the reaction was transferred to a $0{ }^{\circ} \mathrm{C}$ cooling bath and stirred for 20 minutes. The reaction was filtered through a pad of celite. The organic layer was separated, and the aqueous layer was extracted with diethyl ether $(x 4)$. The combined organic layers were washed with $\mathrm{H}_{2} \mathrm{O}$ and brine, dried over sodium sulfate, filtered, and concentrated. The product was obtained as a single diastereomer as determined by ${ }^{1} \mathrm{HNMR}$.

\section{Representative Procedure C: EDC Esterification}

A flame dried flask was charged with argon, the carboxylic acid starting material and DCM. The reaction was subsequently cooled to $0^{\circ} \mathrm{C}$, then DMAP and EDC were added consecutively. After 10 minutes, a solution of the alcohol (4a/4b) in DCM was added via syringe pump. The reaction was stirred 24-30 hours depending on TLC analysis and then added to a separatory funnel containing equal volume of $\mathrm{H}_{2} \mathrm{O}$. The organic layer was separated, and the aqueous layer was extracted with DCM $(3 \times 15 \mathrm{~mL})$. The combined organic layers were washed with brine, dried over $\mathrm{MgSO}_{4}$, filtered and concentrated.

\section{Representative Procedure D: Ring-Closing Metathesis}

A flask was charged with the alkene starting material (5a/5b) and DCM. Grubbs II generation catalyst was added, and the reaction was stirred at room temperature for 24 hours. The solvent was removed. NOTE: In our experience, adding a second equivalent of catalyst $\sim 6$ hours after start helps with starting material consumption.

\section{Representative Procedure E: TBS removal}

To a solution of protected macrocycle $(6 \mathrm{a} / 6 \mathrm{~b})$ in THF, was added tetra-butylammonium fluoride (1M in THF). The reaction was stirred for 1 hour. The reaction was quenched with saturated aqueous ammonium chloride and diluted in diethyl ether. The organic layer was separated, and the aqueous layer was extracted with diethyl ether (x4). The combined organic layers were washed with water and brine, dried over sodium sulfate, filtered, and concentrated. 


\section{Representative Procedure F: TEMPO Oxidation}

A vial was charged with deprotected macrocycle (7a/7b/10a), acetonitrile, TEMPO, and sodium phosphate buffer $(0.67 \mathrm{M}, \mathrm{pH} 6.7)$. The reaction was warmed to $35^{\circ} \mathrm{C}$ and stirred for 30 minutes. Then aqueous solutions of bleach and sodium chlorite were added to the reaction drop wise over 30 minutes. Reaction was stirred at $35^{\circ} \mathrm{C}$ for 24 hours at which time it was quenched with aqueous thiosulfate solution. The aqueous layer was extracted once with ethyl acetate (first ethyl acetate layer set aside). Then the aqueous layer was acidified to $\sim \mathrm{pH} 4$ and extracted with ethyl acetate $(x 3)$. The organics were washed with brine, dried over $\mathrm{MgSO}_{4}$, filtered and concentrated.

\section{Representative Procedure G: Acetonide Deprotection}

To a solution of carboxylic acid macrocycle (8a/8b) in THF was added HF pyridine and $\mathrm{H}_{2} \mathrm{O}$. The mixture was stirred for 4-6 hours and then quenched with $1 \mathrm{M} \mathrm{NaOH}$. The aqueous layer was acidified to $\sim \mathrm{pH} 4$ and then the product was extracted with ethyl acetate (x3), washed with brine, dried over $\mathrm{MgSO}_{4}$, filtered and concentrated.

\section{Representative Procedure H: Hydrogenation}

A vial was charged with deprotected macrocycle (7a), 1:1 Ethyl Acetate:Ethanol and 10\% $\mathrm{Pd} / \mathrm{C}$. Using a balloon, the vial was purged multiple times with $\mathrm{H}_{2}$. Full hydrogenation was realized after 4 hours at which point the reaction mixture was poured over celite and condensed. 


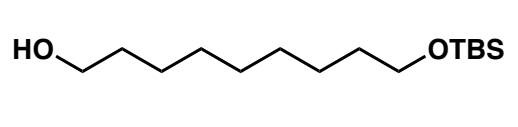

4

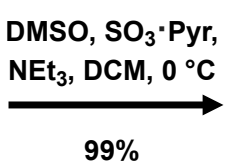

$99 \%$

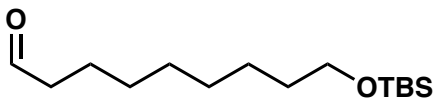

4b

9-((tert-butyldimethylsilyl)oxy)nonanal (4b) was synthesized according to Representative Procedure A: 9-((tert-butyldimethylsilyl)oxy)nonan-1-ol $(0.76 \mathrm{~g}, 2.78 \mathrm{mmol})$, dimethyl sulfoxide $(4.0 \mathrm{~mL}, 55.55 \mathrm{mmol})$, sulfur trioxide pyridine complex $(3.54 \mathrm{~g}, 22.22 \mathrm{mmol})$, triethylamine $(3.9$ $\mathrm{mL}, 27.78 \mathrm{mmol})$ in DCM $(28 \mathrm{~mL})$ yielded $0.75 \mathrm{~g}$ of $3 \mathbf{a}(99 \%$ yield $)$. Purified by column chromatography (0 to $10 \%$ EtOAc:Hexanes). $\mathbf{R}_{\boldsymbol{f}}=0.79$ (10\% EtOAc:Hexanes). ${ }^{1} \mathbf{H}$ NMR (500 $\left.\mathrm{MHz} \mathrm{CDCl}_{3}\right) \delta 9.76(\mathrm{t}, J=1.8 \mathrm{~Hz}, 1 \mathrm{H}), 3.59(\mathrm{t}, J=6.6 \mathrm{~Hz}, 2 \mathrm{H}), 2.42(\mathrm{td}, J=7.4,1.9 \mathrm{~Hz}, 2 \mathrm{H}), 1.62(\mathrm{p}$, $J=7.4 \mathrm{~Hz}, 2 \mathrm{H}), 1.54-1.47(\mathrm{~m}, 2 \mathrm{H}), 1.33-1.26(\mathrm{~m}, 9 \mathrm{H}), 0.89(\mathrm{~s}, 9 \mathrm{H}), 0.04(\mathrm{~s}, 6 \mathrm{H}) .{ }^{13} \mathrm{C}$ NMR $(126$ $\left.\mathrm{MHz}, \mathrm{CDCl}_{3}\right) \delta 203.29,63.66,44.32,33.23,29.74,29.62,29.52,26.39,26.14,22.48,18.79$, 4.85. HRMS (ES ${ }^{+}$): Found $273.22469(0.94 \mathrm{ppm}), \mathrm{C}_{15} \mathrm{H}_{32} \mathrm{O}_{2} \mathrm{Si}\left(\mathrm{M}+\mathrm{H}^{+}\right)$requires 273.22443. IR $2929.02(\mathrm{C}-\mathrm{H}), 1724.10(\mathrm{CHO}), 1463.11,1264.73,1093.86 \mathrm{~cm}^{-1}$.
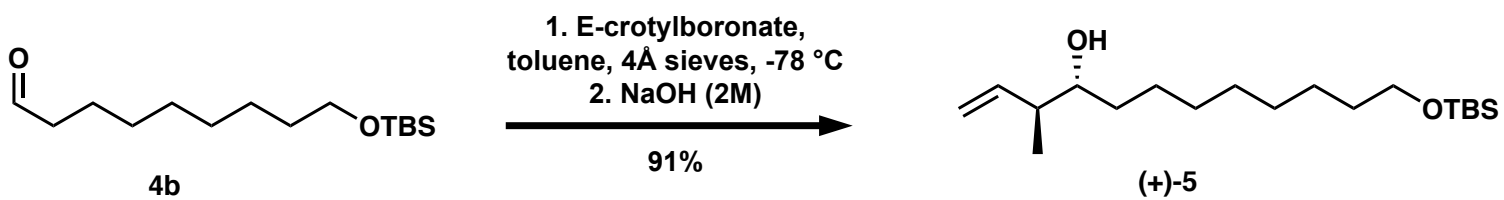

$(+)-5$

(3S,4R)-12-((tert-butyldimethylsilyl)oxy)-3-methyldodec-1-en-4-ol (+)-5) was synthesized according to Representative Procedure B: $3 a(200 \mathrm{mg}, 0.73 \mathrm{mmol})$, E-crotylboronate $(4.3 \mathrm{~mL}, 2.2$ $\mathrm{mmol})$, toluene $(7 \mathrm{~mL}), 4 \AA$ molecular sieves $(49 \mathrm{mg})$, and $2 \mathrm{M} \mathrm{NaOH}(2.8 \mathrm{~mL})$ yielded $220 \mathrm{mg}$ of $(+)-4 a)\left(91 \%\right.$ yield). Purified by column chromatography (0 to $15 \%$ EtOAc:Hexanes). $\mathbf{R}_{\boldsymbol{f}}=0.22$ (30\% EtOAc:Hexanes). ${ }^{1} \mathrm{H}$ NMR $\left(500 \mathrm{MHz} \mathrm{CDCl}_{3}\right) \delta 5.75$ (ddd, $\left.J=16.9,10.7,8.2 \mathrm{~Hz}, 1 \mathrm{H}\right), 5.13$ (tt, $J=1.9,1.1 \mathrm{~Hz}, 1 \mathrm{H}$ ), 5.10 (ddd, $J=9.9,1.9,0.9 \mathrm{~Hz}, 1 \mathrm{H}$ ), 3.59 (t, $J=6.6 \mathrm{~Hz}, 2 \mathrm{H}$ ), 3.38 (ddd, $J$ $=8.0,5.9,3.3 \mathrm{~Hz}, 1 \mathrm{H}), 2.24-2.16(\mathrm{~m}, 1 \mathrm{H}), 1.53-1.48(\mathrm{~m}, 4 \mathrm{H}), 1.41-1.33(\mathrm{~m}, 2 \mathrm{H}), 1.29(\mathrm{~s}$, $10 \mathrm{H}), 1.03(\mathrm{~d}, J=6.9 \mathrm{~Hz}, 3 \mathrm{H}), 0.89(\mathrm{~s}, 9 \mathrm{H}), 0.04(\mathrm{~s}, 6 \mathrm{H}) .{ }^{13} \mathrm{C}$ NMR $\left(126 \mathrm{MHz}, \mathrm{CDCl}_{3}\right) \delta 140.54$, 116.40, 74.87, 63.49, 44.29, 34.43, 33.05, 29.84, 29.78, 29.57, 26.16, 25.96, 25.89, 18.55, 16.48, -5.08. HRMS (ES $)$ : Found $329.28742(1.17 \mathrm{ppm}), \mathrm{C}_{19} \mathrm{H}_{41} \mathrm{O}_{2} \mathrm{Si}\left(\mathrm{M}+\mathrm{H}^{+}\right)$requires 329.28311. IR $3371.33(\mathrm{OH}), 2927.91,2855.36(\mathrm{C}-\mathrm{H}), 1638.69(\mathrm{C}=\mathrm{C}), 1462.52,1387.75,1360.65,1254.35$, $1099.04 \mathrm{~cm}^{-1} .[\alpha]^{25}+0.28\left(c=1.0\right.$ in $\left.\mathrm{CHCl}_{3}\right)$.

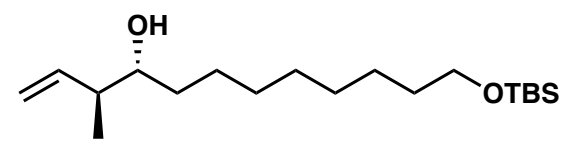

$(+)-5$

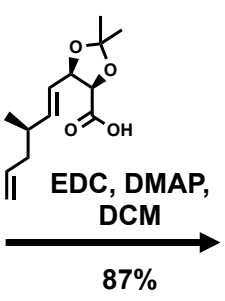

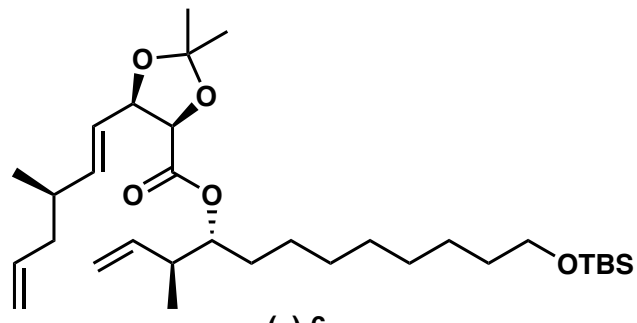

$(-)-6$

(3S,4R)-12-((tert-butyldimethylsilyl)oxy)-3-methyldodec-1-en-4-yl $\quad(4 R, 5 R)-2,2-d i m e t h y l-5-$ ((S)-3-methylhex-5-en-1-yl)-1,3-dioxolane-4-carboxylate ((-)-6) was synthesized according to Representative Procedure C: (+)-4a) (155 mg, 0.4716 mmol), acid precursor ${ }^{2}$ (170 mg, 0.7074 
$\mathrm{mmol})$, EDC (180 mg, .9432 mmol), 4-(dimethylamino)pyridine (5.8 mg, $0.0472 \mathrm{mmol})$ in DCM $(12 \mathrm{~mL})$ yielded $260 \mathrm{mg}$ of $((-)-5 \mathrm{a})$ (87\% yield). Purified by column chromatography (0 to $5 \%$ EtOAc:Hexanes). $\mathbf{R}_{\boldsymbol{f}}=0.50$ (10\% EtOAc:Hexanes). ${ }^{1} \mathrm{H}$ NMR $\left(500 \mathrm{MHz}, \mathrm{CDCl}_{3}\right) \delta 5.82(\mathrm{dd}, \mathrm{J}=$ 15.4, 7.1 Hz, 1H), $5.79-5.68(\mathrm{~m}, 2 \mathrm{H}), 5.37$ (ddd, $J=15.4,8.2,1.2 \mathrm{~Hz}, 1 \mathrm{H}), 5.07-4.97(\mathrm{~m}, 4 \mathrm{H})$, $4.89(\mathrm{dt}, J=8.5,4.2 \mathrm{~Hz}, 1 \mathrm{H}), 4.77-4.72(\mathrm{~m}, 1 \mathrm{H}), 4.59(\mathrm{~d}, J=6.9 \mathrm{~Hz}, 1 \mathrm{H}), 3.58(\mathrm{t}, J=6.6 \mathrm{~Hz}$, $2 \mathrm{H}), 2.43(\mathrm{dq}, J=10.7,6.8 \mathrm{~Hz}, 1 \mathrm{H}), 2.22(\mathrm{p}, J=6.9,6.4 \mathrm{~Hz}, 1 \mathrm{H}), 2.17-2.09(\mathrm{~m}, 1 \mathrm{H}), 2.02-1.94$ $(\mathrm{m}, 1 \mathrm{H}), 1.62(\mathrm{~s}, 3 \mathrm{H}), 1.52-1.45(\mathrm{~m}, 4 \mathrm{H}), 1.40(\mathrm{~s}, 3 \mathrm{H}), 1.26(\mathrm{~s}, 12 \mathrm{H}), 0.99(\mathrm{~d}, J=6.9 \mathrm{~Hz}, 3 \mathrm{H})$, $0.97(\mathrm{~d}, J=6.7 \mathrm{~Hz}, 3 \mathrm{H}), 0.89(\mathrm{~s}, 9 \mathrm{H}), 0.04(\mathrm{~s}, 6 \mathrm{H}) .{ }^{13} \mathrm{C}$ NMR $\left(126 \mathrm{MHz}, \mathrm{CDCl}_{3}\right) \delta 169.67,142.76$, 139.23, 136.65, 122.44, 116.35, 115.83, 110.84, 79.29, 78.40, 78.17, 63.45, 40.94, 40.91, 36.19, 33.02, 30.79, 29.60, 29.53, 27.18, 26.13, 25.92, 25.89, 25.71, 19.25, 18.52, 15.65, -5.11. HRMS $\left(\right.$ ES $\left.^{+}\right)$: Found $551.41263(0.31 \mathrm{ppm}), \mathrm{C}_{32} \mathrm{H}_{58} \mathrm{O}_{5} \mathrm{Si}\left(\mathrm{M}+\mathrm{H}^{+}\right)$requires 551.41263. IR 2929.02, $2856.35(\mathrm{C}-\mathrm{H}), 1754.22,1736.84,1729.15(\mathrm{C}=\mathrm{O}), 1461.73,1452.73,1380.07,1093.66 \mathrm{~cm}^{-1}$. $[\alpha]^{25}-17.5\left(c=1.0\right.$ in $\left.\mathrm{CHCl}_{3}\right)$.

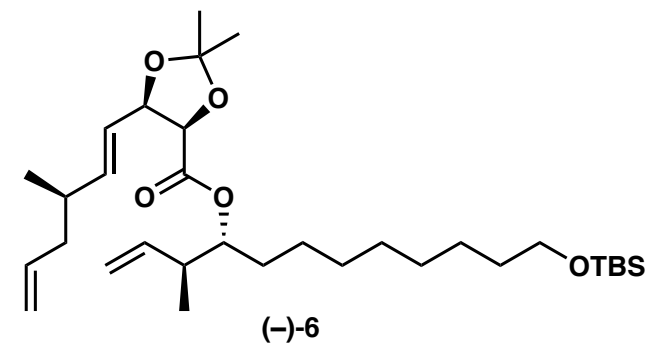

$(-)-6$

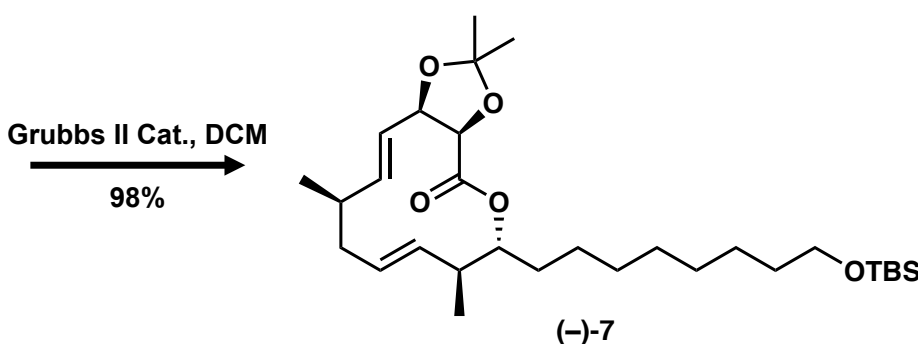

$(-)-7$

(3aR,6R,7S,8E,11R,12E,13aR)-6-(8-((tert-butyldimethylsilyl)oxy)octyl)-2,2,7,11-tetramethyl3a,6,7,10,11,13a-hexahydro-4H-[1,3]dioxolo[4,5-c][1]oxacyclododecin-4-one $((-)-7)$ was synthesized according to Representative Procedure D: ((-)-5a) (174 mg, $0.316 \mathrm{mmol})$, Grubbs II Generation Catalyst $(14.9 \mathrm{mg}, 0.176 \mathrm{mmol})$ in DCM $(70 \mathrm{~mL})$ yielded $161 \mathrm{mg}$ of $((-)-6 a)(98 \%$ yield). Purified by column chromatography (0 to $10 \%$ EtOAc:Hexanes). $\mathbf{R}_{\boldsymbol{f}}=0.54(10 \%$ EtOAc:Hexanes). ${ }^{1} \mathbf{H}$ NMR $\left(400 \mathrm{MHz}, \mathrm{CDCl}_{3}\right) \delta 5.73$ (ddd, $\left.J=15.7,7.4,1.1 \mathrm{~Hz}, 1 \mathrm{H}\right), 5.25$ (ddd, $J$ $=15.7,6.9,1.1 \mathrm{~Hz}, 1 \mathrm{H}), 5.12-5.07(\mathrm{~m}, 2 \mathrm{H}), 4.82-4.70(\mathrm{~m}, 2 \mathrm{H}), 4.52(\mathrm{~d}, J=6.7 \mathrm{~Hz}, 1 \mathrm{H}), 3.58$ $(\mathrm{t}, J=6.6 \mathrm{~Hz}, 2 \mathrm{H}), 2.25-2.14(\mathrm{~m}, 3 \mathrm{H}), 1.98-1.88(\mathrm{~m}, 1 \mathrm{H}), 1.70(\mathrm{~s}, 3 \mathrm{H}), 1.67-1.60(\mathrm{~m}, 1 \mathrm{H})$, $1.48(\mathrm{q}, J=6.9 \mathrm{~Hz}, 3 \mathrm{H}), 1.41(\mathrm{~s}, 3 \mathrm{H}), 1.25(\mathrm{~s}, 12 \mathrm{H}), 1.05(\mathrm{~d}, J=6.7 \mathrm{~Hz}, 3 \mathrm{H}), 0.96$ (d, J = $6.8 \mathrm{~Hz}$, $3 \mathrm{H}), 0.89(\mathrm{~s}, 9 \mathrm{H}), 0.04(\mathrm{~s}, 6 \mathrm{H}) .{ }^{13} \mathrm{C}$ NMR $\left(100 \mathrm{MHz}, \mathrm{CDCl}_{3}\right) \delta 170.38,138.68,135.16,129.93$, 123.54, 111.05, 78.74, 78.57, 78.45, 63.43, 42.43, 38.85, 36.09, 32.98, 32.52, 29.70, 29.54, 29.50, 26.93, 26.12, 26.00, 25.88, 24.96, 21.28, 18.51, 18.21, -5.11. HRMS (ES ${ }^{+}$: Found 545.36404 (1.30 ppm), $\mathrm{C}_{30} \mathrm{H}_{54} \mathrm{O}_{5} \mathrm{Si}\left(\mathrm{M}+\mathrm{Na}^{+}\right)$requires 545.36327. IR 2928.56, $2856.00(\mathrm{C}-\mathrm{H})$, $1751.20(\mathrm{C}=\mathrm{O}), 1461.80,1379.01,1253.12,1223.29,1186.18,1088.12 \mathrm{~cm}^{-1} \cdot[\alpha]^{25} \mathrm{D}-13.4(c=1.0$ in $\left.\mathrm{CHCl}_{3}\right)$.

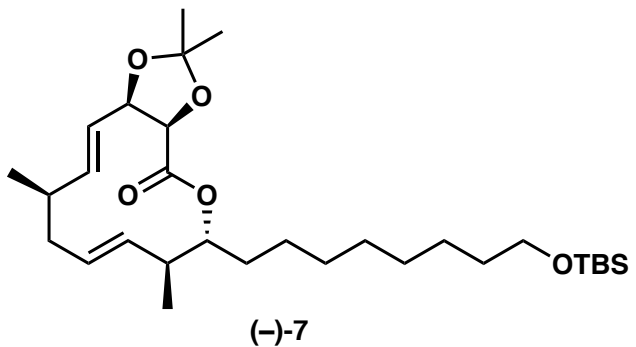

$(-)-7$

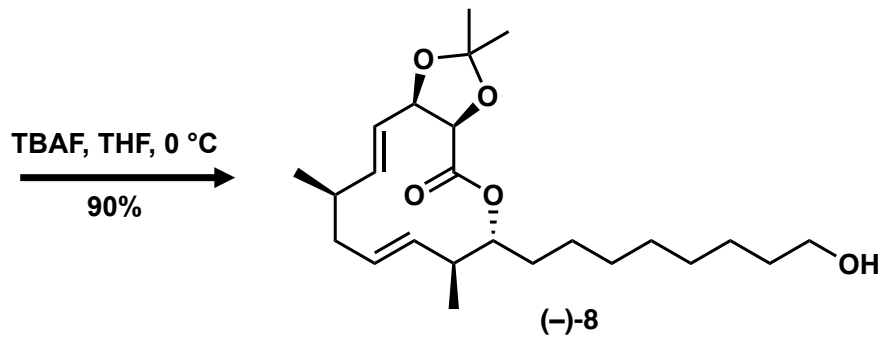

$(-)-8$ 
$(3 a R, 6 R, 7 S, 8 E, 11 R, 12 E, 13 a R)-6-(8-h y d r o x y o c t y l)-2,2,7,11$-tetramethyl-3a,6,7,10,11,13ahexahydro-4H-[1,3]dioxolo[4,5-c][1]oxacyclododecin-4-one $((-)-8)$ was synthesized according to Representative Procedure E: ((-)-6a) $(50.0 \mathrm{mg}, 0.0960 \mathrm{mmol})$, tetrabutylammonium fluoride solution (1 M, $0.28 \mathrm{ml}, 0.2794 \mathrm{mmol})$ in THF $(1 \mathrm{ml})$ yielded $34.3 \mathrm{mg}(90 \%$ yield). Purified by column chromatography (30\% EtOAc:Hexanes). $\mathbf{R}_{\boldsymbol{f}}=0.39$ (30\% EtOAc:Hexanes). ${ }^{1} \mathbf{H}$ NMR $\left(400 \mathrm{MHz} \mathrm{CDCl}_{3}\right) \delta 5.74(\mathrm{dd}, J=15.7,7.1 \mathrm{~Hz}, 1 \mathrm{H}), 5.25(\mathrm{dd}, J=15.8,6.8 \mathrm{~Hz}, 1 \mathrm{H}), 5.09(\mathrm{dd}, J=$ 6.3, 3.0 Hz, 2H), $4.83-4.70(\mathrm{~m}, 2 \mathrm{H}), 4.52(\mathrm{~d}, J=6.6 \mathrm{~Hz}, 1 \mathrm{H}), 3.63(\mathrm{t}, J=6.6 \mathrm{~Hz}, 2 \mathrm{H}), 2.19$ (ddd, $J=15.1,9.5,3.0 \mathrm{~Hz}, 3 \mathrm{H}), 1.94(\mathrm{tdd}, J=13.9,8.2,4.1 \mathrm{~Hz}, 1 \mathrm{H}), 1.70(\mathrm{~s}, 3 \mathrm{H}), 1.65-1.59(\mathrm{~m}, 1 \mathrm{H})$, $1.55(\mathrm{p}, J=6.7 \mathrm{~Hz}, 3 \mathrm{H}), 1.41(\mathrm{~s}, 3 \mathrm{H}), 1.32-1.22(\mathrm{~m}, 12 \mathrm{H}), 1.05(\mathrm{~d}, J=6.7 \mathrm{~Hz}, 3 \mathrm{H}), 0.96(\mathrm{~d}, J=$ $6.8 \mathrm{~Hz}, 3 \mathrm{H}) .{ }^{13} \mathrm{C}$ NMR $\left(100 \mathrm{MHz}, \mathrm{CDCl}_{3}\right) \delta 170.37,138.68,135.11,129.92,123.48,111.05,78.71$, 78.53, 78.40, 63.05, 42.43, 38.82, 36.05, 32.82, 32.48, 29.53, 29.40, 29.35, 26.89, 25.96, 25.73, 24.90, 21.24, 18.18. HRMS (ES $\left.{ }^{+}\right)$: Found $431.27696(0.38 \mathrm{ppm}), \mathrm{C}_{24} \mathrm{H}_{40} \mathrm{O}_{5}\left(\mathrm{M}+\mathrm{Na}^{+}\right)$requires 431.27680. IR 3430.00 (OH), 2928.10, $2855.58(\mathrm{C}-\mathrm{H})), 1753.69,1745.55,1726.59(\mathrm{C}=\mathrm{O})$, 1188.55, $1086.13 \mathrm{~cm}^{-1}$. [a] ${ }^{25} \mathrm{D}-9.3\left(c=1.0\right.$ in $\left.\mathrm{CHCl}_{3}\right)$.
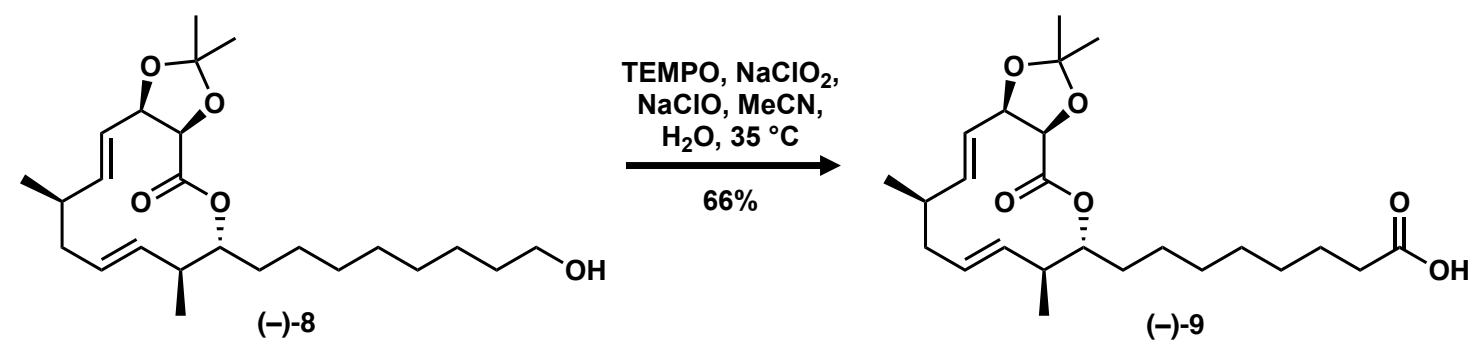

8-((3aR,6R,7S,8E,11R,12E,13aR)-2,2,7,11-tetramethyl-4-oxo-3a,6,7,10,11,13a-hexahydro4H-[1,3]dioxolo[4,5-c][1]oxacyclododecin-6-yl)octanoic acid ((-)-9) was synthesized according to Representative Procedure F: ((-)-7a) (34.5 mg, $0.0844 \mathrm{mmol})$, TEMPO (1.0 mg, $0.0059 \mathrm{mmol})$, sodium chlorite $(19 \mathrm{mg}, 0.1688 \mathrm{mmol})$ in $0.25 \mathrm{~mL} \mathrm{H}_{2} \mathrm{O}$, bleach $(8.25 \%$ sodium hypochlorite) $(0.01 \mathrm{ml})$ in $0.25 \mathrm{ml} \mathrm{H} 2 \mathrm{O}$, sodium phosphate buffer $(0.67 \mathrm{M}, \mathrm{pH} 6.7,0.31 \mathrm{ml})$ in $\mathrm{CH}_{3} \mathrm{CN}(0.4 \mathrm{ml})$ yielded $23.4 \mathrm{mg}$ of $((-)-8 \mathrm{a})(66 \%$ yield). Purified by column chromatography ( 0 to $50 \%$ EtOAc [with 0.01\% acetic acid]:Hexanes). $\mathbf{R}_{\boldsymbol{f}}=0.12$ (50\% EtOAc:Hexanes). ${ }^{1} \mathbf{H}$ NMR (500 $\left.\mathrm{MHz} \mathrm{CDCl}_{3}\right) 5.73(\mathrm{dd}, J=15.7,7.2 \mathrm{~Hz}, 1 \mathrm{H}), 5.24(\mathrm{dd}, J=15.6,6.9 \mathrm{~Hz}, 1 \mathrm{H}), 5.11-5.07(\mathrm{~m}, 2 \mathrm{H}), 4.80$ $-4.72(\mathrm{~m}, 2 \mathrm{H}), 4.53(\mathrm{~d}, J=6.7 \mathrm{~Hz}, 1 \mathrm{H}), 2.33(\mathrm{t}, J=7.4 \mathrm{~Hz}, 2 \mathrm{H}), 2.22-2.15(\mathrm{~m}, 3 \mathrm{H}), 1.96-1.89(\mathrm{~m}$, $1 \mathrm{H}), 1.69(\mathrm{~s}, 3 \mathrm{H}), 1.61(\mathrm{td}, J=13.3,5.9 \mathrm{~Hz}, 4 \mathrm{H}), 1.41(\mathrm{~s}, 3 \mathrm{H}), 1.29-1.24(\mathrm{~m}, 8 \mathrm{H}), 1.05(\mathrm{~d}, J=6.7 \mathrm{~Hz}$, $3 \mathrm{H}), 0.96(\mathrm{~d}, \mathrm{~J}=6.7 \mathrm{~Hz}, 3 \mathrm{H}) .{ }^{13} \mathrm{C}$ NMR $\left(126 \mathrm{MHz} \mathrm{CDCl}_{3}\right) \delta 179.37,170.37,138.75,135.14,129.97$, 123.53, 111.14, 78.76, 78.56, 78.43, 42.43, 38.88, 36.11, 34.07, 32.48, 29.37, 29.03, 28.94, 26.93, 26.00, 24.84, 24.71, 21.27, 18.20. HRMS (APCl): Found 421.26005 (0.49 ppm), $\mathrm{C}_{24} \mathrm{H}_{38} \mathrm{O}_{6}$ $\left(\mathrm{M}-\mathrm{H}^{+}\right)$requires 421.25956. IR 2927.92, $2855.92(\mathrm{C}-\mathrm{H}), 1747.04,1708.65(\mathrm{C}=\mathrm{O}), 1457.04$, $1379.41,1188.81,1086.56 \mathrm{~cm}^{-1} .[\alpha]^{25}-10.2\left(c=1.0\right.$ in $\left.\mathrm{CHCl}_{3}\right)$. 

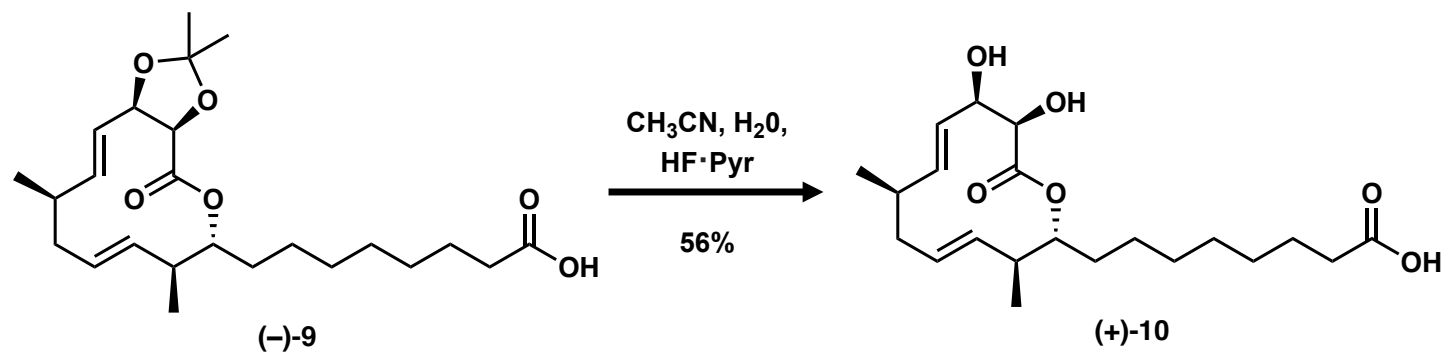

$(+)-10$

8-((2R,3S,4E,7R,8E,10R,11R)-10,11-dihydroxy-3,7-dimethyl-12-oxooxacyclododeca-4,8dien-2-yl)octanoic acid (+)-10) was synthesized according to Representative Procedure G: (()-8a) (10 mg, $0.0237 \mathrm{mmol})$, HF.pyridine (0.34 ml), $\mathrm{H}_{2} \mathrm{O}(0.01 \mathrm{~mL})$ in $\mathrm{CH}_{3} \mathrm{CN}(5 \mathrm{~mL})$ yielded $5 \mathrm{mg}$ of (+)-9a) (56\% yield). Purified by column chromatography (0 to $50 \%$ EtOAc [with $0.01 \%$ acetic acid]:Hexanes). $\mathbf{R}_{\boldsymbol{f}}=0.38(10 \% \mathrm{MeOH}: \mathrm{DCM}) .{ }^{1} \mathbf{H}$ NMR $\left(400 \mathrm{MHz}, \mathrm{CDCl}_{3}\right) \delta 5.35-5.24(\mathrm{~m}, 2 \mathrm{H})$, 5.14 (ddd, $J=14.8,10.9,3.8 \mathrm{~Hz}, 1 \mathrm{H}), 4.90$ (dd, $J=15.0,9.5 \mathrm{~Hz}, 1 \mathrm{H}$ ), 4.73 (ddd, $J=10.7,7.7$, $2.9 \mathrm{~Hz}, 1 \mathrm{H}), 4.42(\mathrm{~s}, 1 \mathrm{H}), 4.13(\mathrm{~d}, J=3.2 \mathrm{~Hz}, 1 \mathrm{H}), 2.34(\mathrm{t}, J=7.3 \mathrm{~Hz}, 2 \mathrm{H}), 2.23(\mathrm{td}, J=10.1,6.8$ $\mathrm{Hz}, 1 \mathrm{H}), 2.19-2.12(\mathrm{~m}, 2 \mathrm{H}), 1.68-1.60(\mathrm{~m}, 4 \mathrm{H}), 1.31(\mathrm{~s}, 5 \mathrm{H}), 1.25(\mathrm{~s}, 4 \mathrm{H}), 1.04(\mathrm{~d}, \mathrm{~J}=6.5 \mathrm{~Hz}$, $3 \mathrm{H}), 0.95(\mathrm{~d}, J=6.8 \mathrm{~Hz}, 3 \mathrm{H}) .{ }^{13} \mathrm{C}$ NMR $\left(151 \mathrm{MHz}, \mathrm{CDCl}_{3}\right) \delta 177.67,172.80,135.67,134.74$, 130.27, 126.41, 78.57, 73.55, 73.41, 41.99, 40.93, 38.10, 33.78, 31.83, 28.92, 28.67, 28.46, 24.59, 24.01, 21.29, 18.02. HRMS (APCl): Found $381.22826(0.33 \mathrm{ppm}), \mathrm{C}_{21} \mathrm{H}_{34} \mathrm{O}_{6}\left(\mathrm{M}^{-} \mathrm{H}^{+}\right)$ requires 381.22826. IR $3422.41(\mathrm{O}-\mathrm{H}), 2924.83,2852.86(\mathrm{C}-\mathrm{H}), 1717.21(\mathrm{C}=\mathrm{O}), 1456.95$, 1196.87, $1077.90 \mathrm{~cm}^{-1} .[\alpha]^{25}+16.9\left(\mathrm{c}=0.33\right.$ in $\left.\mathrm{CHCl}_{3}\right)$.

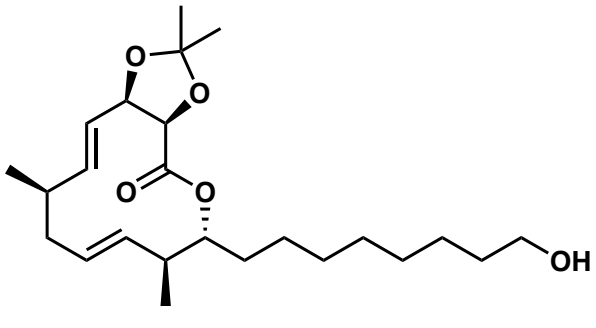

$(-)-8$
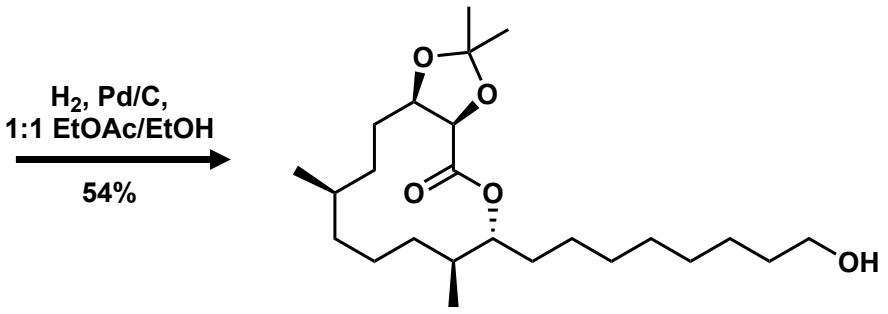

$(+)-11$

(3aR,6R,7S,11R,13aR)-6-(8-hydroxyoctyl)-2,2,7,11-tetramethyldecahydro-4H-

[1,3]dioxolo[4,5-c][1]oxacyclododecin-4-one (+)-11) was synthesized according to Representative Procedure H: ((-)-7a) (32 mg, $0.0908 \mathrm{mmol}), \mathrm{Pd} / \mathrm{C} \mathrm{10 \%} \mathrm{(14} \mathrm{mg,} 15 \mathrm{~mol} \%$ catalyst load) in 1:1 EtOAc:EtOH (4.5 mL) yielded $17.2 \mathrm{mg}$ of (+)-10a) (54\% yield). Purified by column chromatography (0 to 20\% EtOAc:Hexanes). $\mathbf{R}_{\boldsymbol{f}}=0.40$ (20\% EtOAc:Hexanes). ${ }^{1} \mathbf{H}$ NMR (500 $\left.\mathrm{MHz} \mathrm{CDCl}_{3}\right) \delta 4.78$ (ddd, $J=10.0,6.3,3.4 \mathrm{~Hz}, 1 \mathrm{H}$ ), 4.56 (d, $J=6.1 \mathrm{~Hz}, 1 \mathrm{H}$ ), 4.36 (ddd, $J=9.7$, 6.1, 3.2 Hz, 1H), 3.63 (t, $J=6.7 \mathrm{~Hz}, 2 \mathrm{H}$ ), 1.83 (dp, $J=10.7,3.7 \mathrm{~Hz}, 1 \mathrm{H}$ ), 1.76 (ddd, $J=10.4,5.1$, $2.4 \mathrm{~Hz}, 1 \mathrm{H}), 1.70(\mathrm{tt}, J=10.1,4.3 \mathrm{~Hz}, 3 \mathrm{H}), 1.63(\mathrm{~s}, 3 \mathrm{H}), 1.60-1.52(\mathrm{~m}, 4 \mathrm{H}), 1.48$ (ddt, $J=6.2$, 3.7, $2.1 \mathrm{~Hz}, 3 \mathrm{H}), 1.38(\mathrm{~s}, 3 \mathrm{H}), 1.31-1.25(\mathrm{~m}, 11 \mathrm{H}), 1.19-1.14(\mathrm{~m}, 2 \mathrm{H}), 1.03$ (ddd, J = 11.0, 9.0, $4.8 \mathrm{~Hz}, 1 \mathrm{H}), 0.89(\mathrm{dd}, J=8.6,6.9 \mathrm{~Hz}, 6 \mathrm{H}) .{ }^{13} \mathrm{C}$ NMR $\left(151 \mathrm{MHz}, \mathrm{CDCl}_{3}\right) \delta 170.09,110.01,79.15$, 78.18, 63.17, 36.06, 33.65, 32.89, 32.42, 31.70, 29.85, 29.72, 29.51, 29.41, 28.00, 27.36, 26.03, 25.78, 25.13, 25.11, 24.12, 21.96, 20.88, 16.96. HRMS (ES $\left.{ }^{+}\right)$: Found 413.32615 (0.68 ppm), $\mathrm{C}_{24} \mathrm{H}_{44} \mathrm{O}_{5}\left(\mathrm{M}-\mathrm{H}^{+}\right)$requires 413.32615. IR $3369.45(\mathrm{OH}), 2928.27,2856.35(\mathrm{C}-\mathrm{H}), 1746.00(\mathrm{C}=\mathrm{O})$, $1379.54,1184.56,1077.92 \mathrm{~cm}^{-1} .[\alpha]^{25} \mathrm{D}+38.9\left(c=1.0\right.$ in $\left.\mathrm{CHCl}_{3}\right)$. 


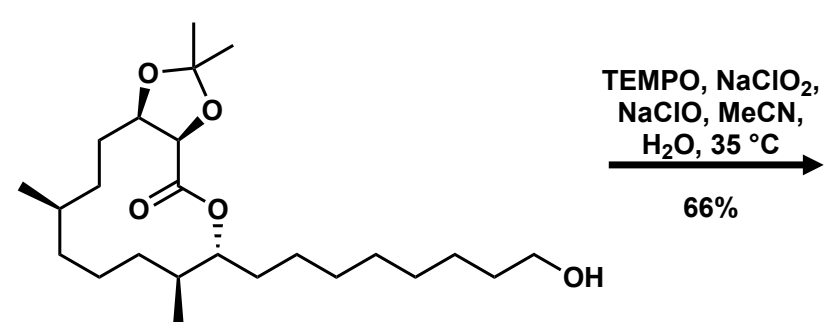

$(+)-11$

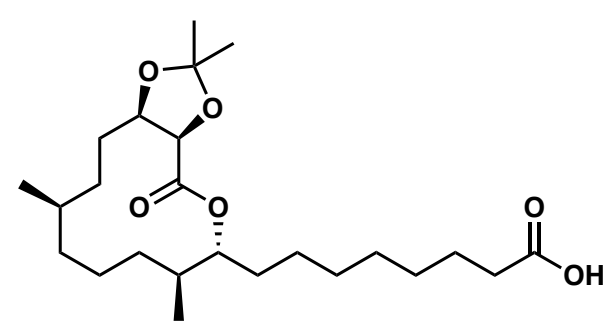

$(+)-2$

8-((3aR,6R,7S,11R,13aR)-2,2,7,11-tetramethyl-4-oxodecahydro-4H-[1,3]dioxolo[4,5c][1]oxacyclododecin-6-yl)octanoic acid ((+)-2) was synthesized according to Representative Procedure G: ((+)-10a (15 mg, $0.0363 \mathrm{mmol})$, TEMPO (4.5 mg, $0.0029 \mathrm{mmol})$, sodium chlorite $(8$ $\mathrm{mg}, 0.0842 \mathrm{mmol})$ in $0.5 \mathrm{~mL} \mathrm{H}_{2} \mathrm{O}$, bleach $\left(8.25 \%\right.$ sodium hypochlorite) $(0.01 \mathrm{ml})$ in $0.5 \mathrm{ml} \mathrm{H}_{2} \mathrm{O}$, sodium phosphate buffer $(0.67 \mathrm{M}, \mathrm{pH} 6.7,0.2 \mathrm{ml})$ in $\mathrm{CH}_{3} \mathrm{CN}(0.2 \mathrm{ml})$ yielded $10.6 \mathrm{mg}$ of $((+)-2)$ $(66 \%$ yield). Purified by column chromatography $(0$ to $50 \%$ EtOAc [with $0.01 \%$ acetic acid]:Hexanes). $\mathbf{R}_{\boldsymbol{f}}=0.67$ (50\% EtOAc:Hexanes with acetic acid). ${ }^{1} \mathbf{H} \mathbf{N M R}\left(600 \mathrm{MHz}, \mathrm{CDCl}_{3}\right) \delta$ 4.78 (ddd, $J=10.1,6.3,3.4 \mathrm{~Hz}, 1 \mathrm{H}$ ), $4.58(\mathrm{~d}, J=6.1 \mathrm{~Hz}, 1 \mathrm{H}), 4.37$ (ddd, $J=9.7,6.1,3.2 \mathrm{~Hz}, 1 \mathrm{H}$ ), $2.34(\mathrm{t}, J=7.4 \mathrm{~Hz}, 2 \mathrm{H}$ ), 1.84 (dddd, $J=14.0,10.5,6.9,3.3 \mathrm{~Hz}, 1 \mathrm{H}), 1.75(\mathrm{dd}, J=9.6,5.2 \mathrm{~Hz}$, $1 \mathrm{H}), 1.69$ (ddd, $J=14.4,9.3,3.9 \mathrm{~Hz}, 3 \mathrm{H}), 1.64(\mathrm{~s}, 3 \mathrm{H}), 1.47(\mathrm{ddt}, J=16.2,12.8,4.3 \mathrm{~Hz}, 3 \mathrm{H}$ ), 1.32 $-1.27(\mathrm{~m}, 8 \mathrm{H}), 1.25(\mathrm{~s}, 4 \mathrm{H}), 1.17(\mathrm{dp}, J=11.4,4.4 \mathrm{~Hz}, 3 \mathrm{H}), 1.04(\mathrm{ddd}, J=13.9,9.1,4.7 \mathrm{~Hz}, 1 \mathrm{H})$, 0.89 (dd, $J=9.7,6.8 \mathrm{~Hz}, 6 \mathrm{H}) .{ }^{13} \mathrm{C}$ NMR $\left(151 \mathrm{MHz} \mathrm{CDCl}_{3}\right) \delta 178.29,171.70,109.96,79.05,78.10$, 33.78, 33.50, 32.24, 31.44, 29.72, 29.26, 28.68, 27.83, 27.20, 27.13, 25.89, 24.93, 24.57, 23.80, 20.73, 20.00, 19.19, 19.12, 16.83. HRMS (ES+): Found $449.28747(0.24 \mathrm{ppm}), \mathrm{C}_{24} \mathrm{H}_{42} \mathrm{O}_{6}\left(\mathrm{M}^{\left.+\mathrm{Na}^{+}\right)}\right.$ requires 449.28736. IR 2929.50, $2857.77(\mathrm{C}-\mathrm{H}), 1746.37,1709.13(\mathrm{C}=\mathrm{O}), 1461.66,1379.86$, $1245.98,1184.66,1079.39 \mathrm{~cm}^{-1} \cdot[\alpha]^{25}+24.16\left(c=1.0\right.$ in $\left.\mathrm{CHCl}_{3}\right)$ 


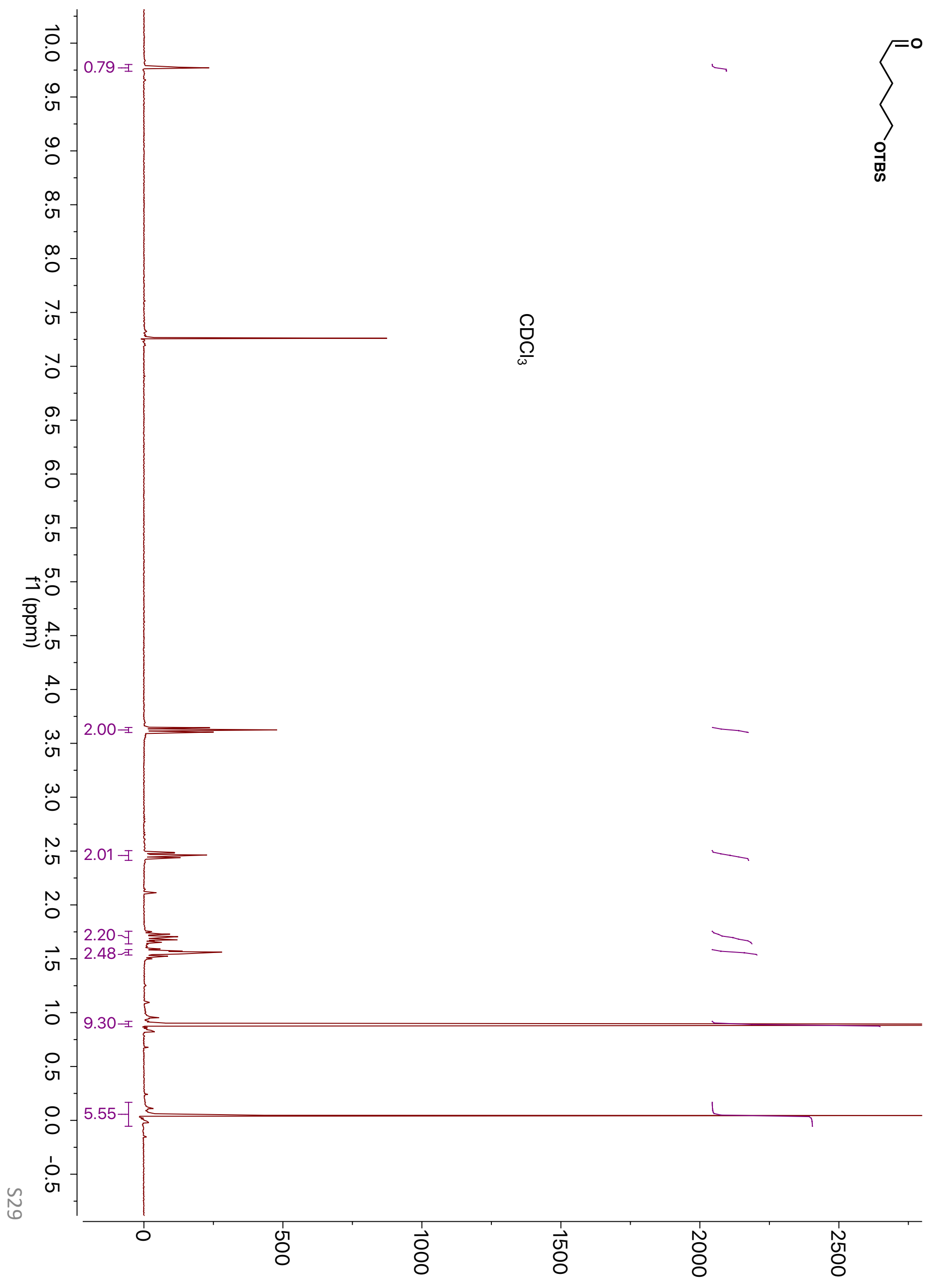




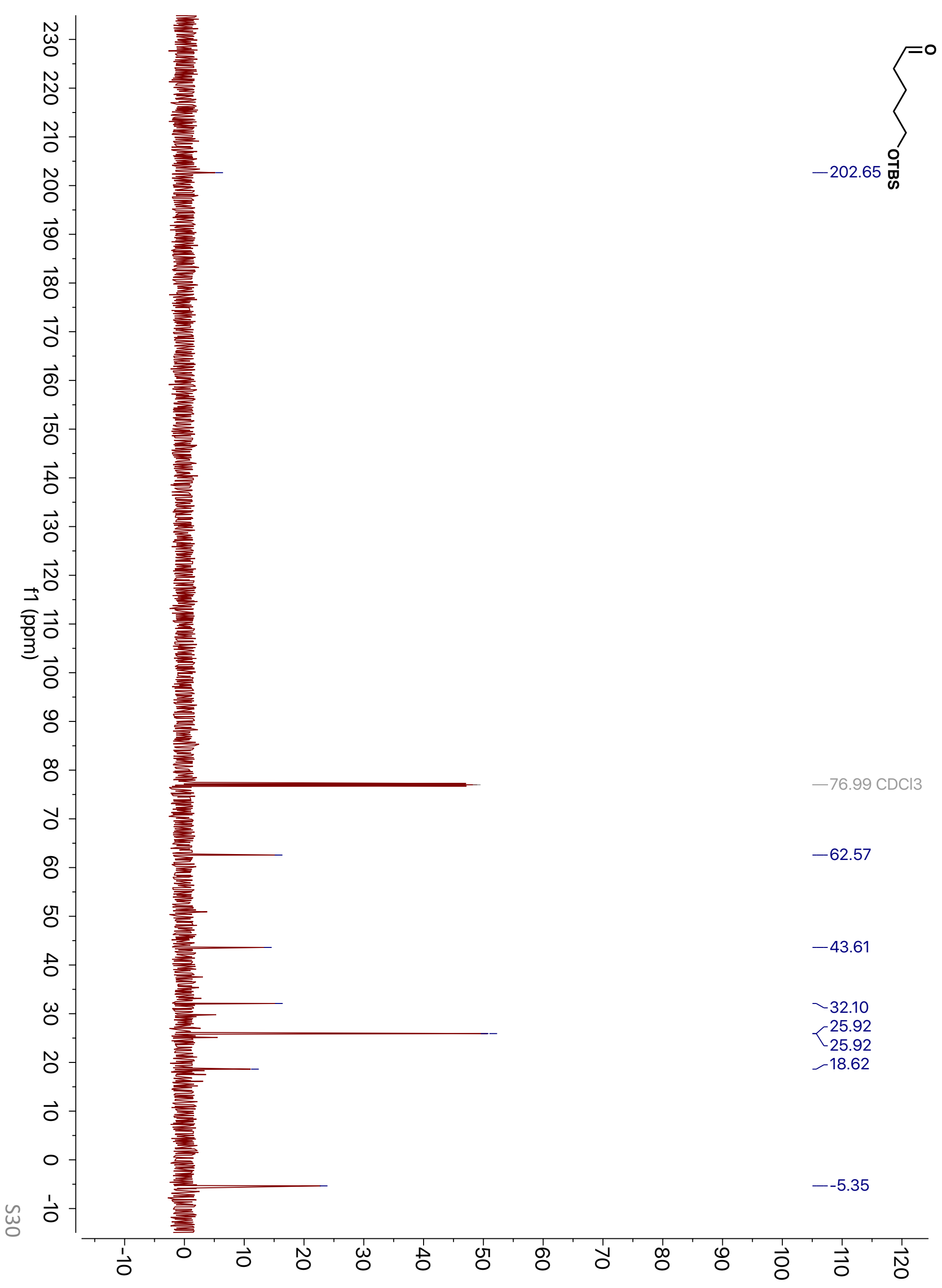




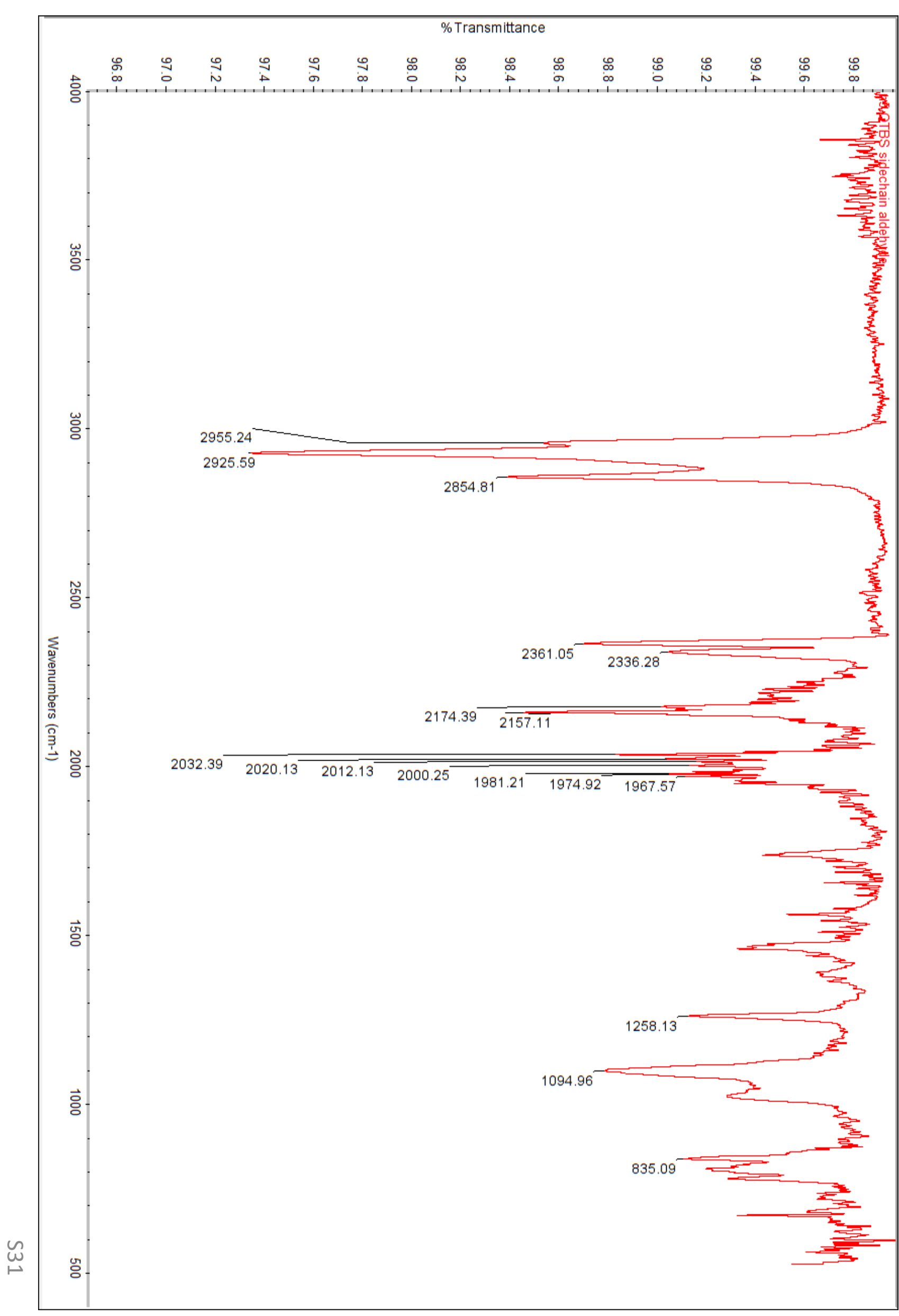




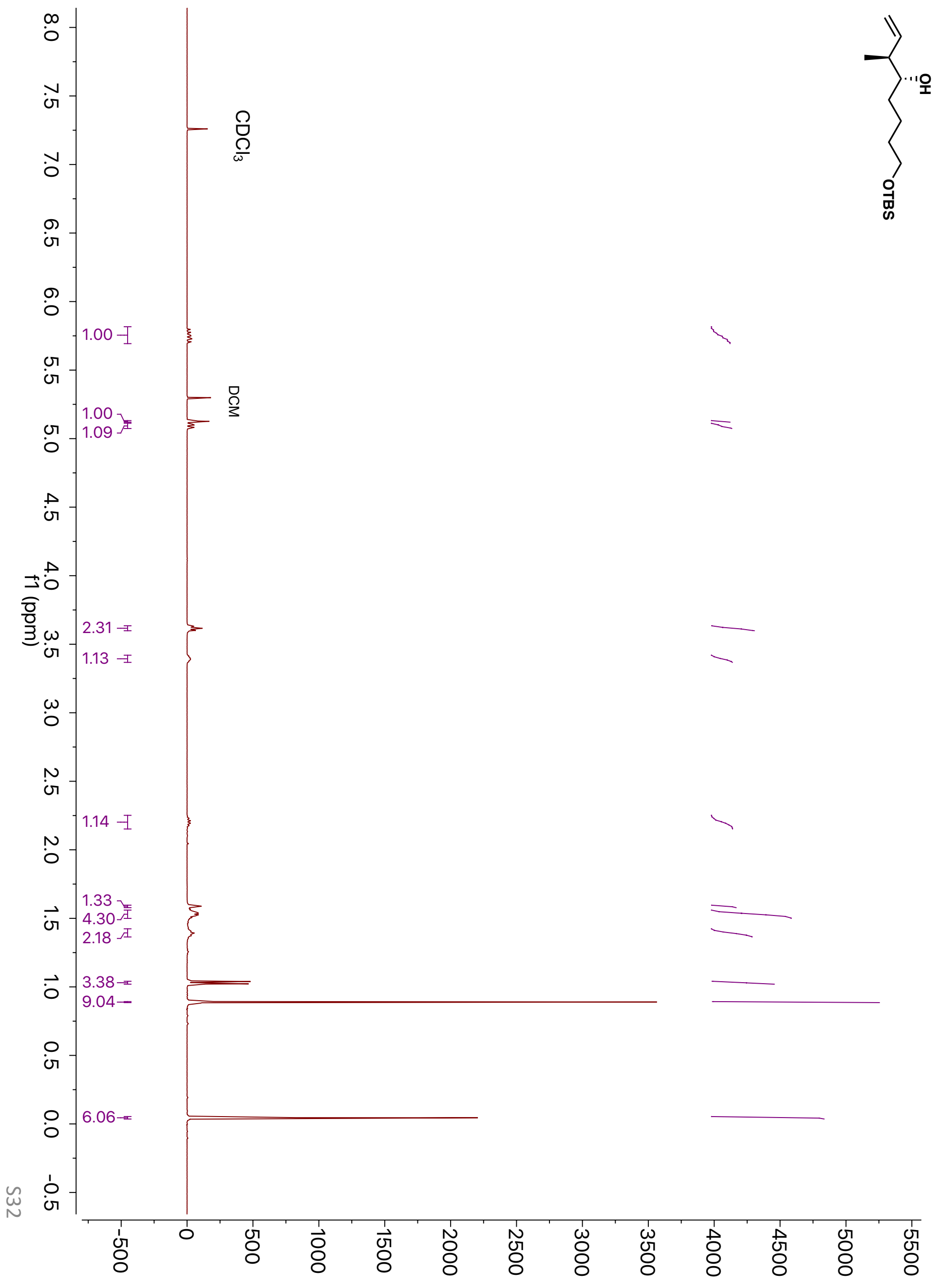




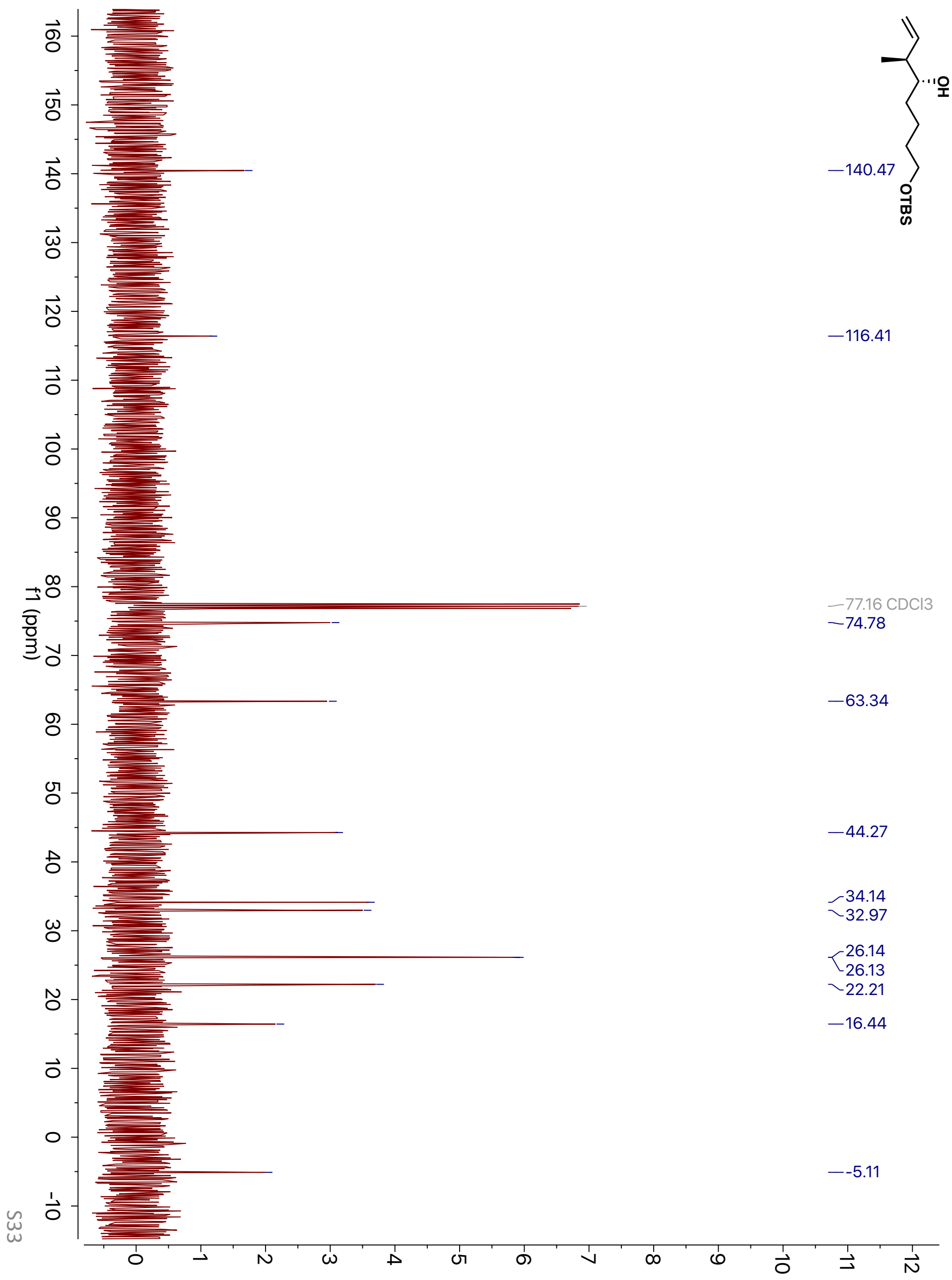




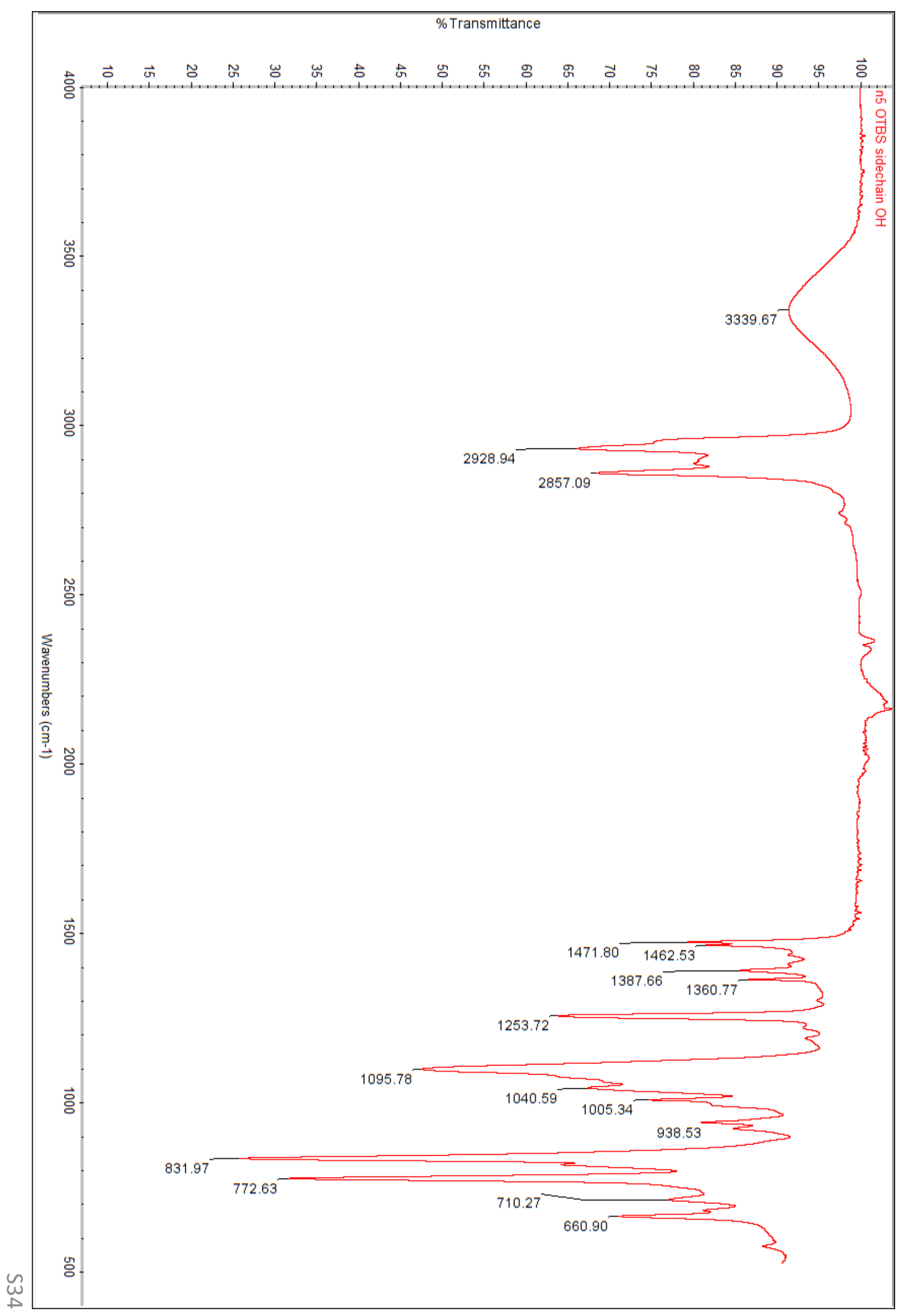




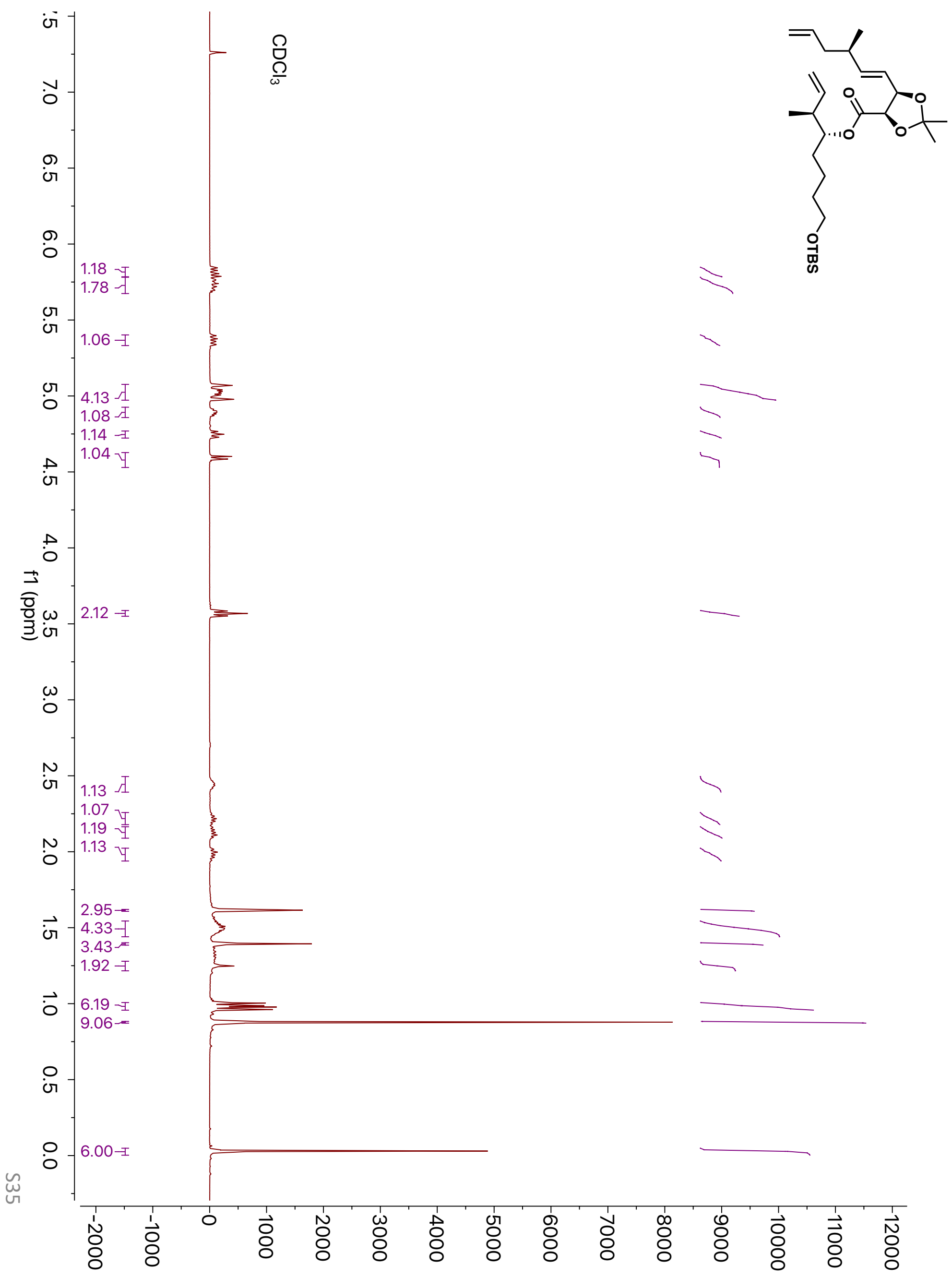




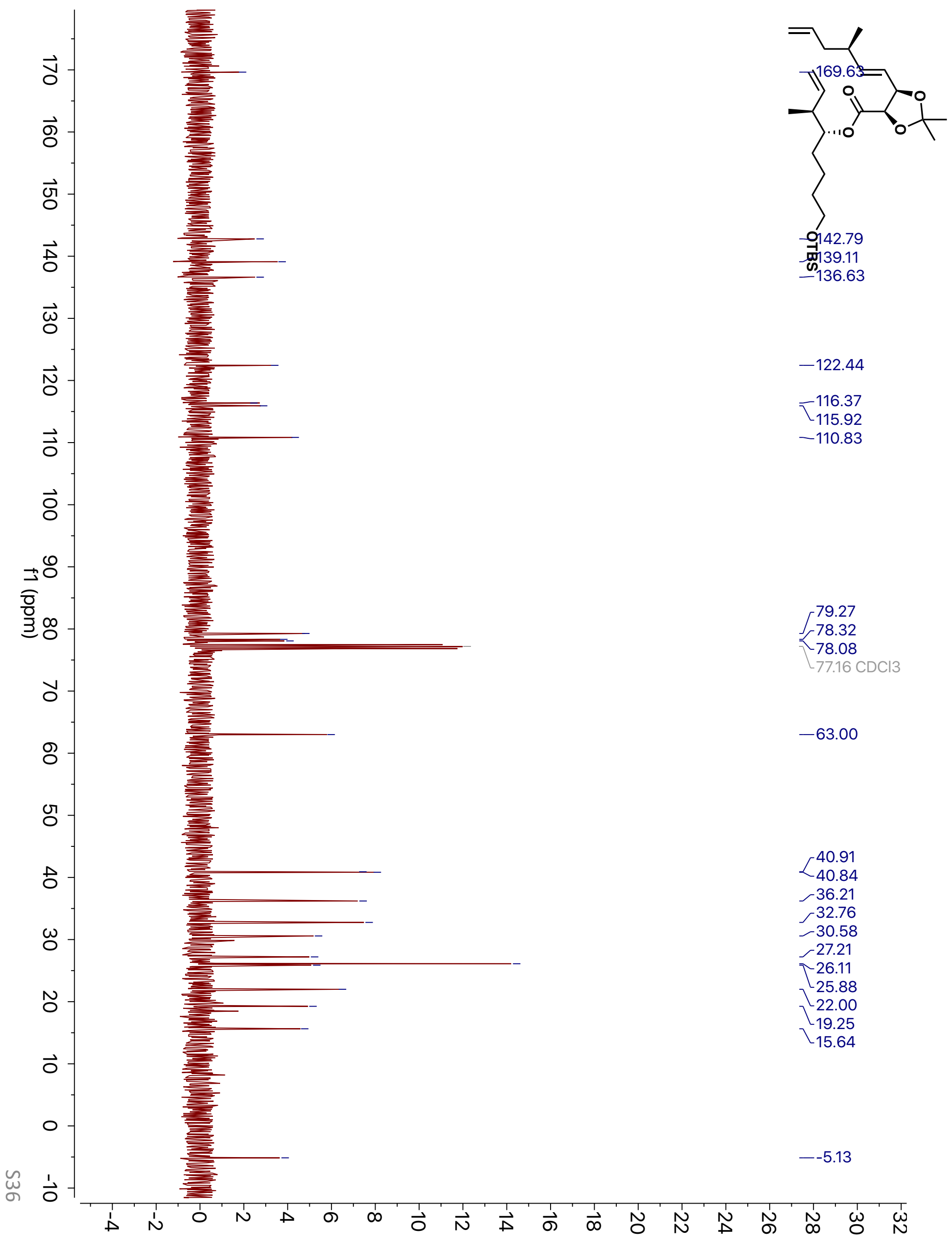


\% Transmittance

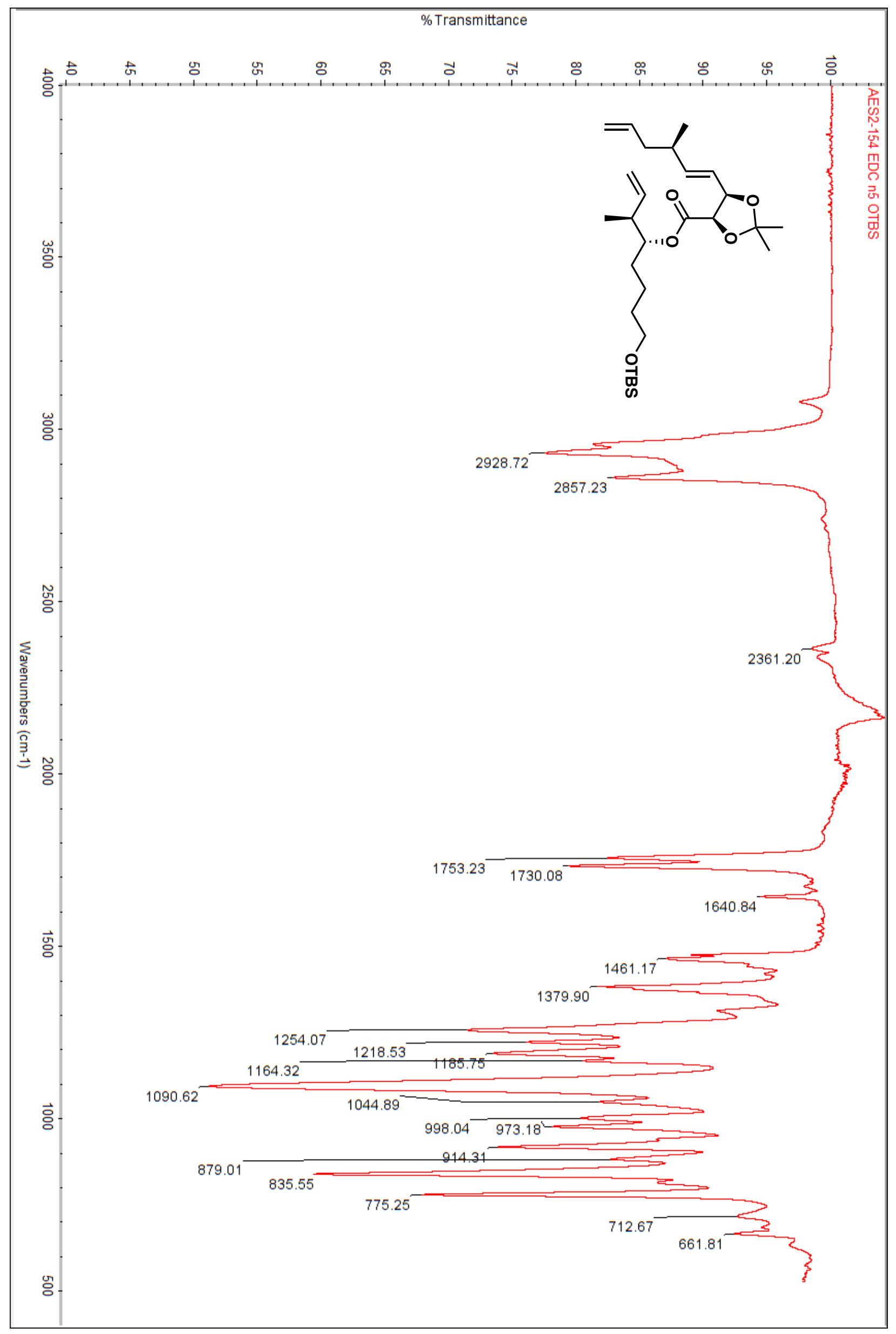




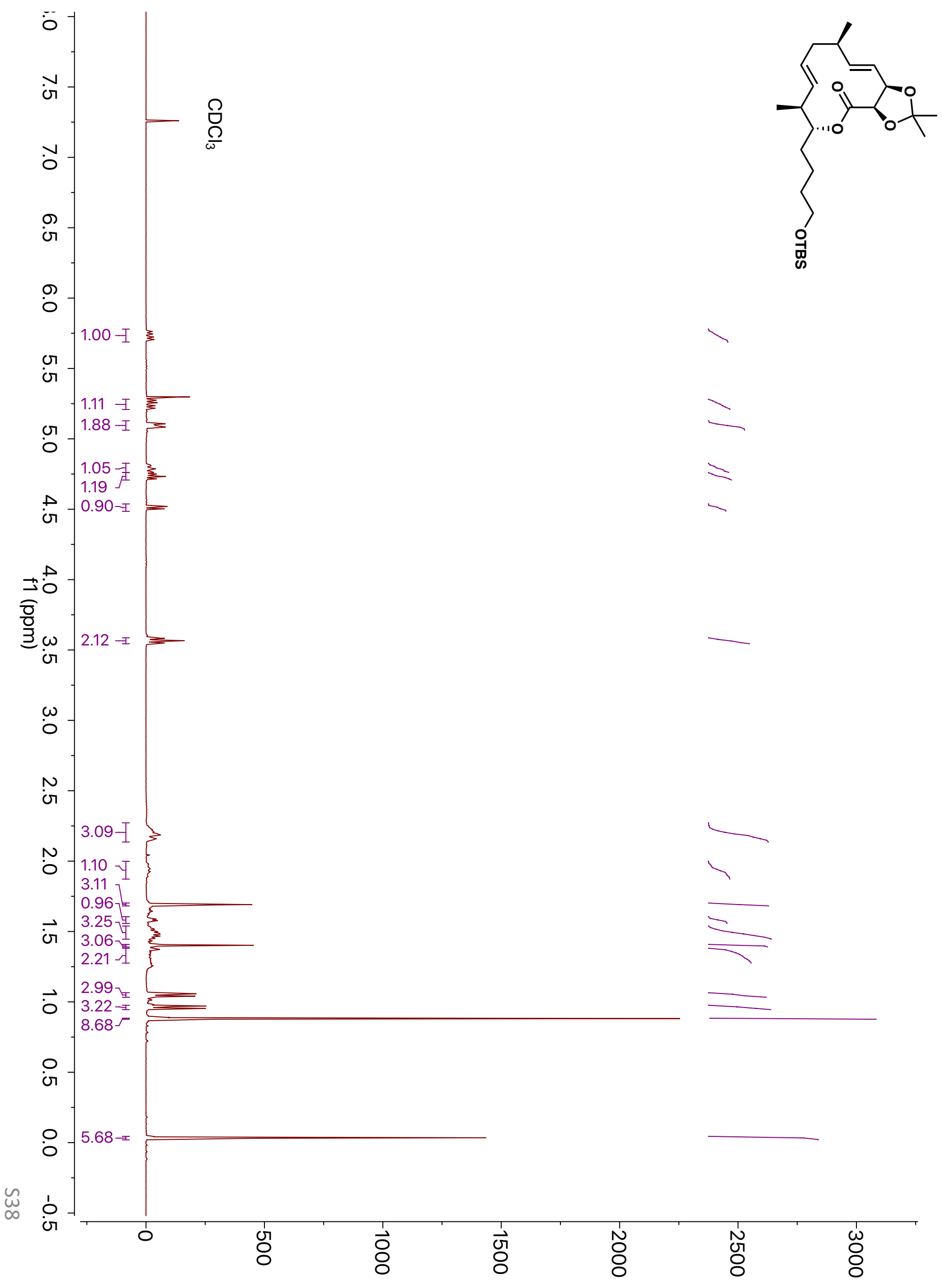




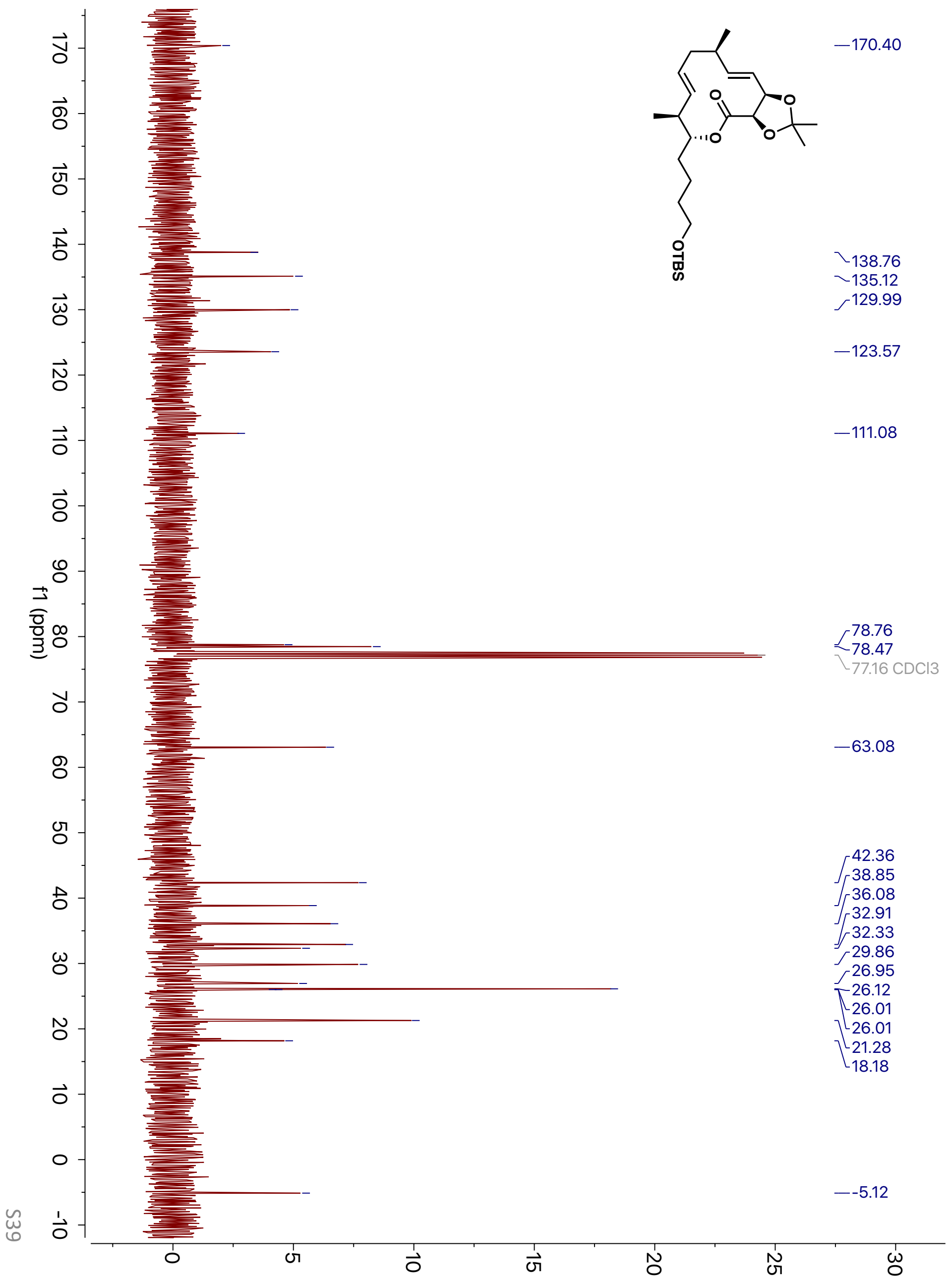




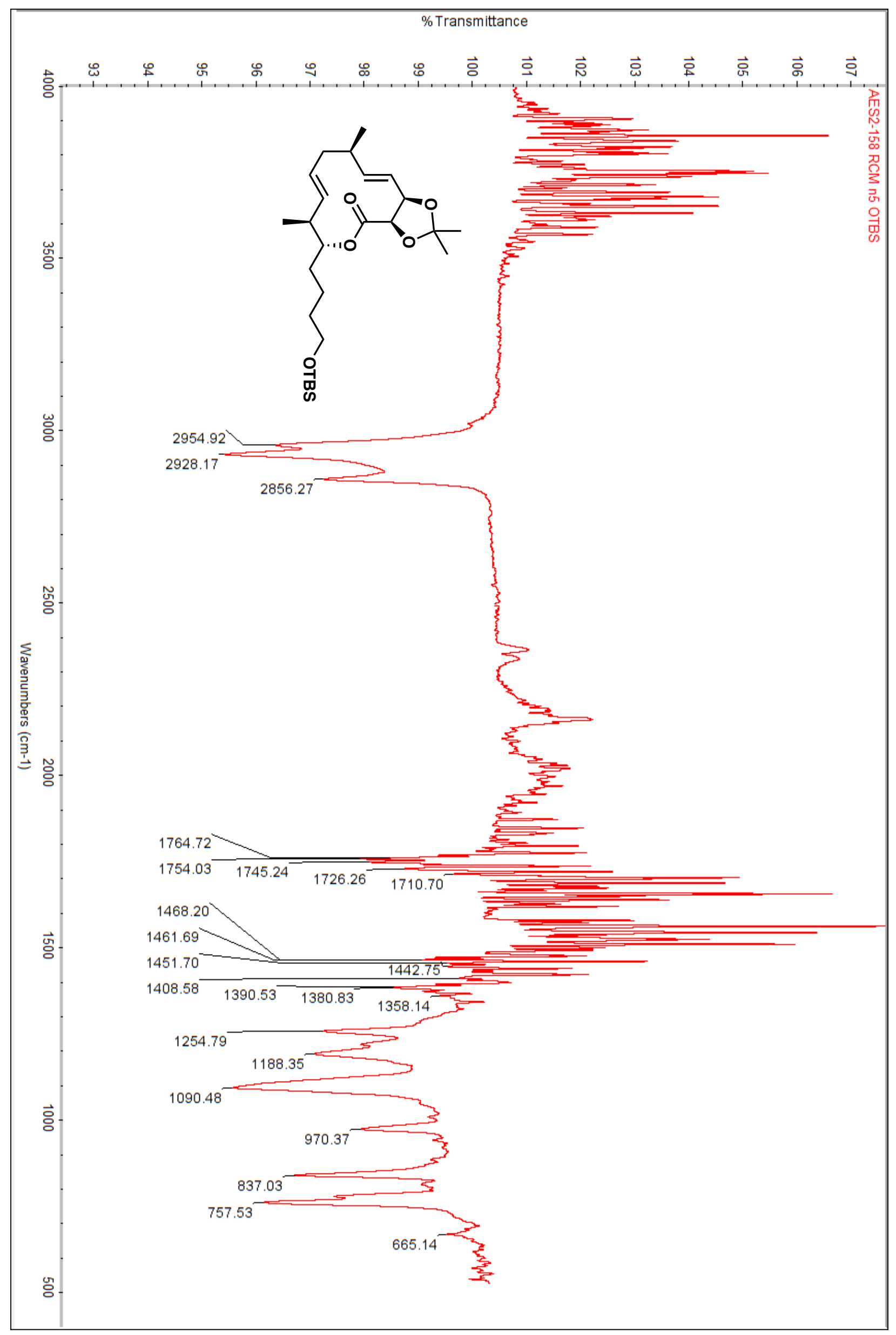




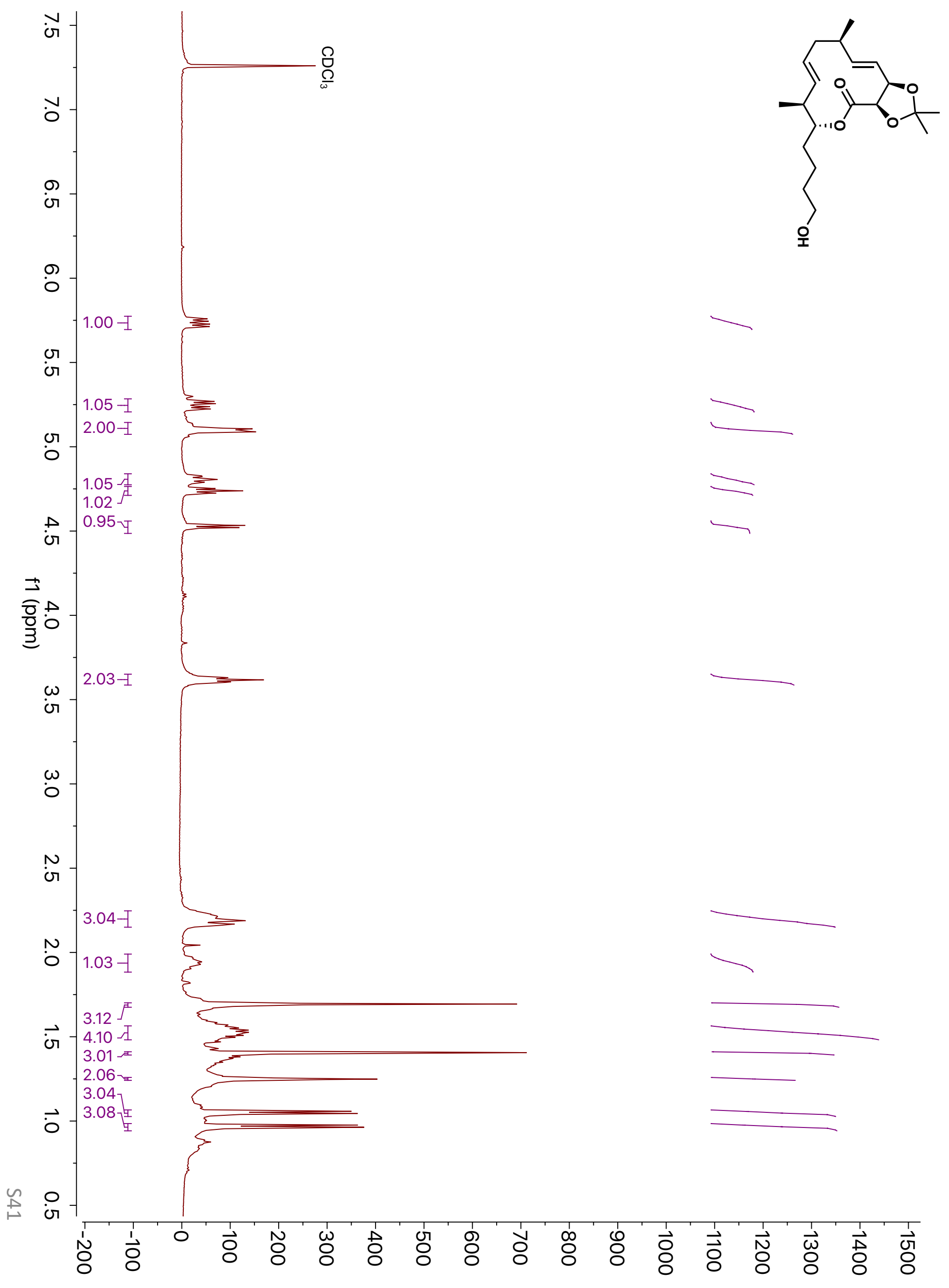




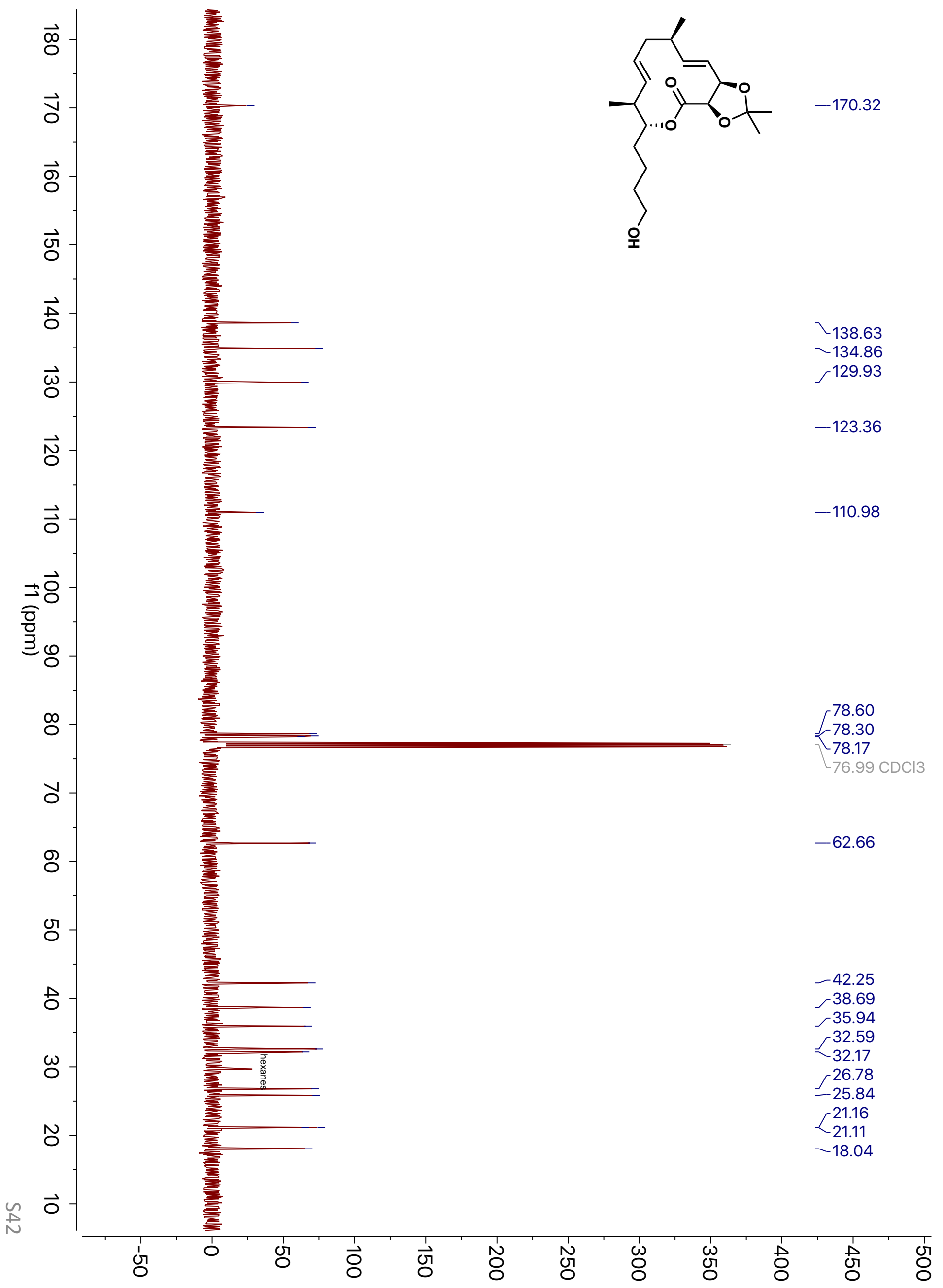




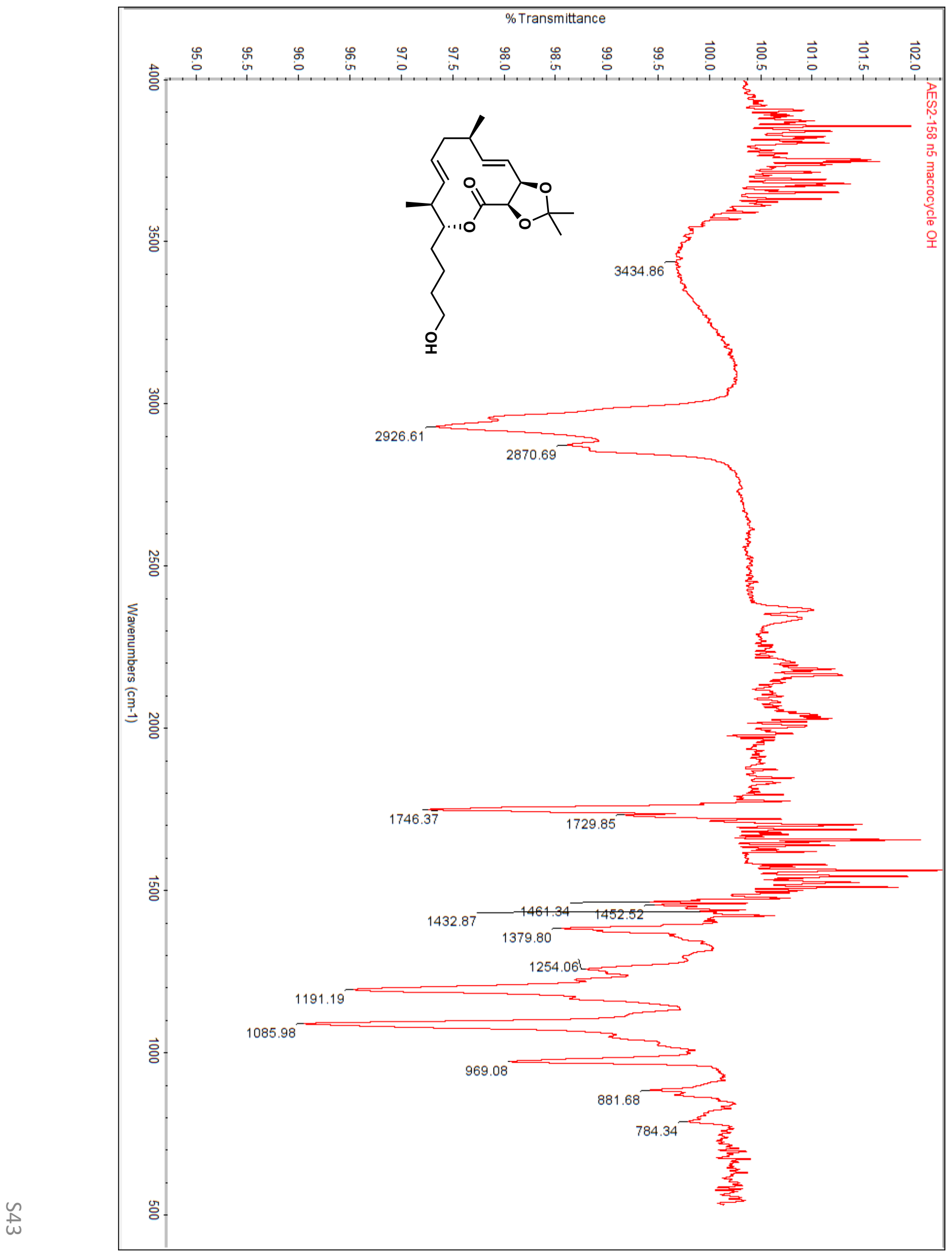




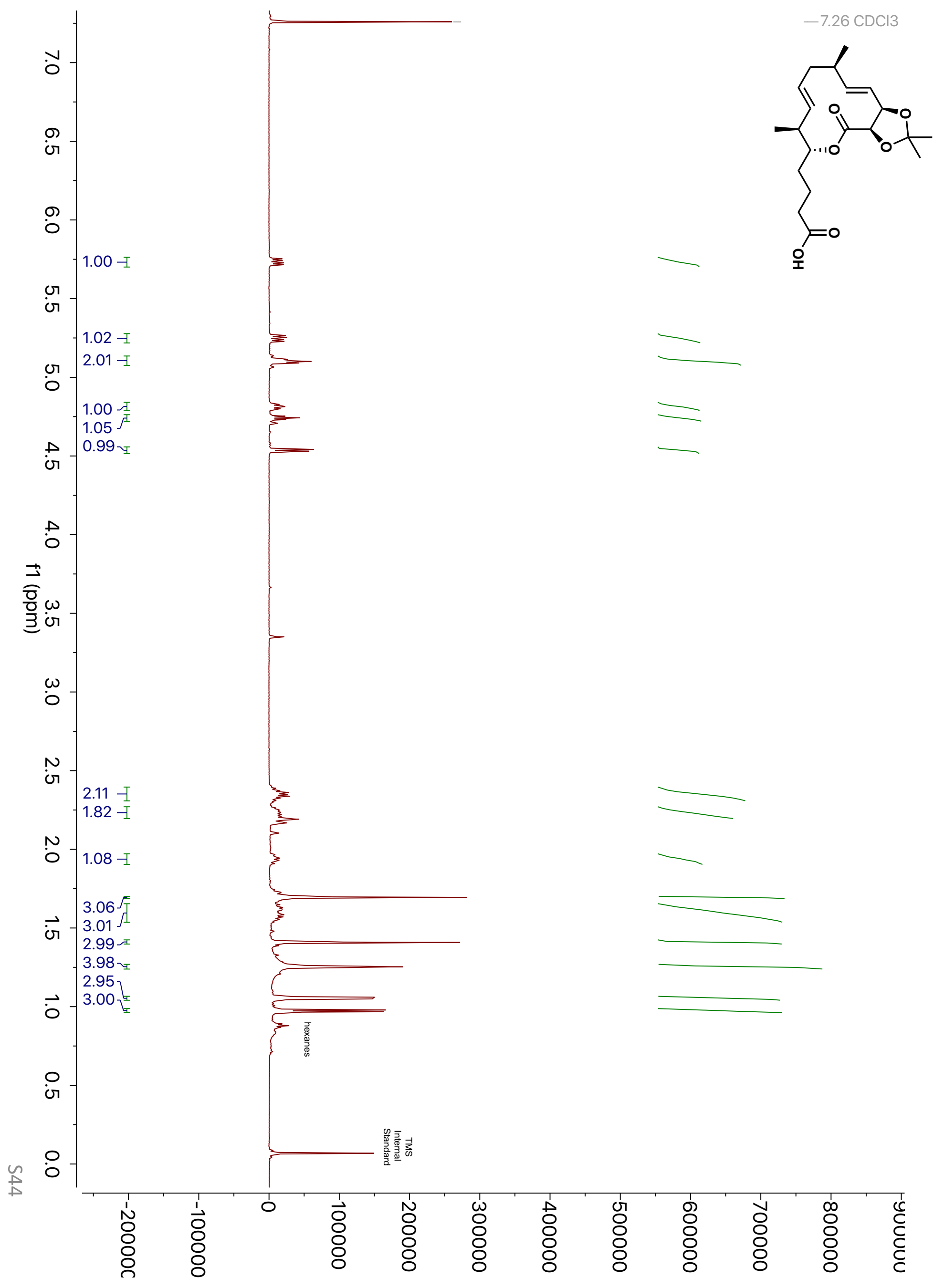




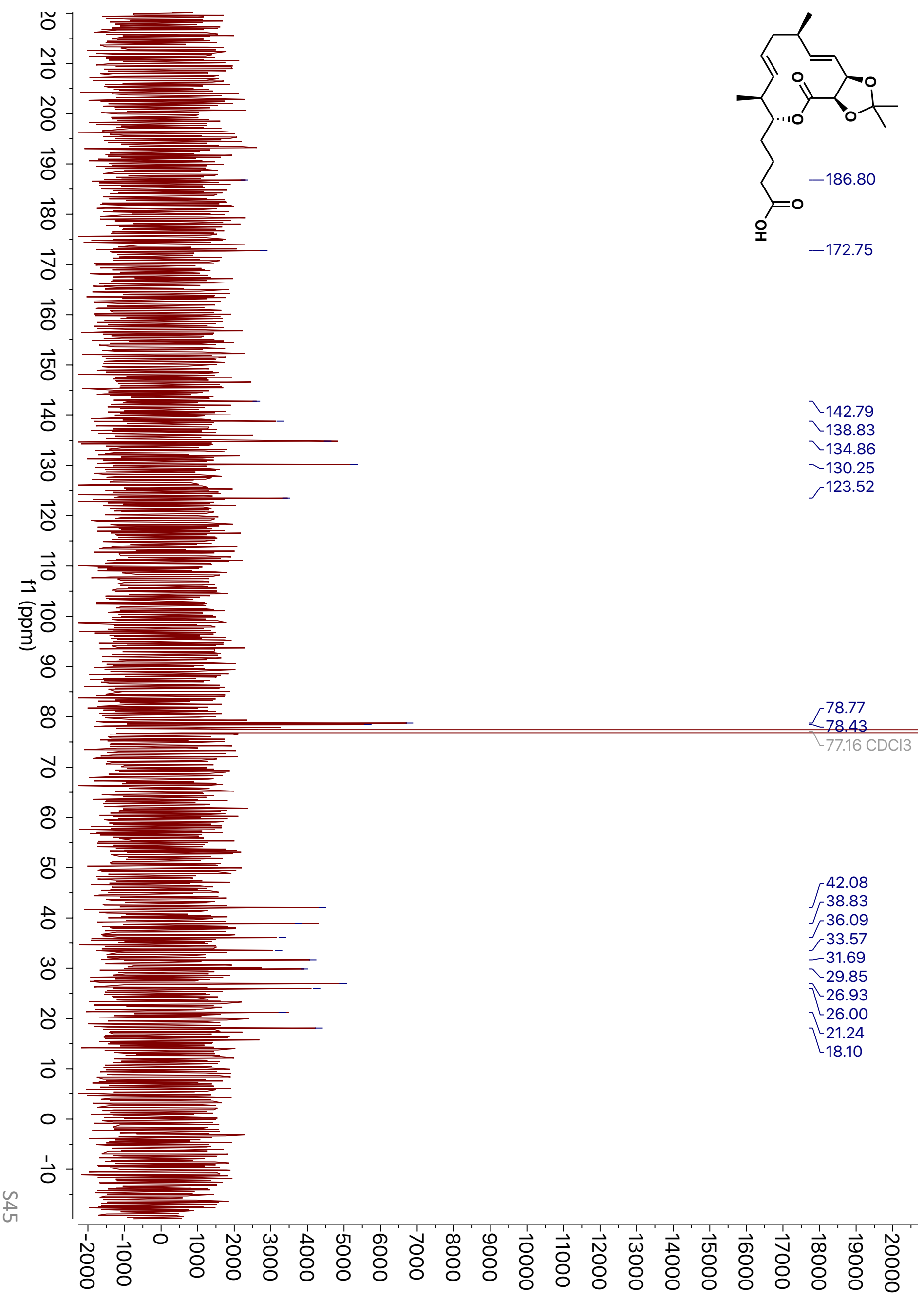




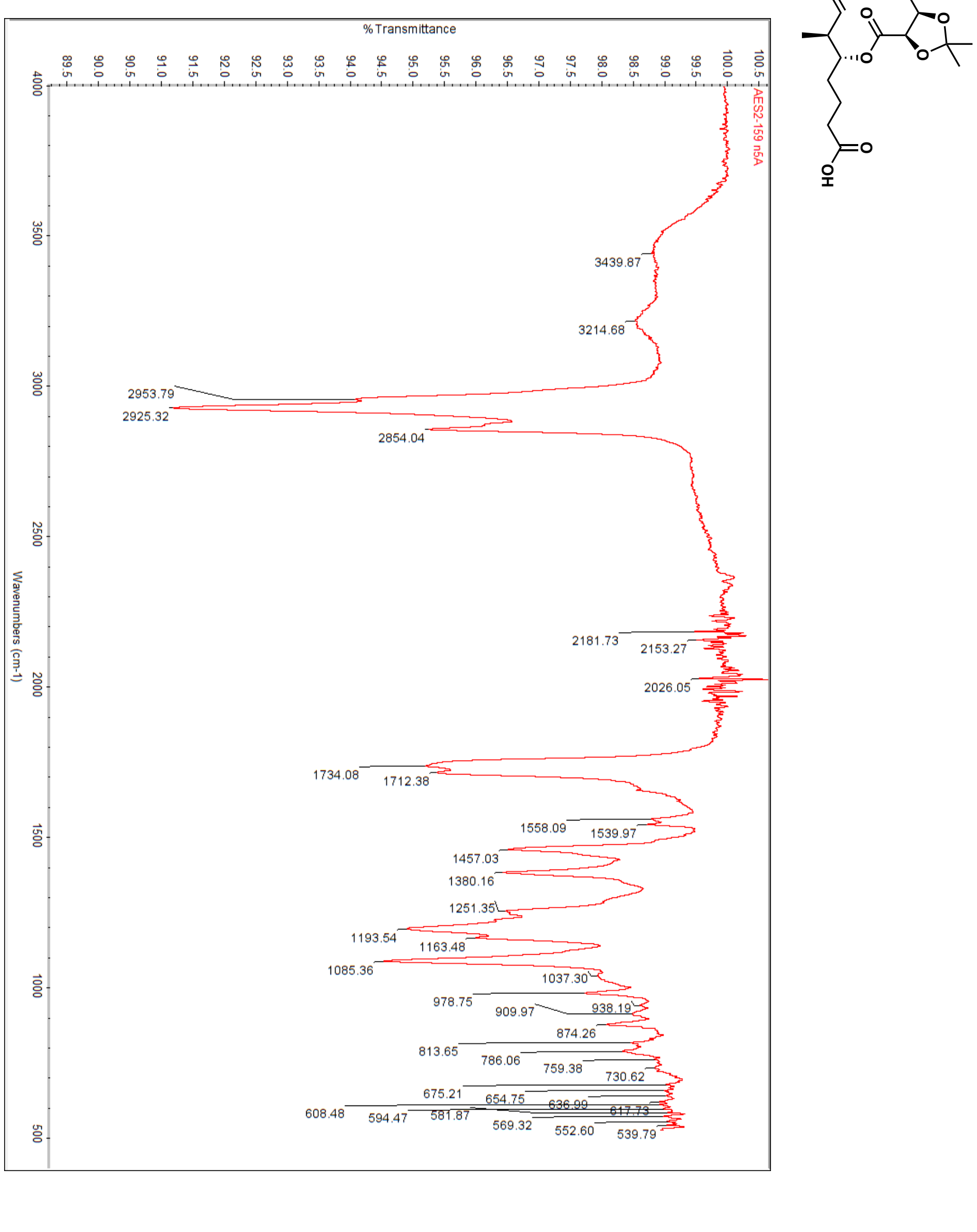




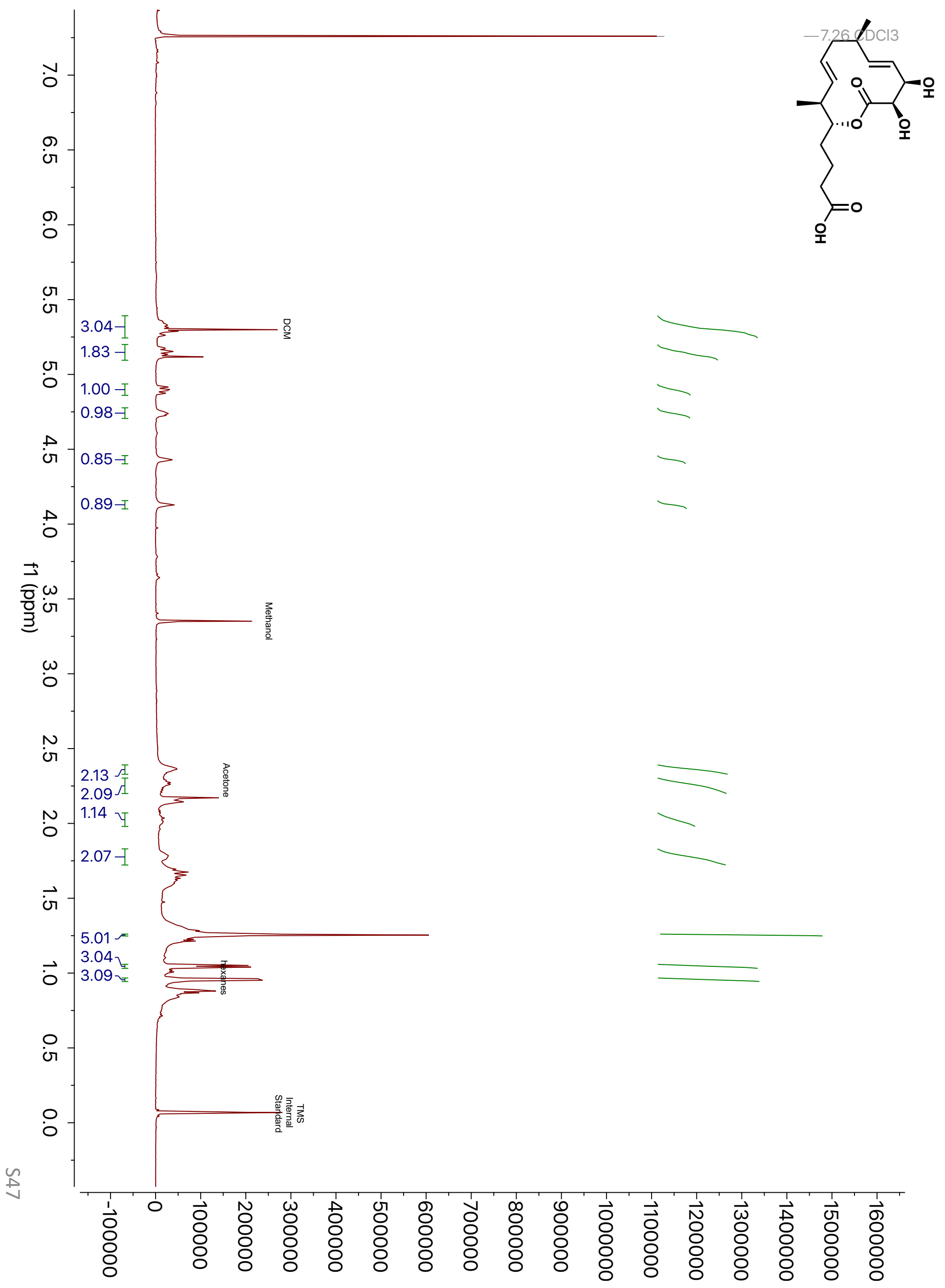




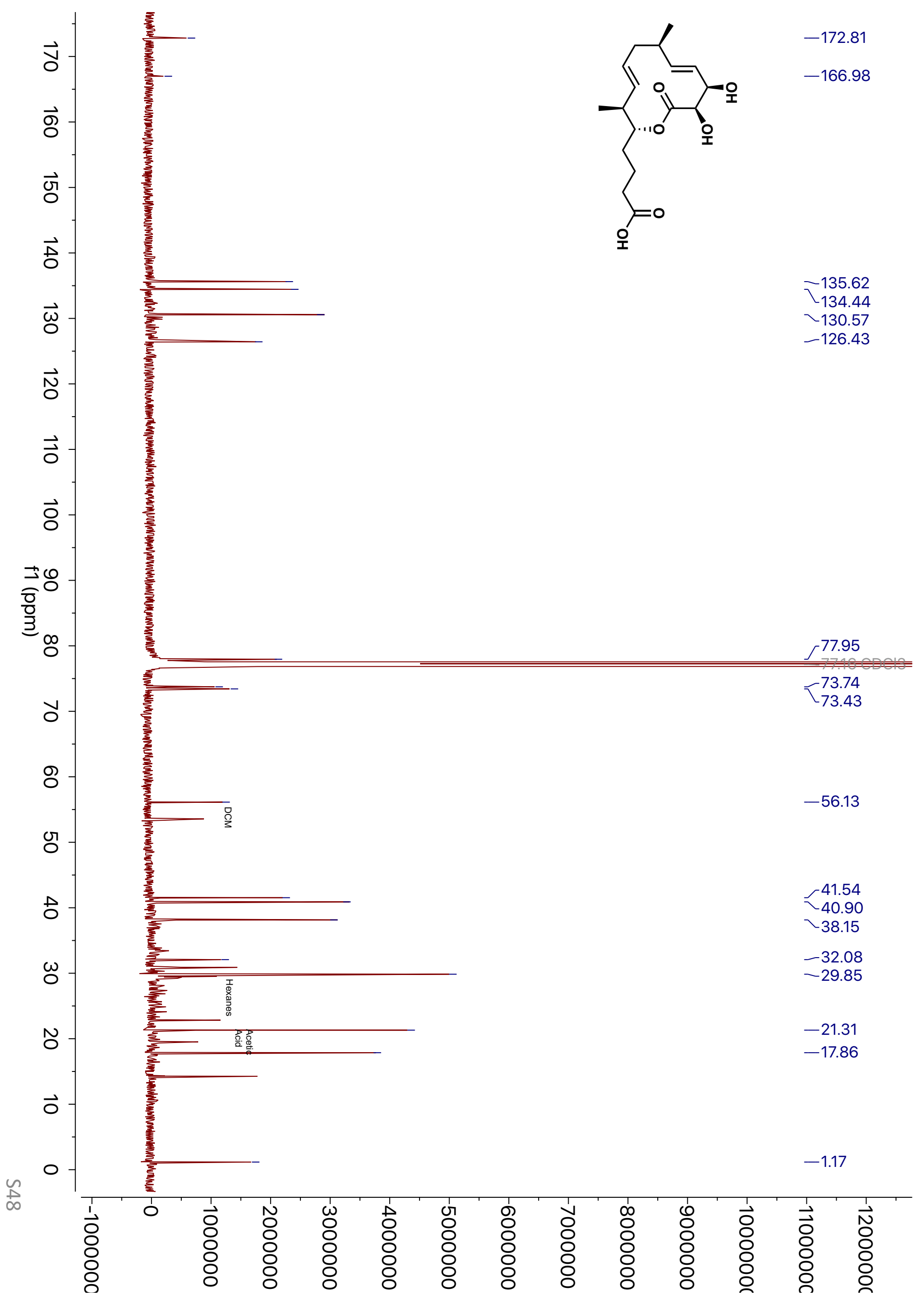



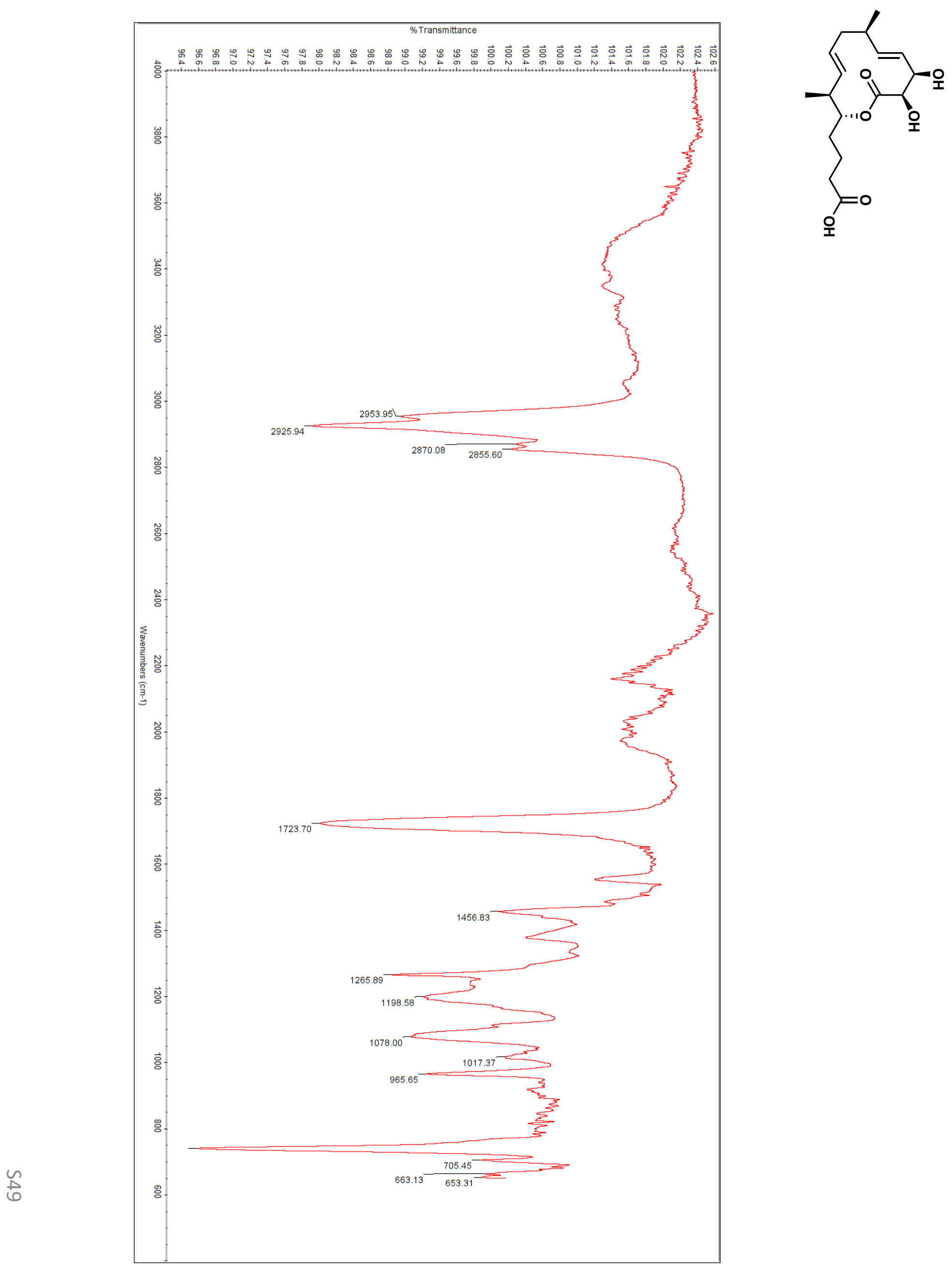


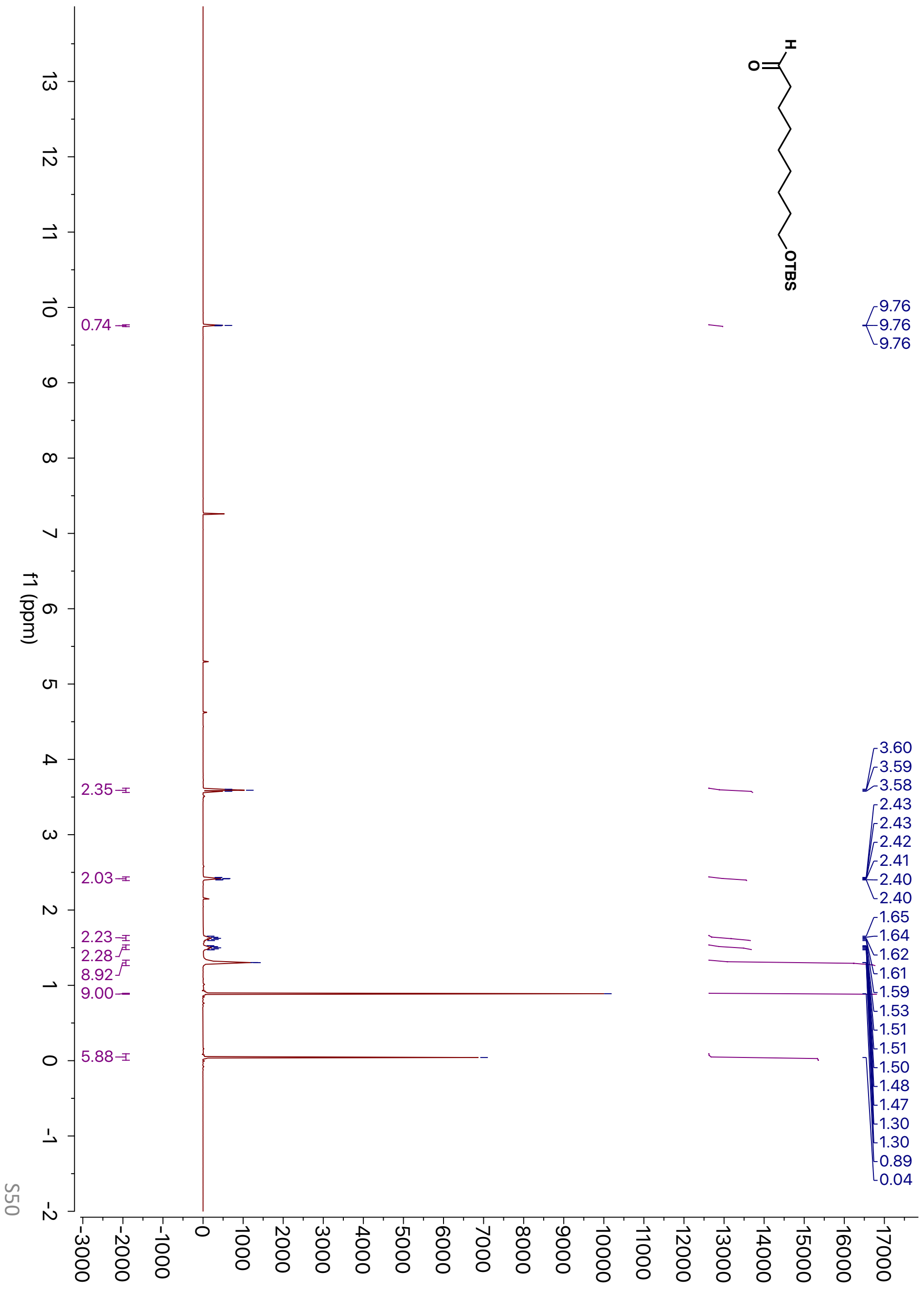




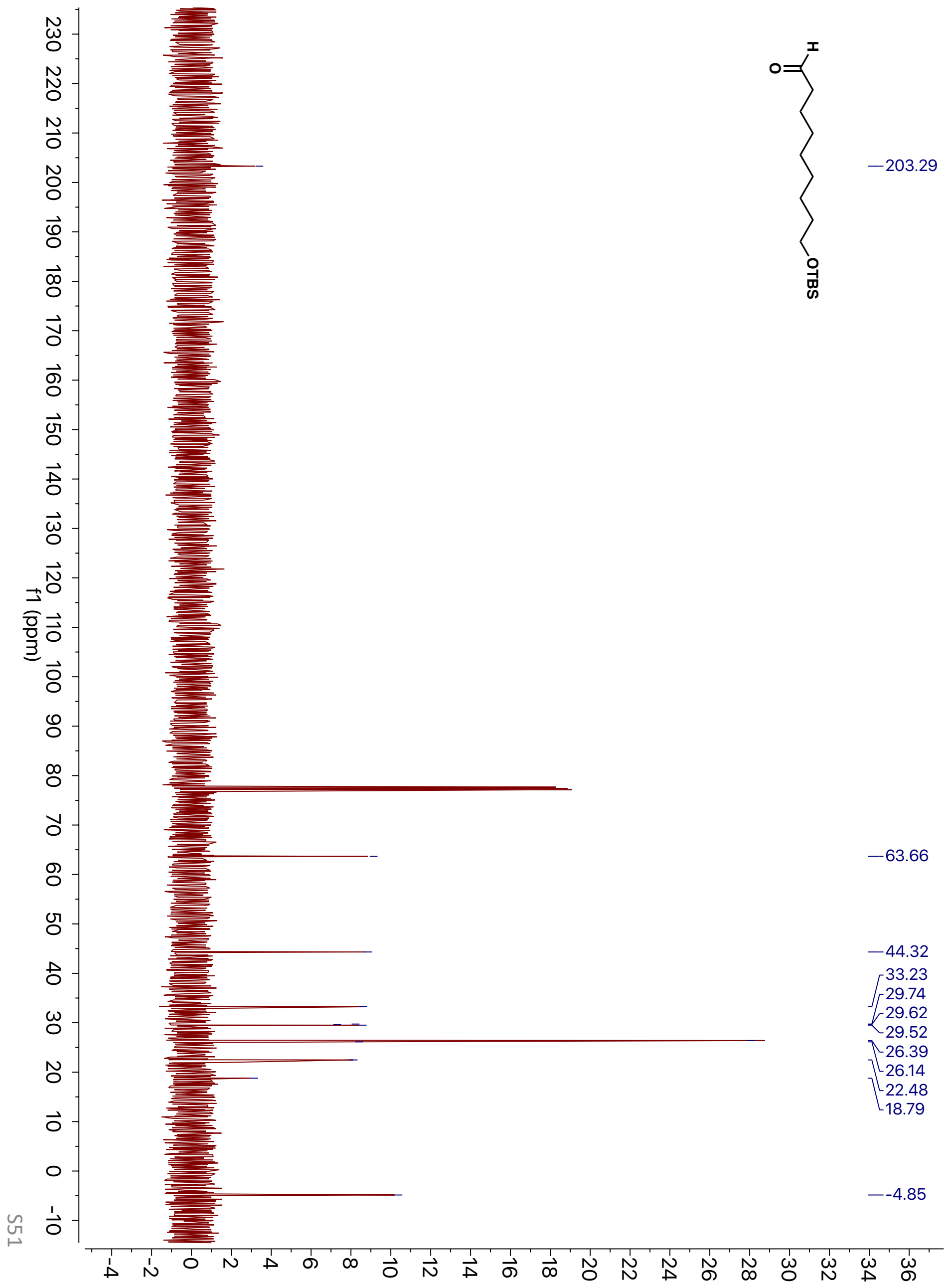




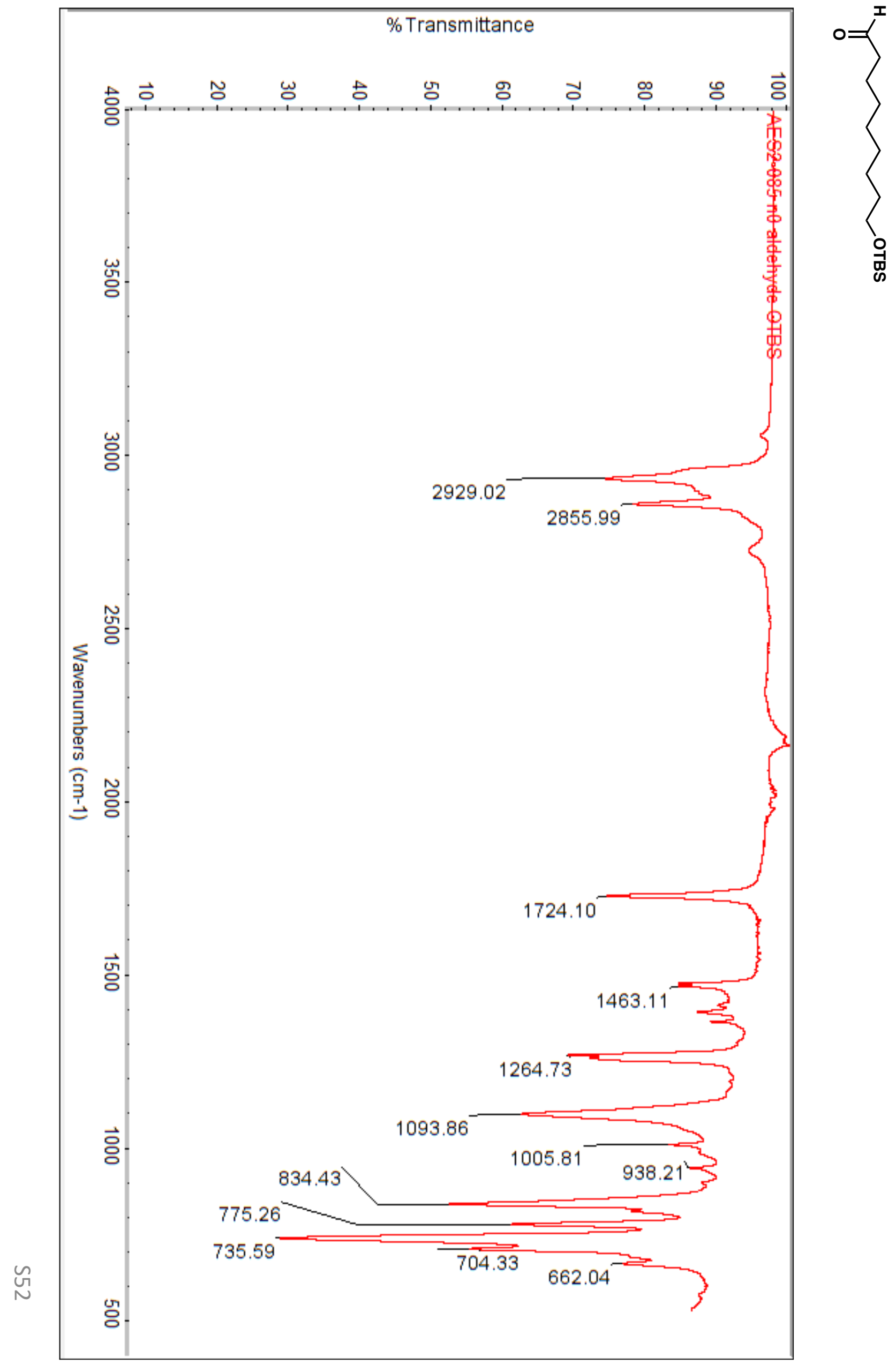




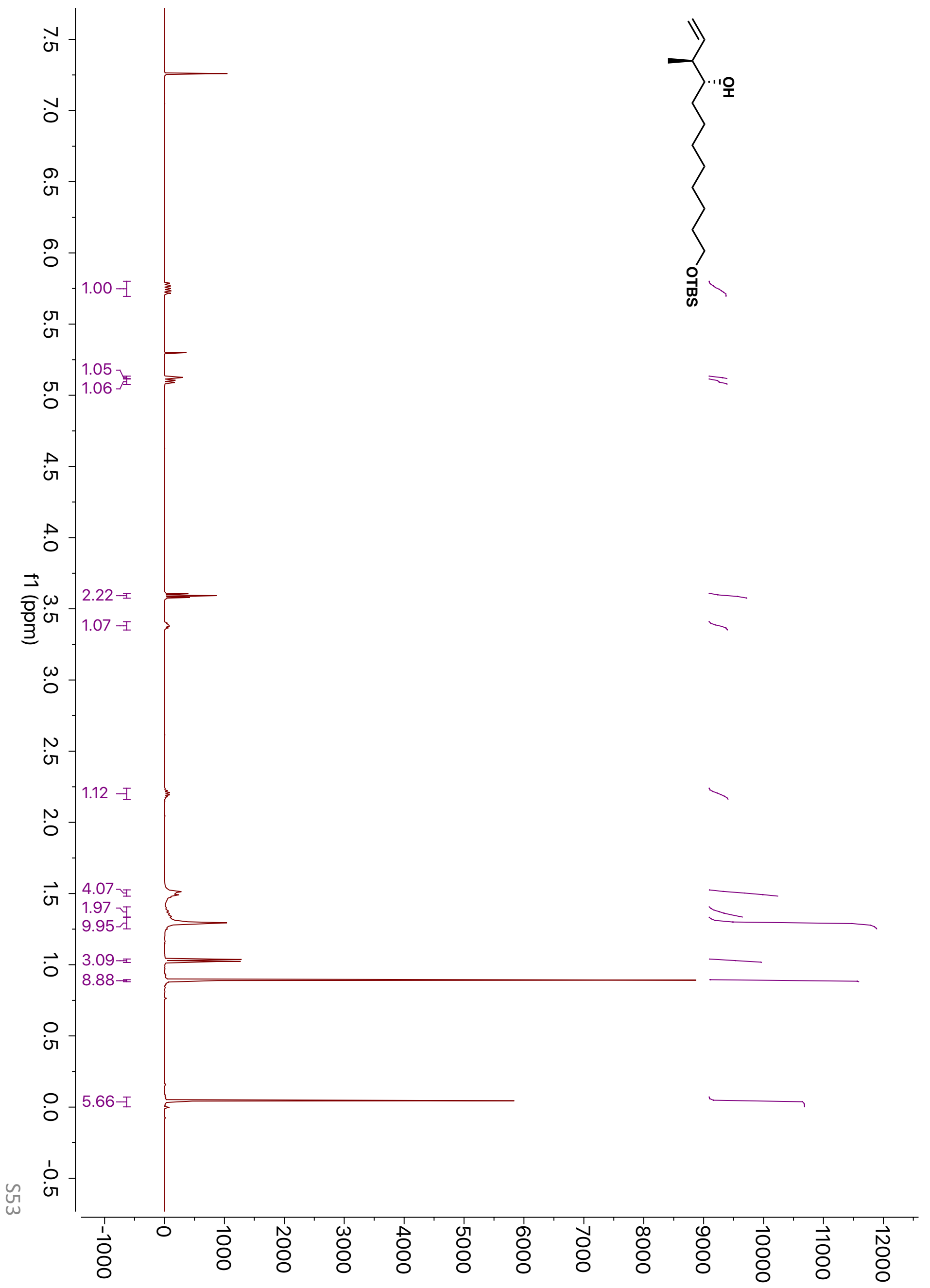




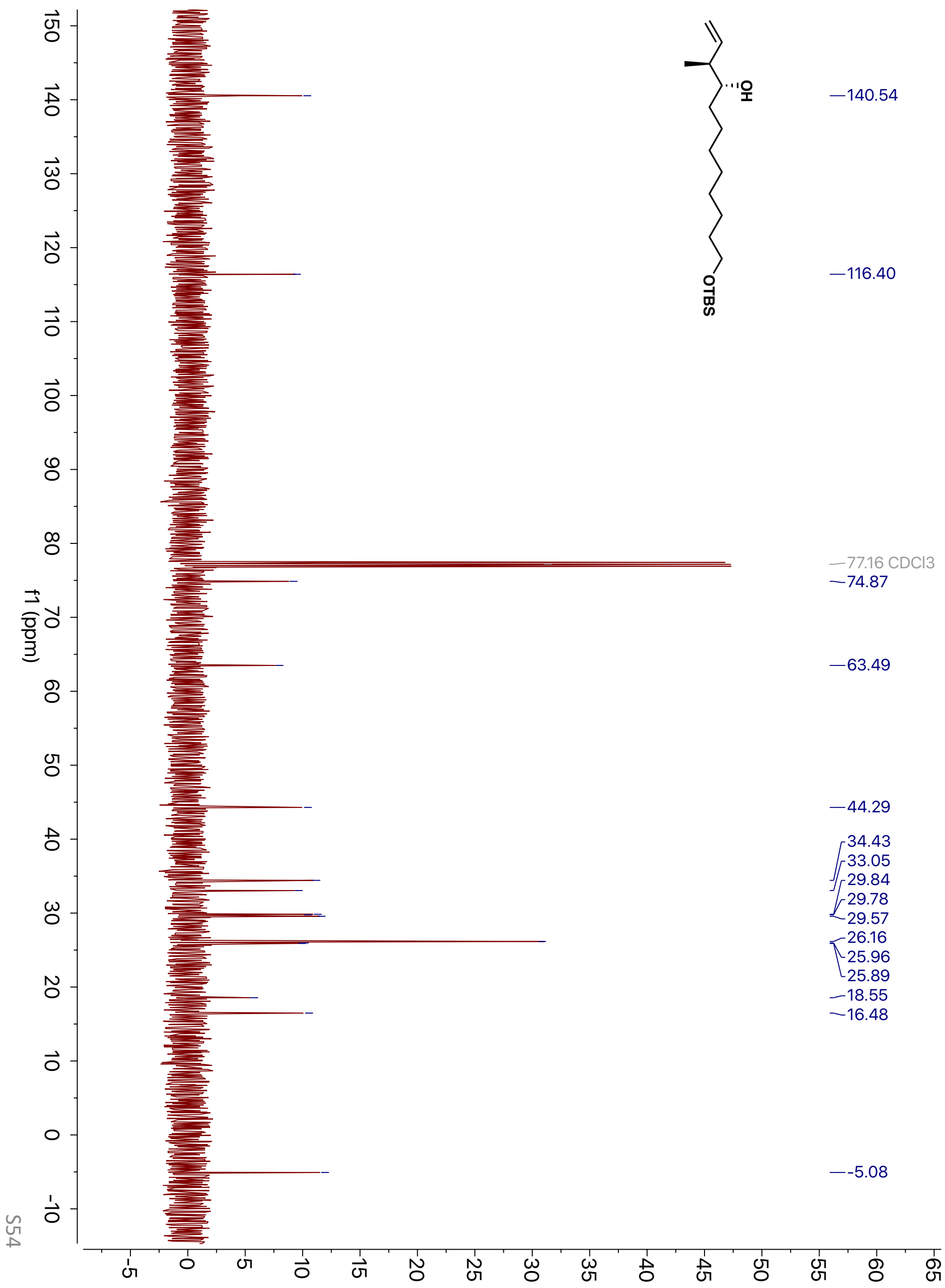




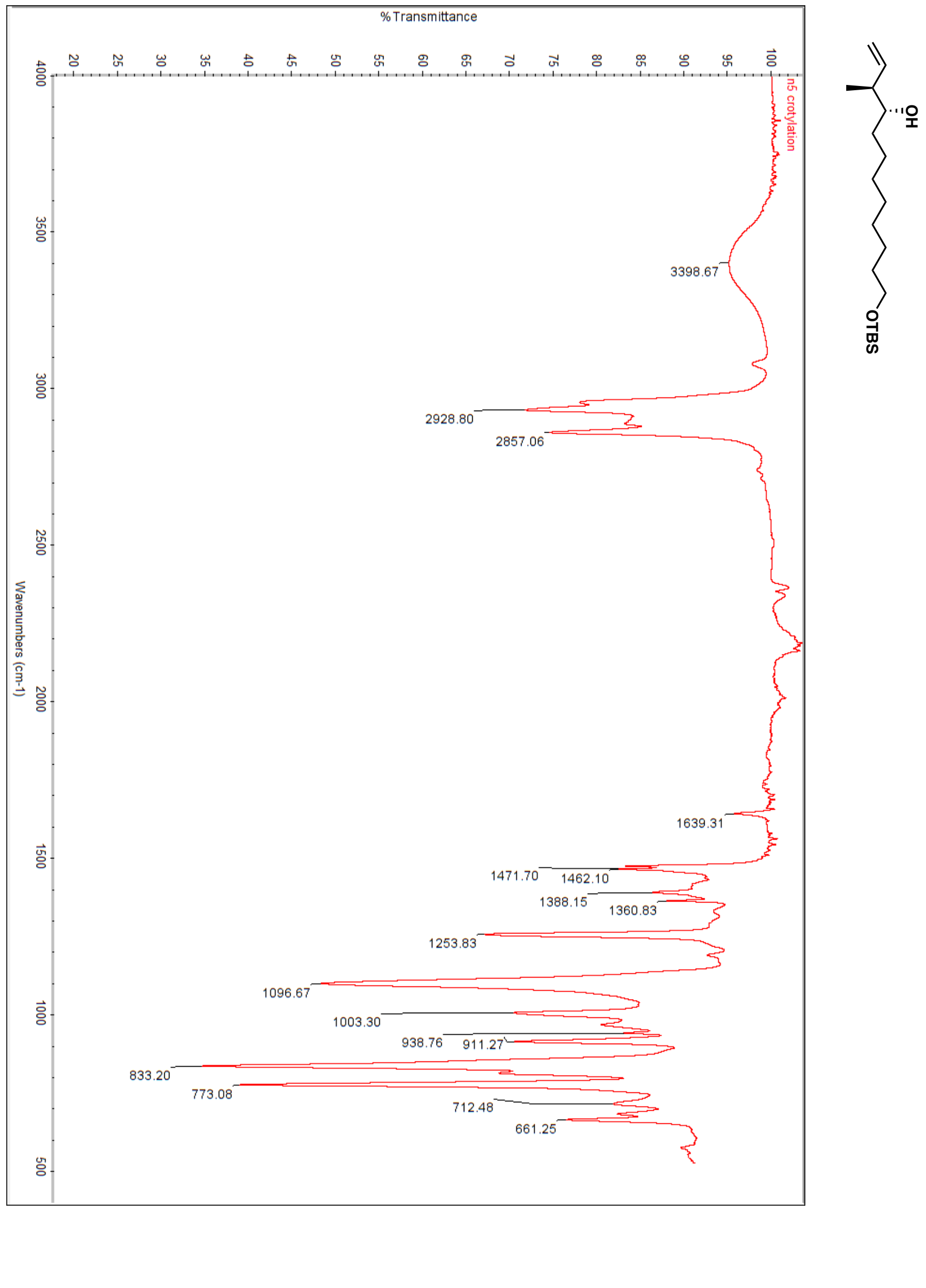




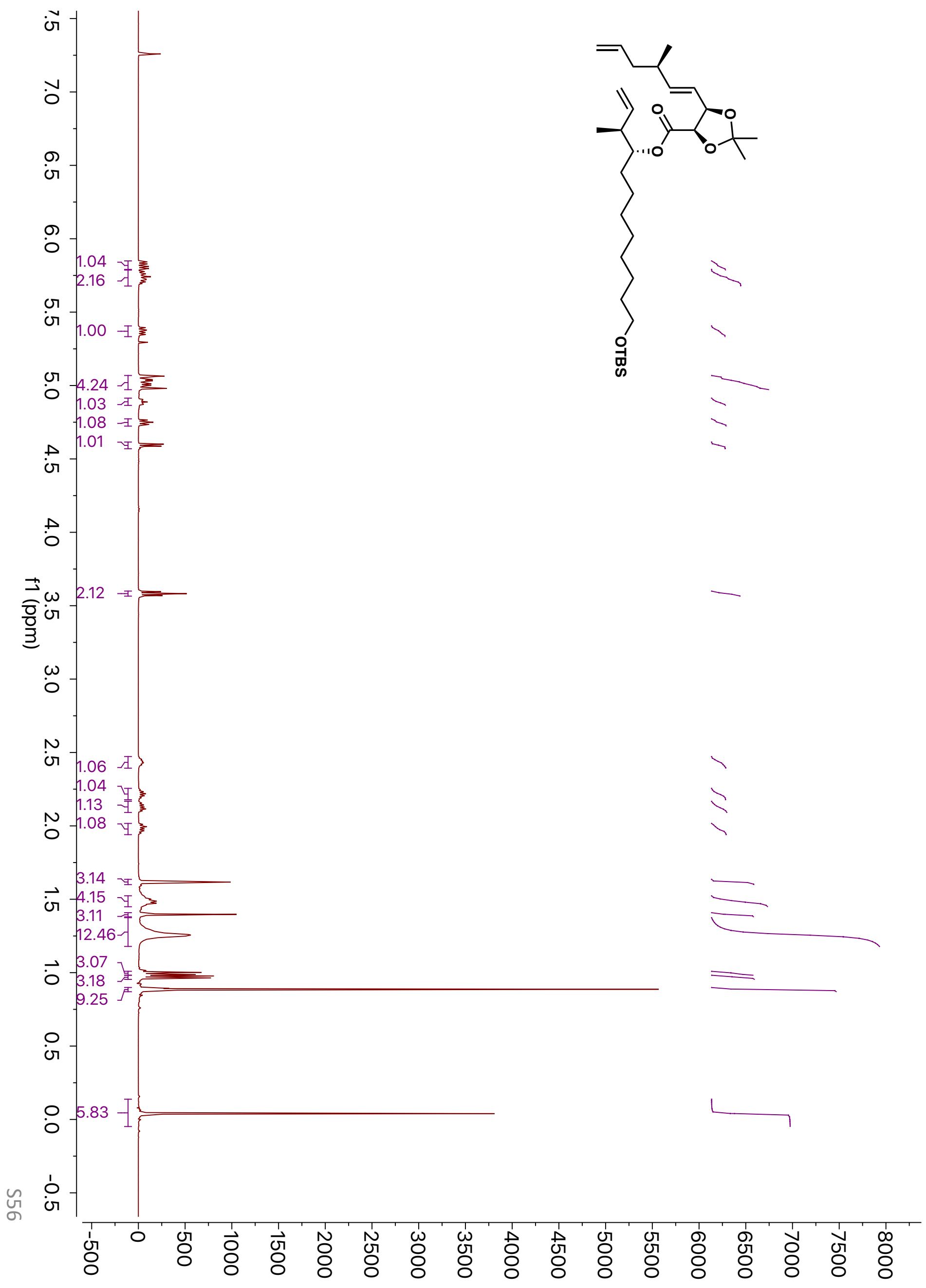




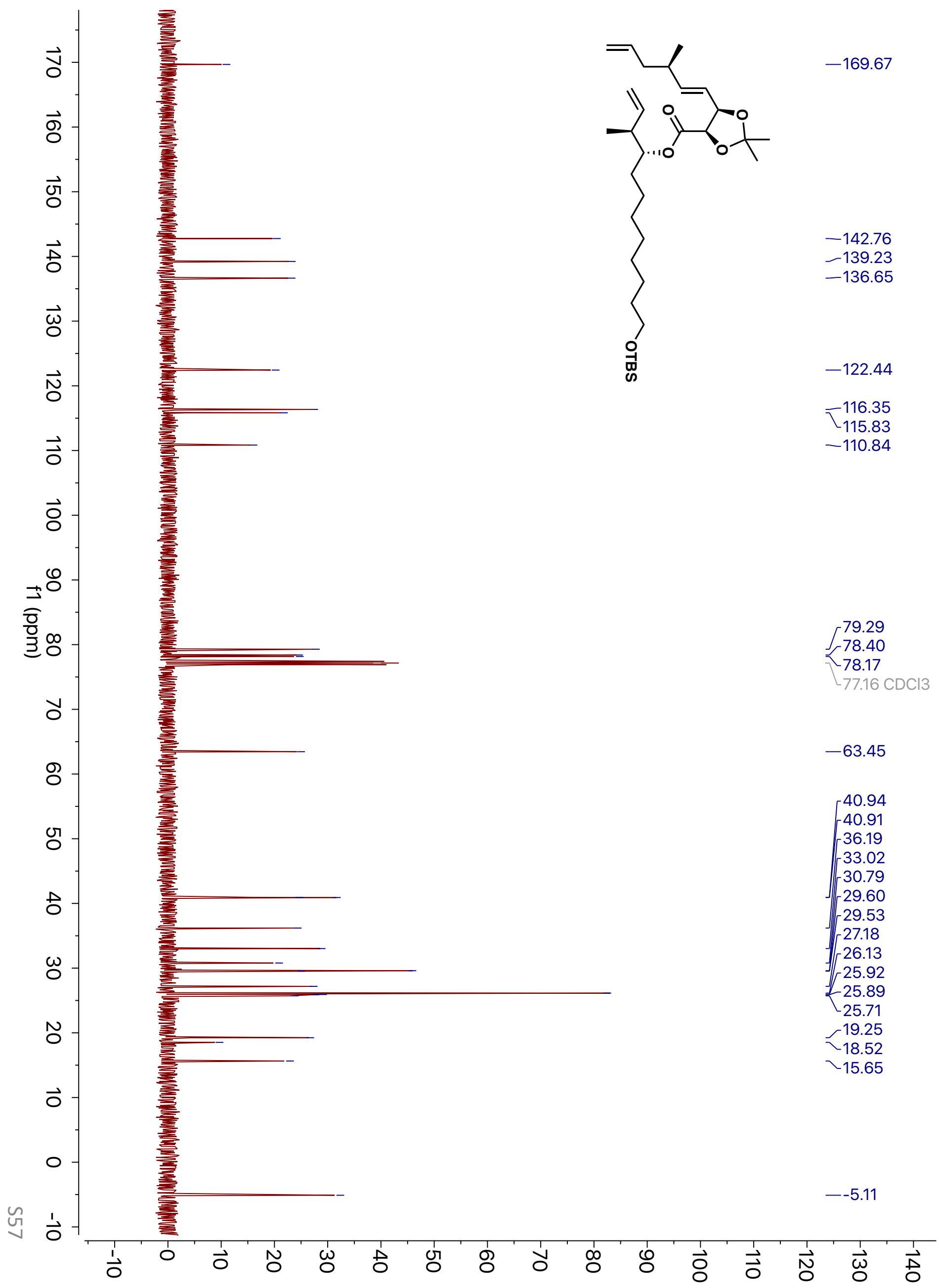




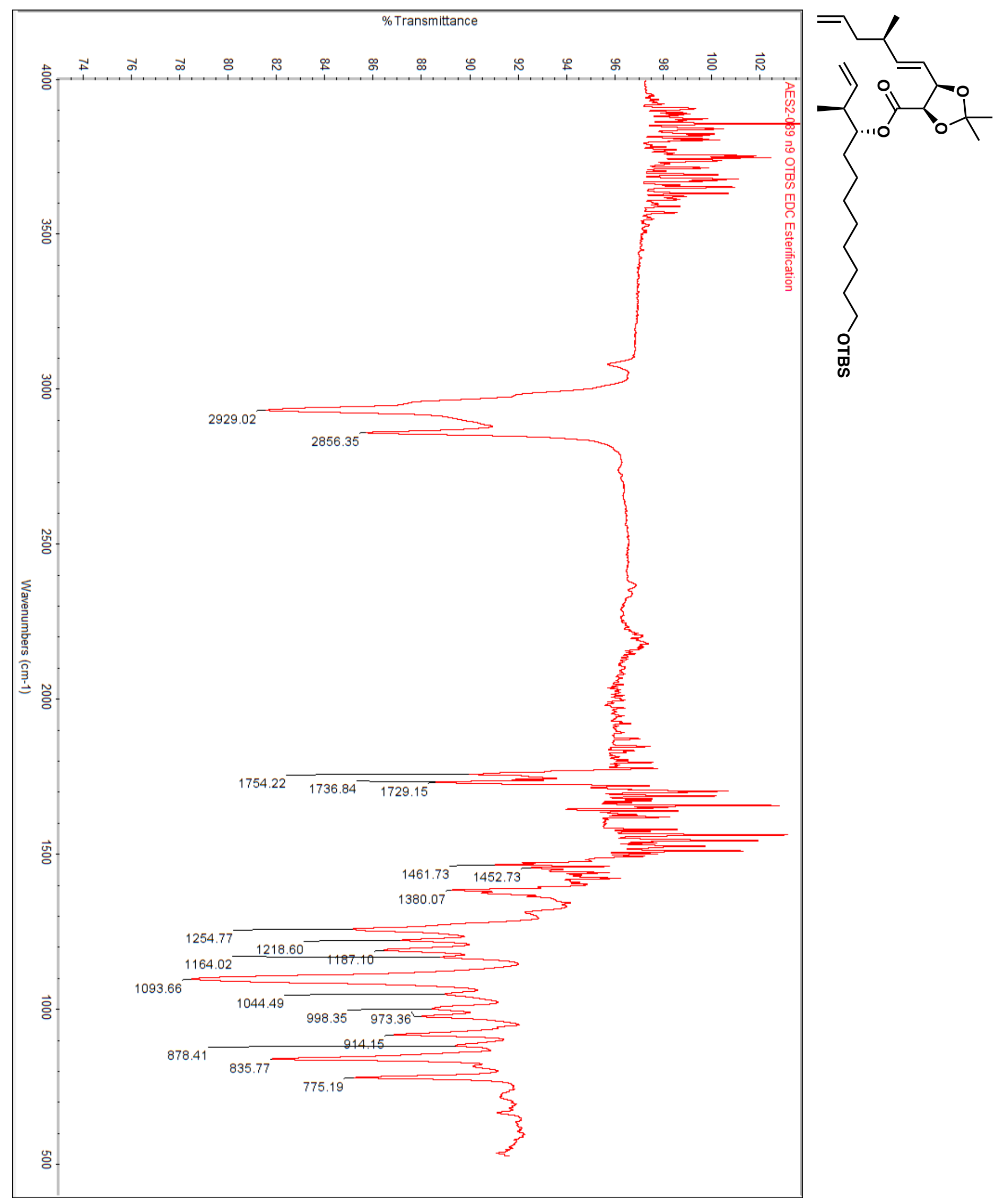




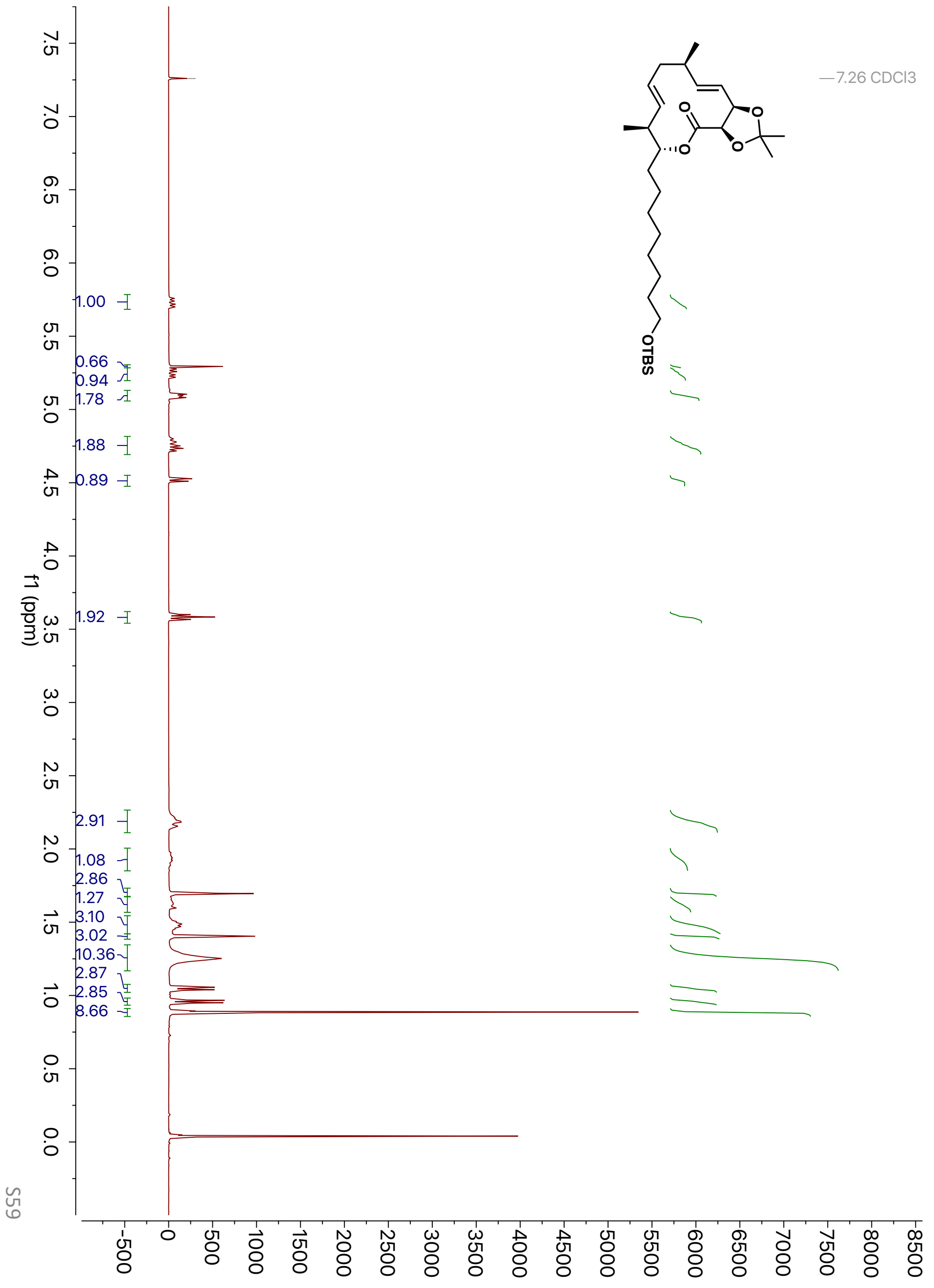




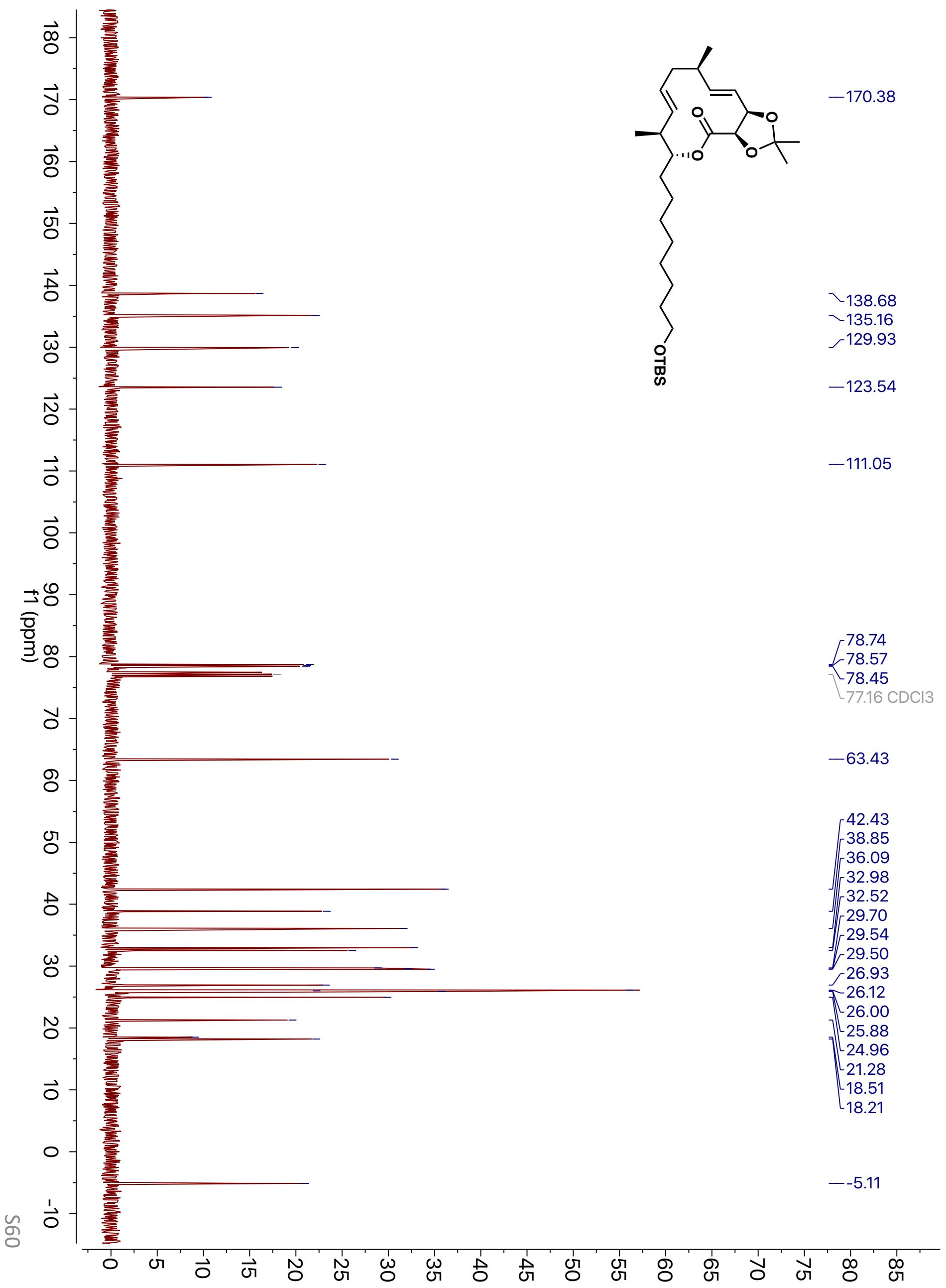



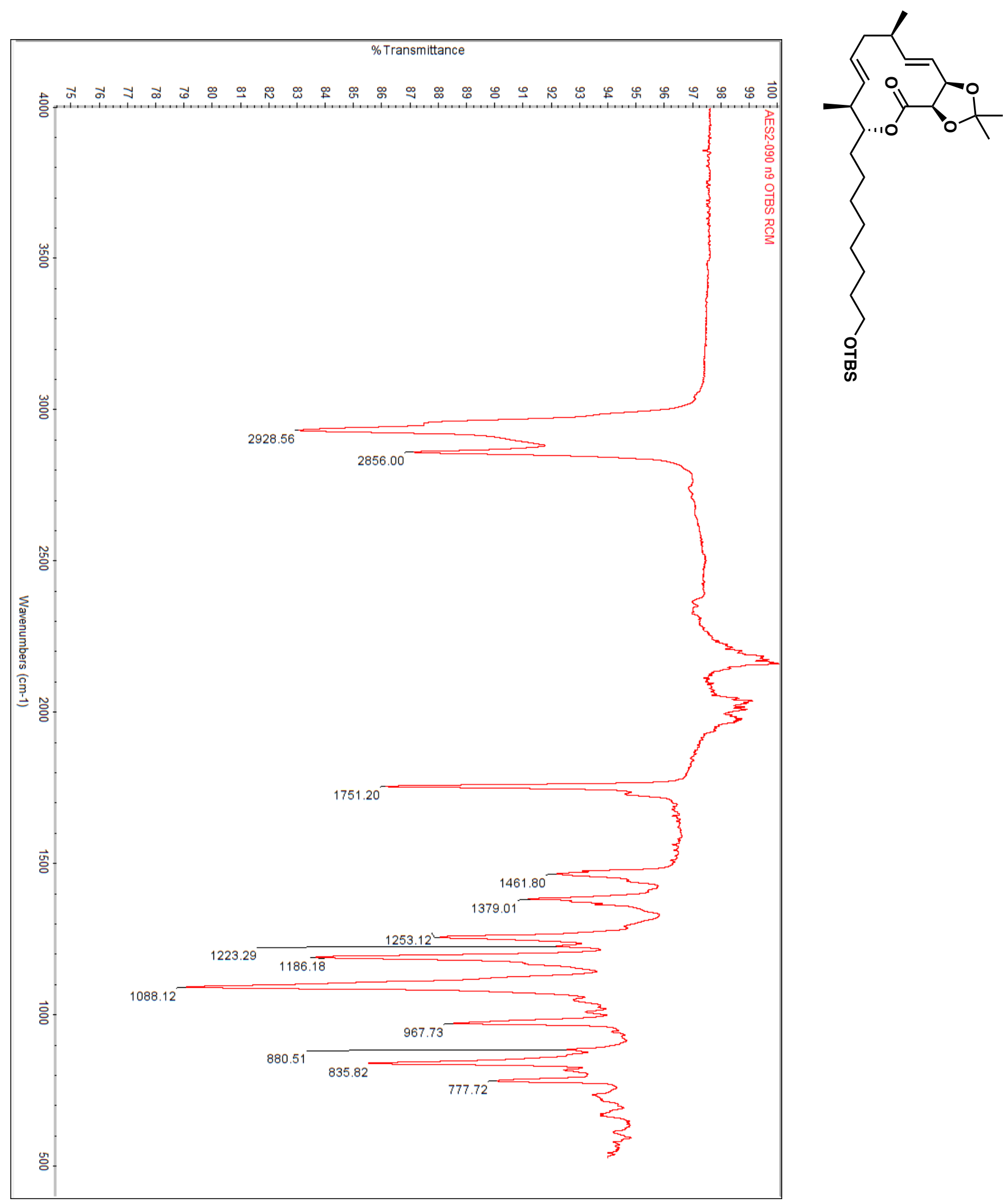


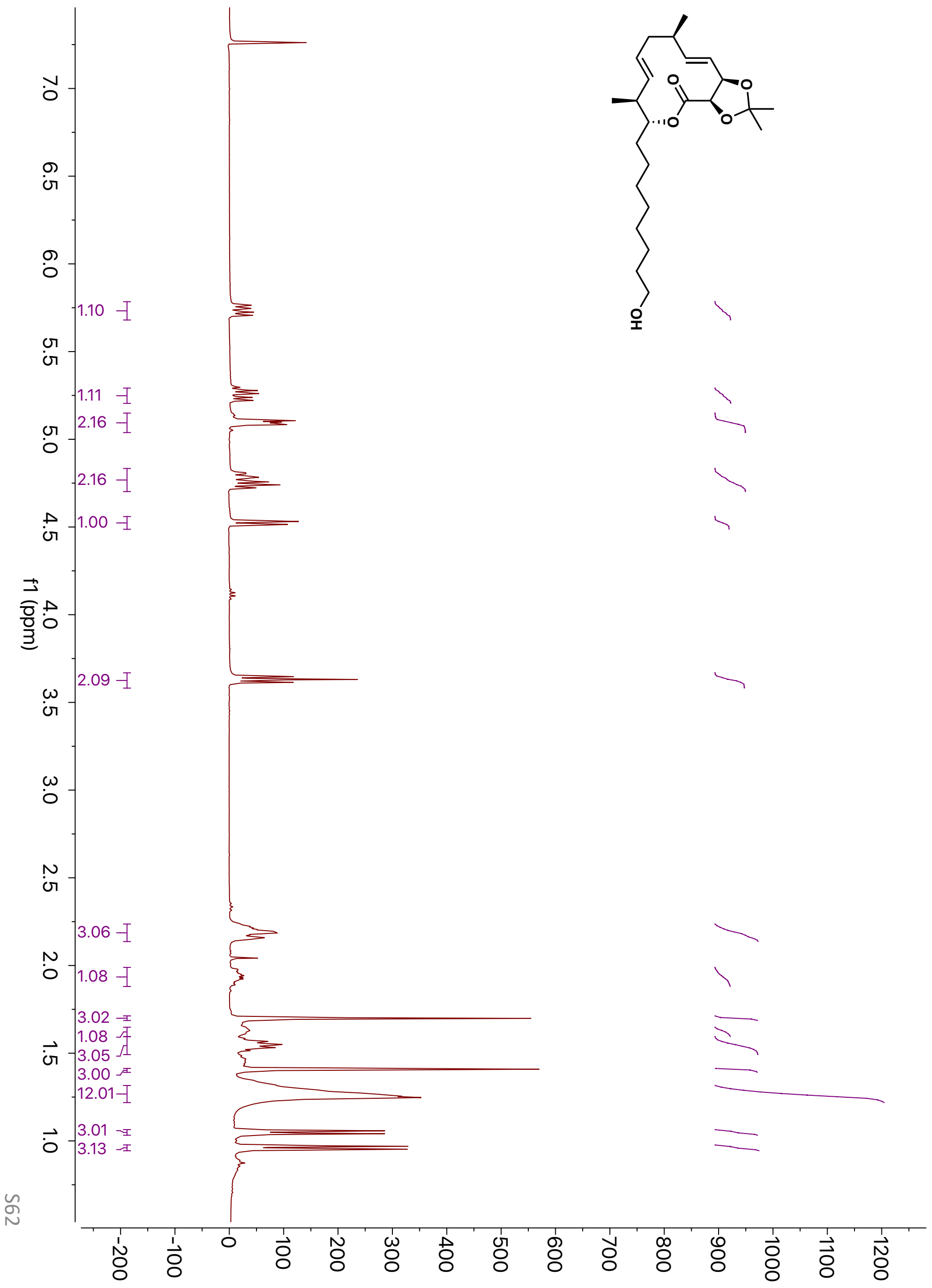




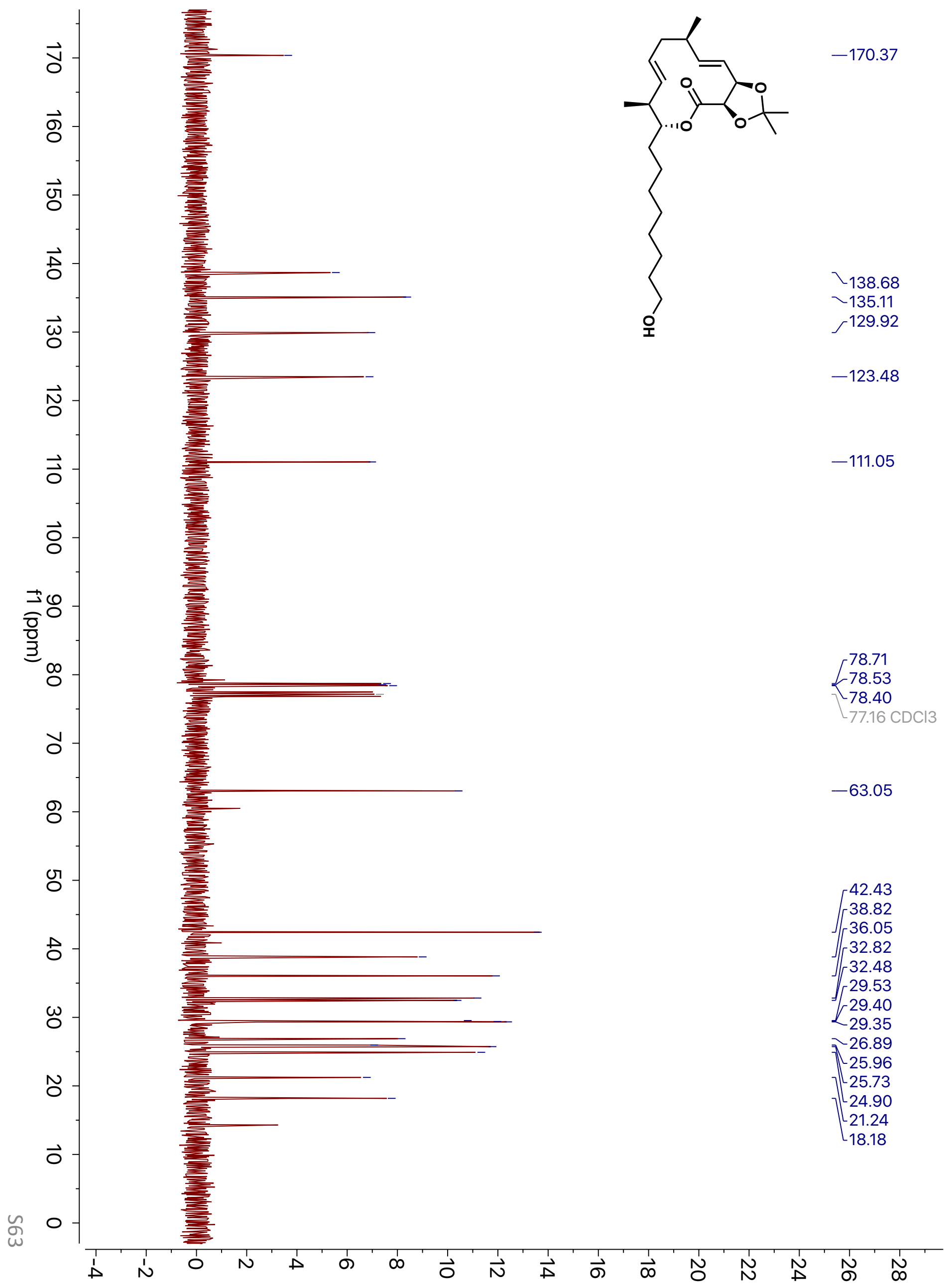



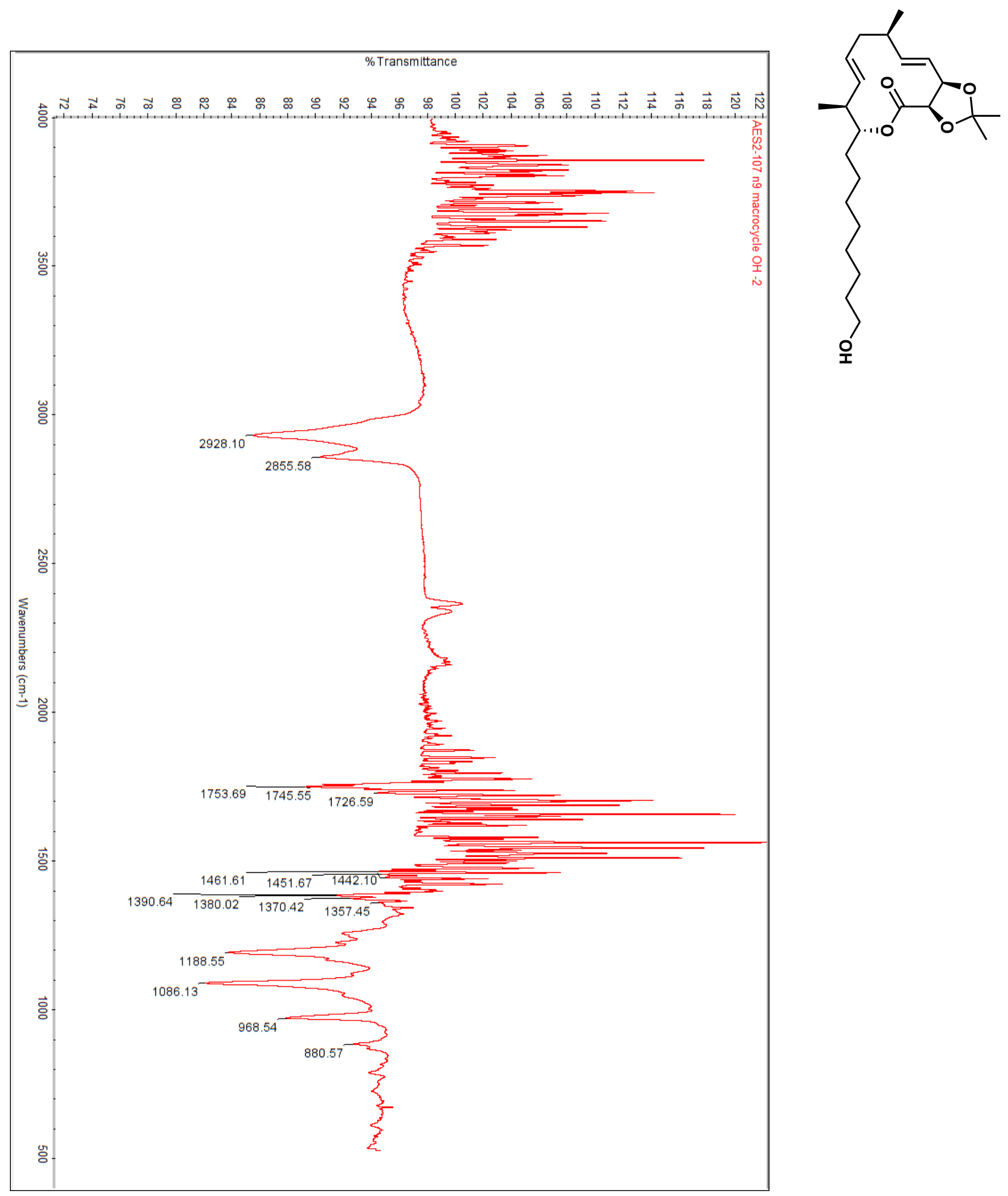


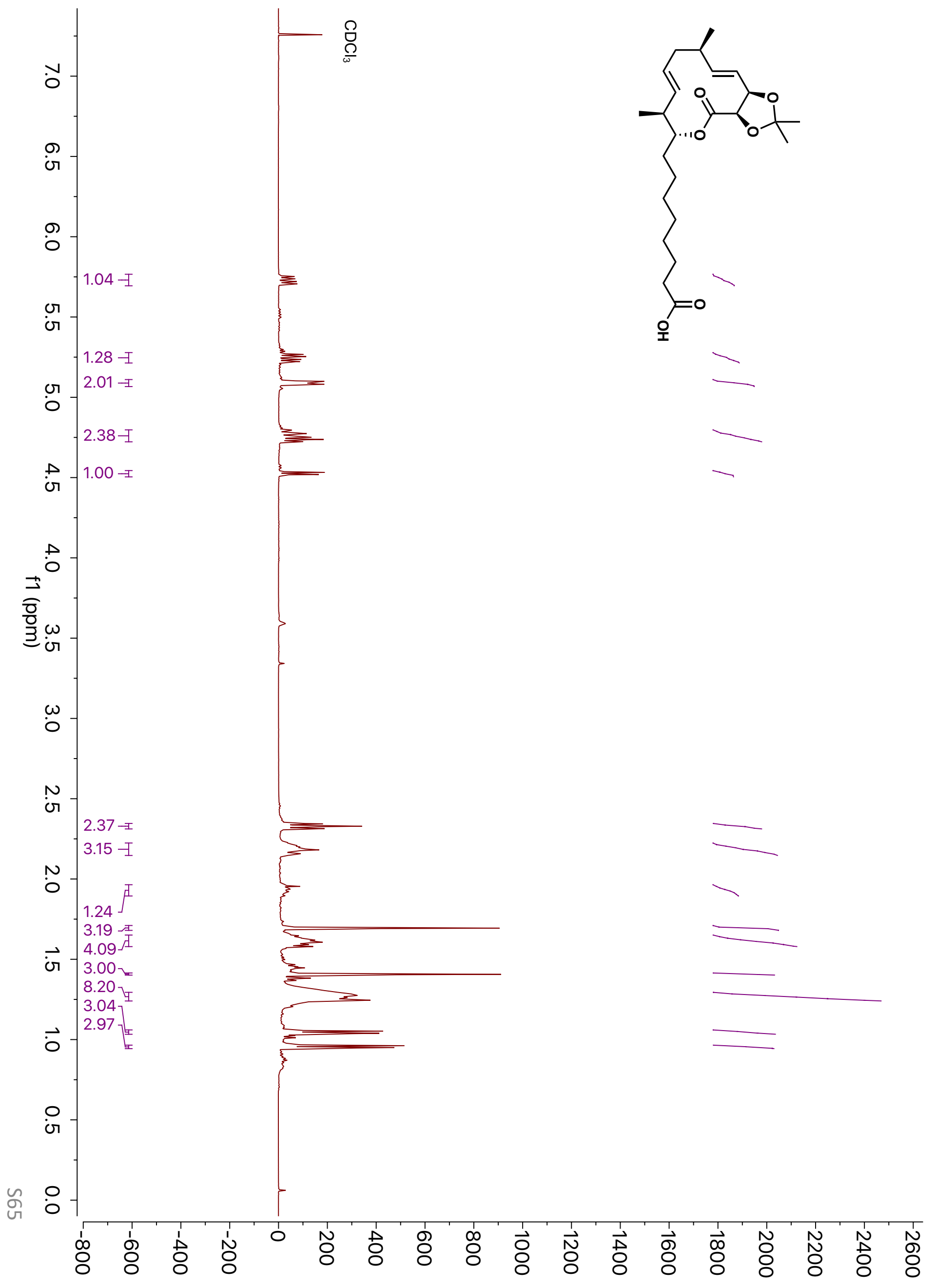




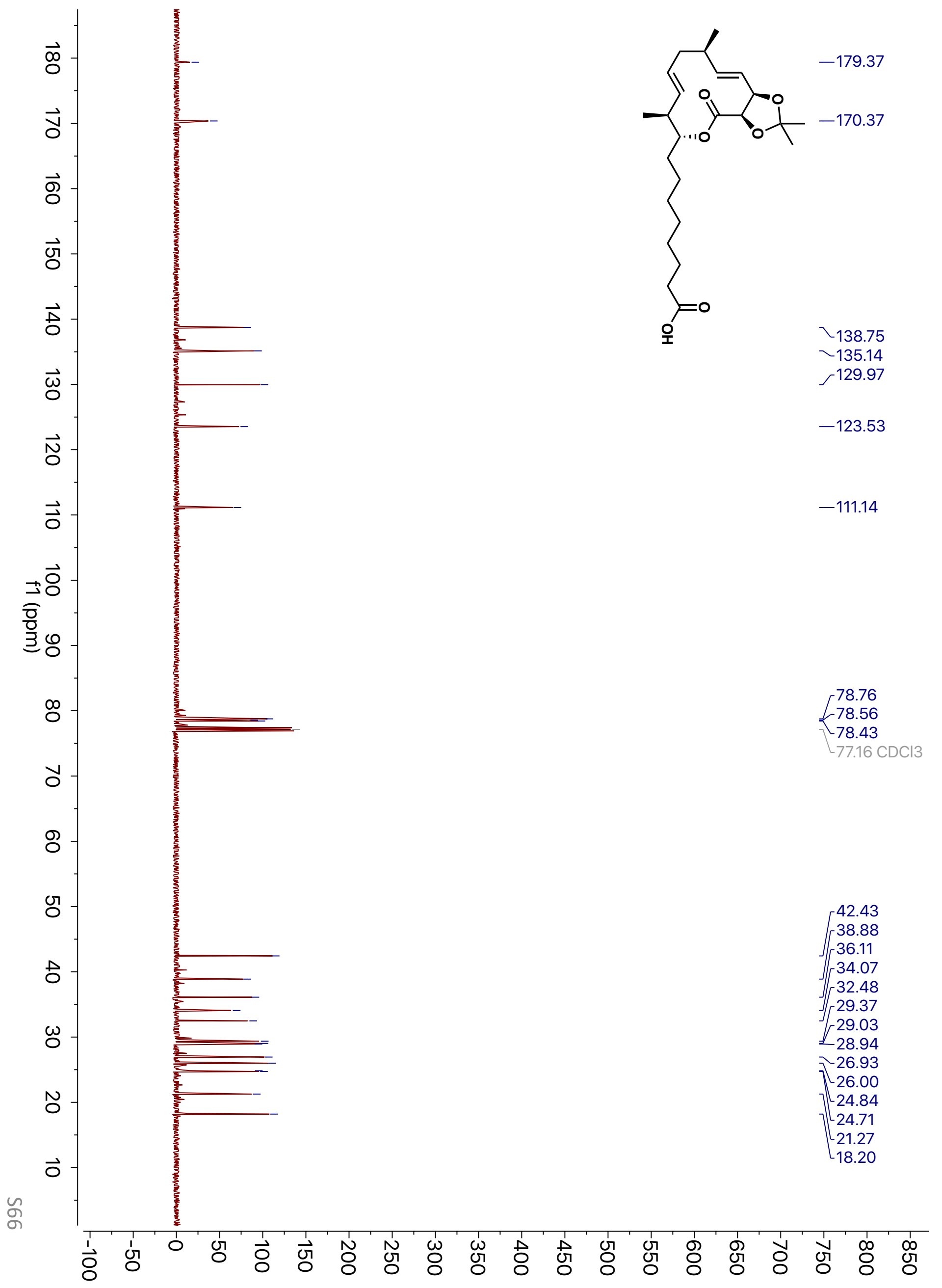



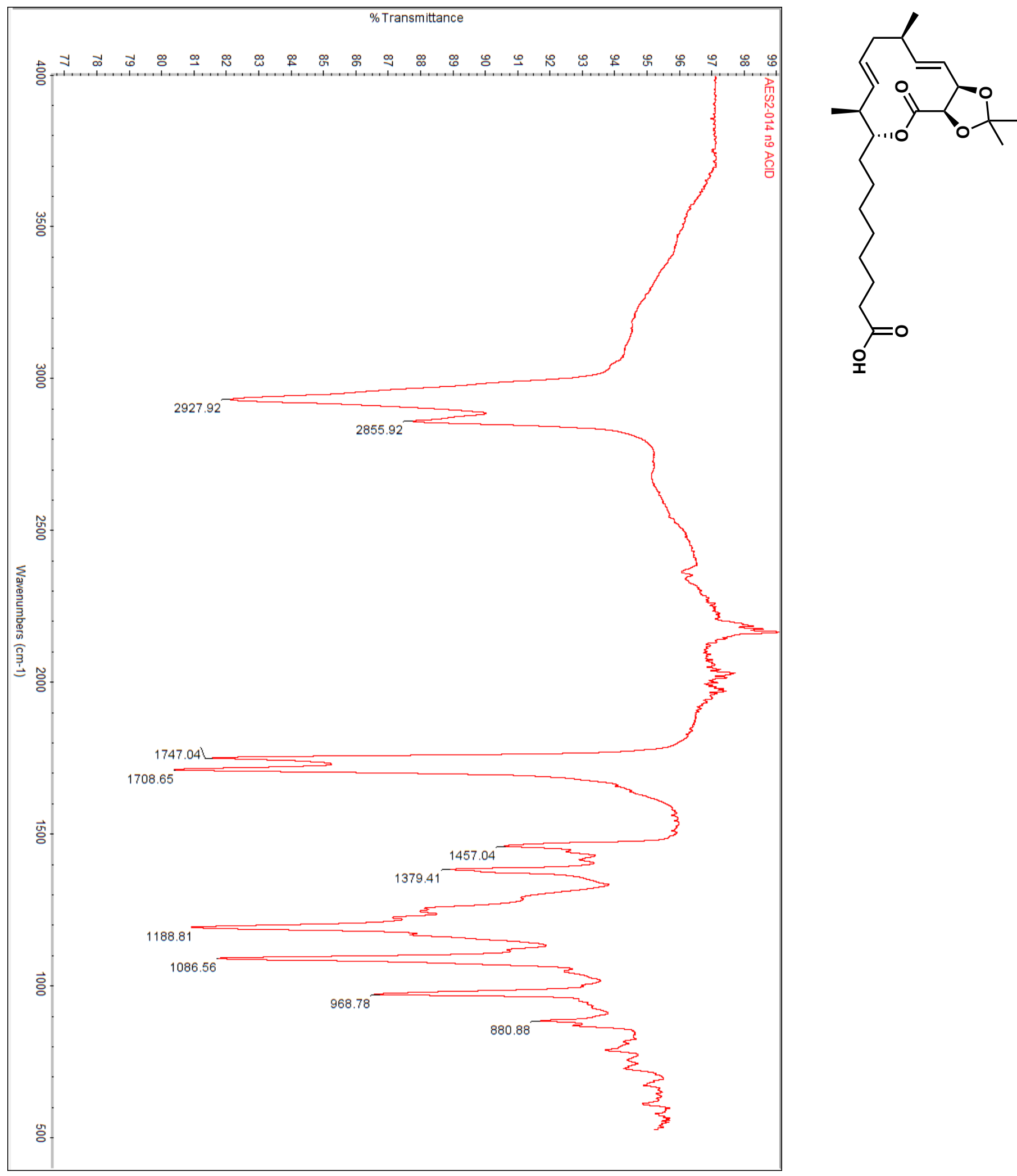


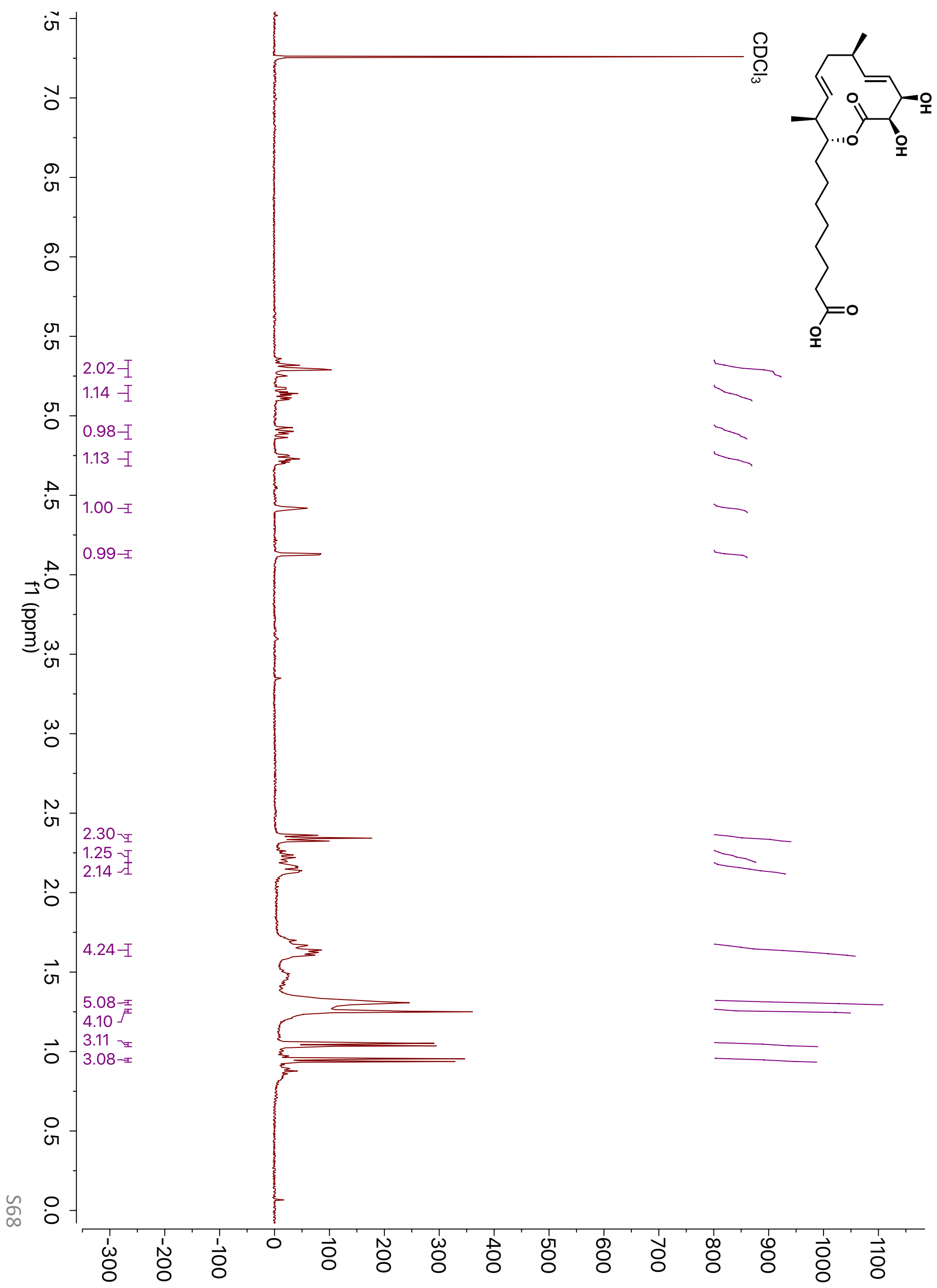




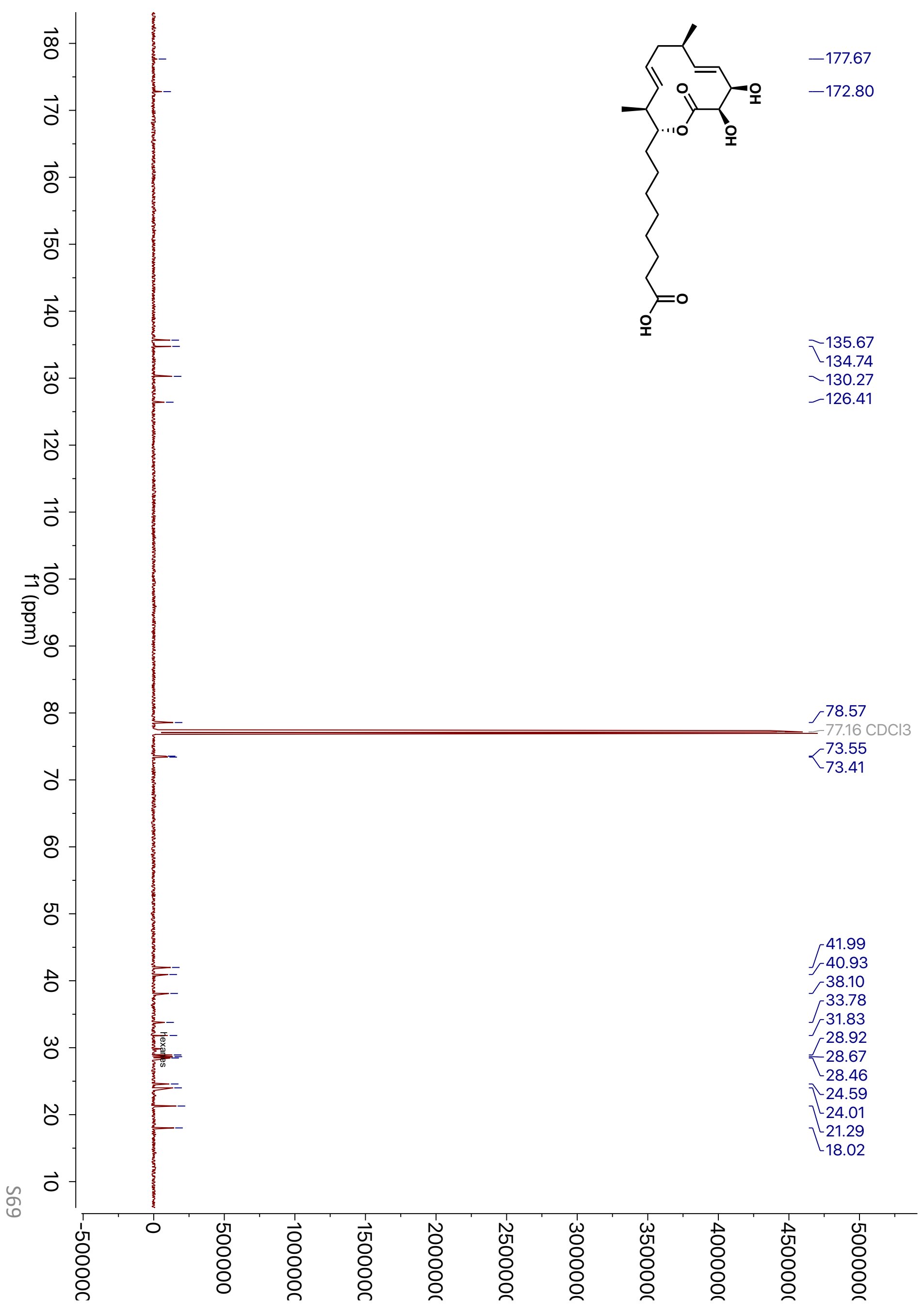




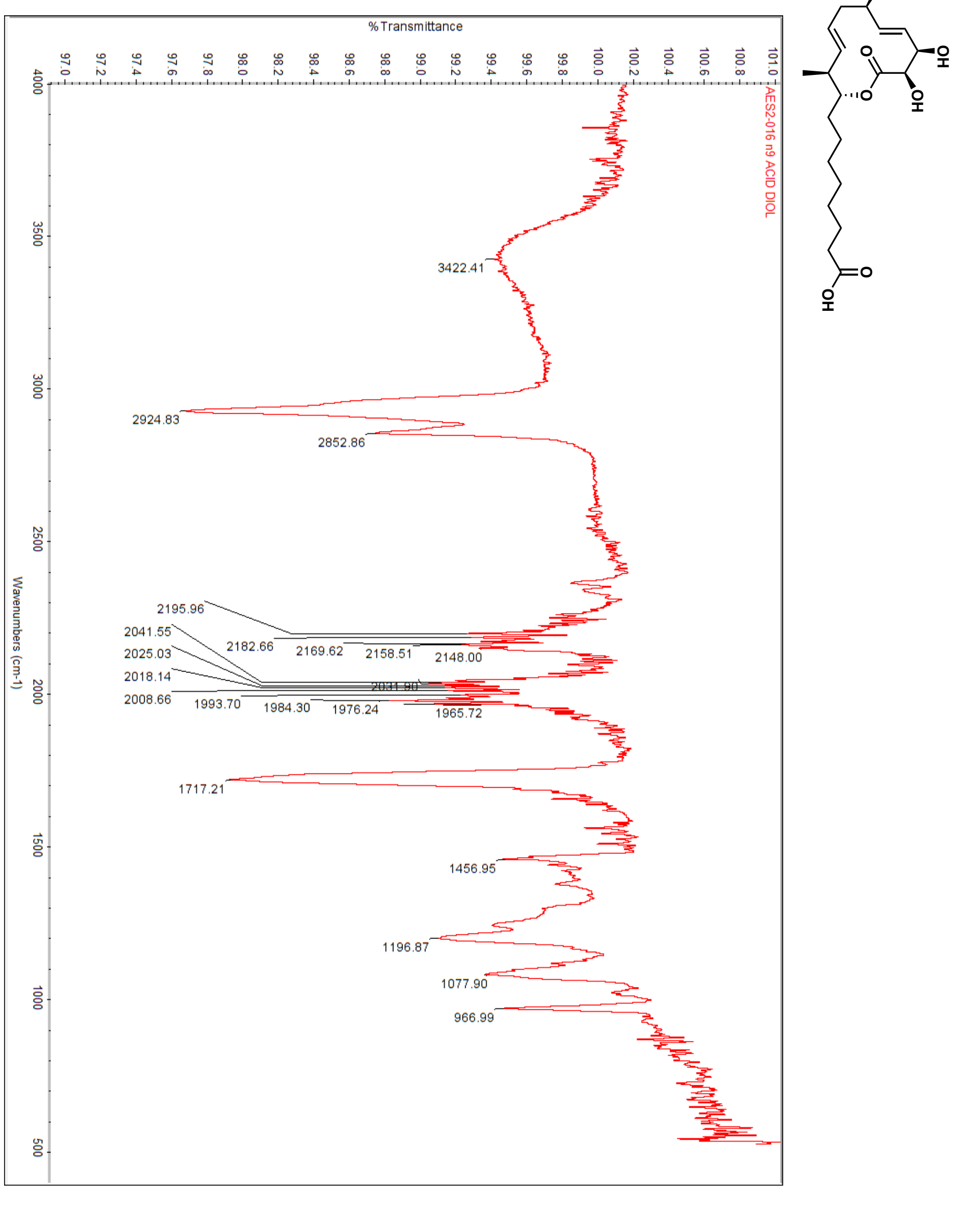




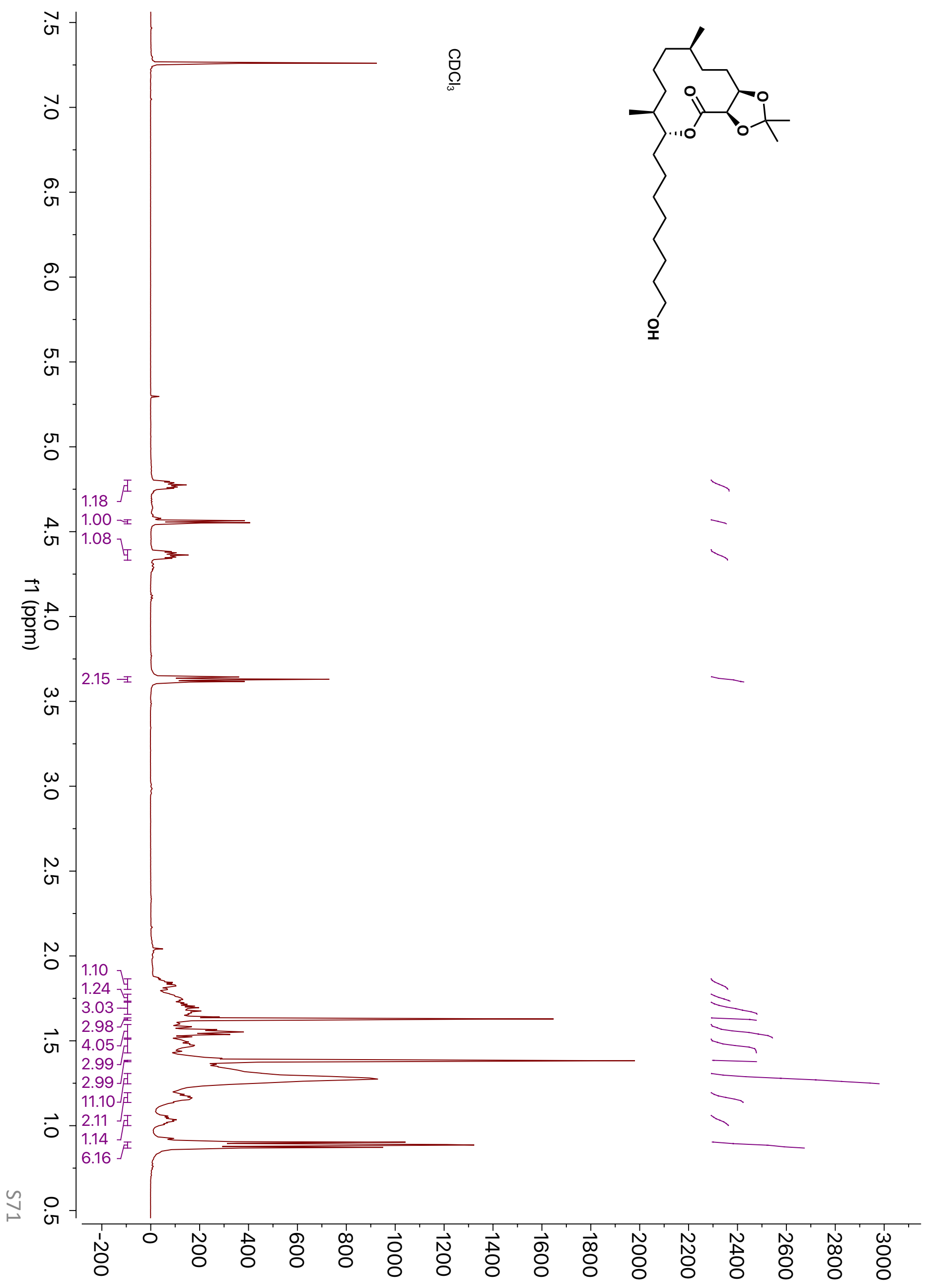




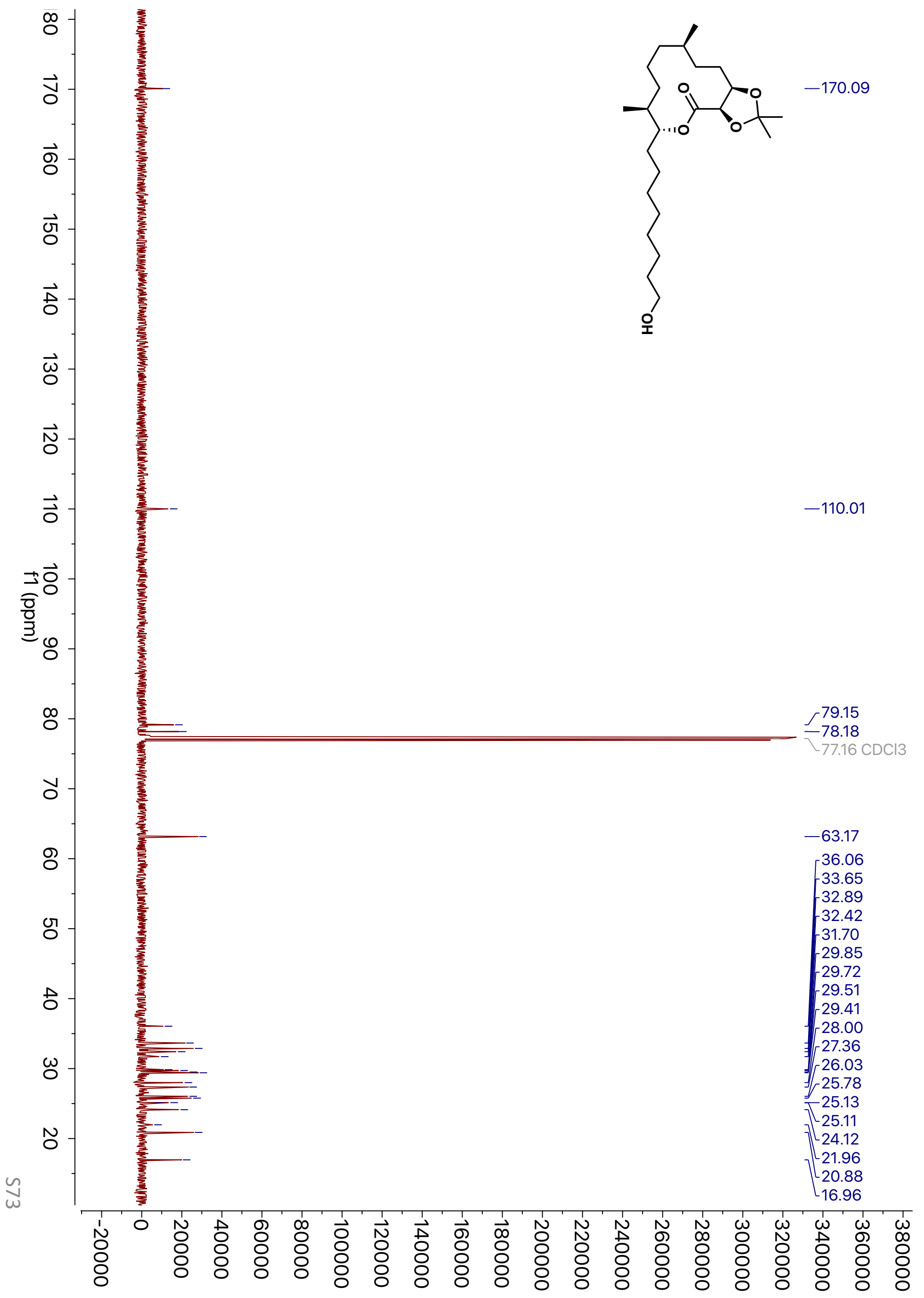




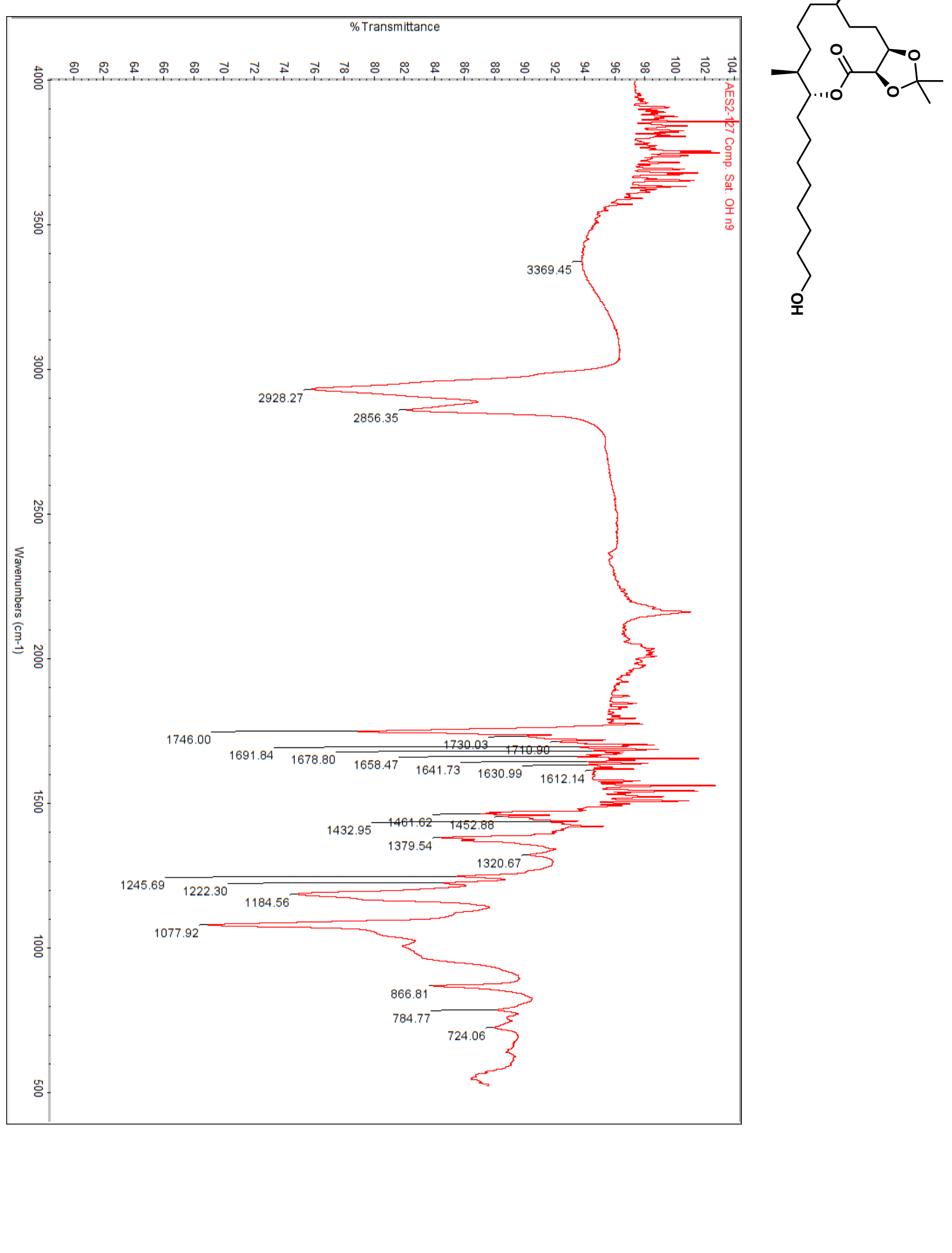




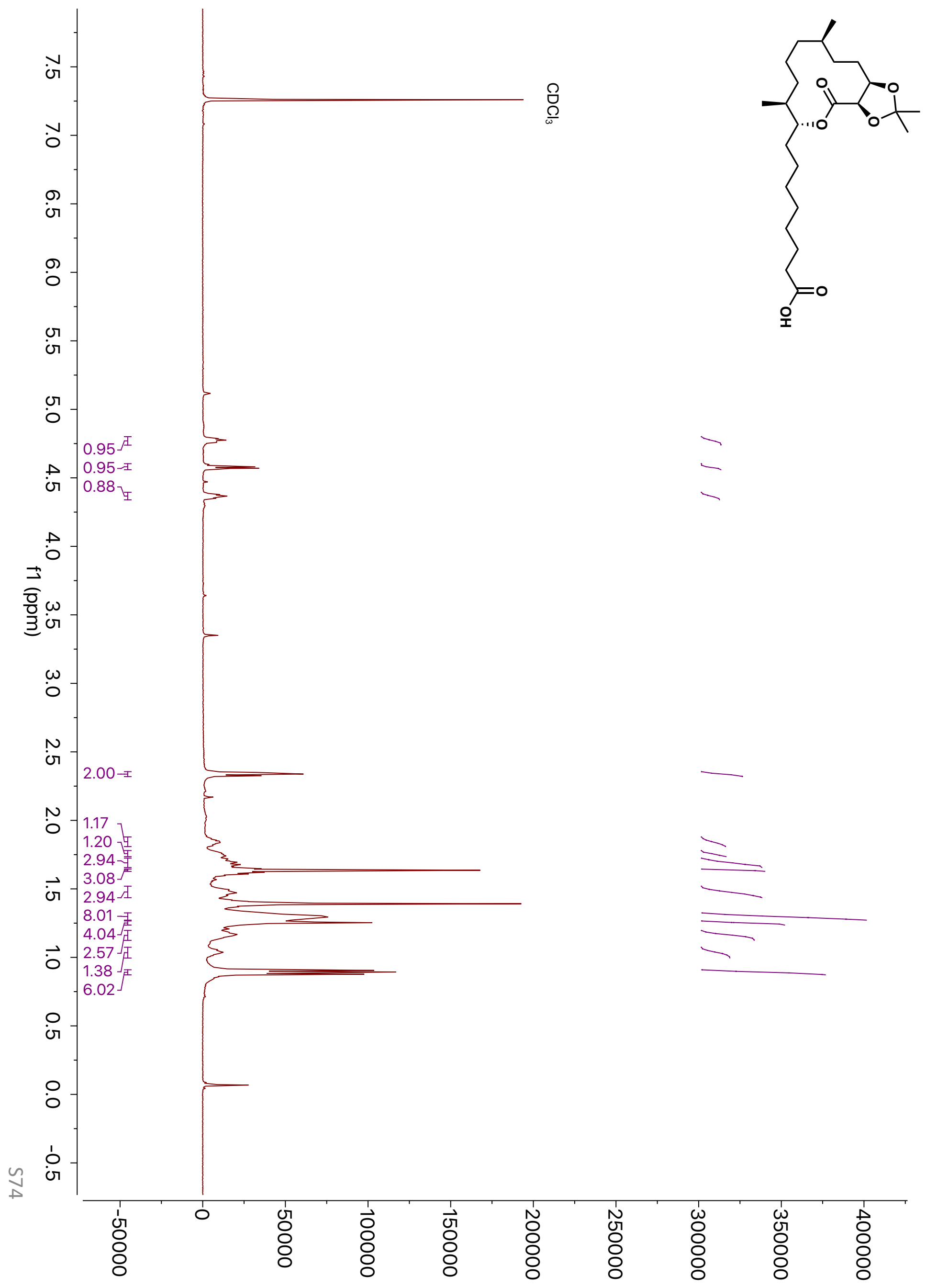




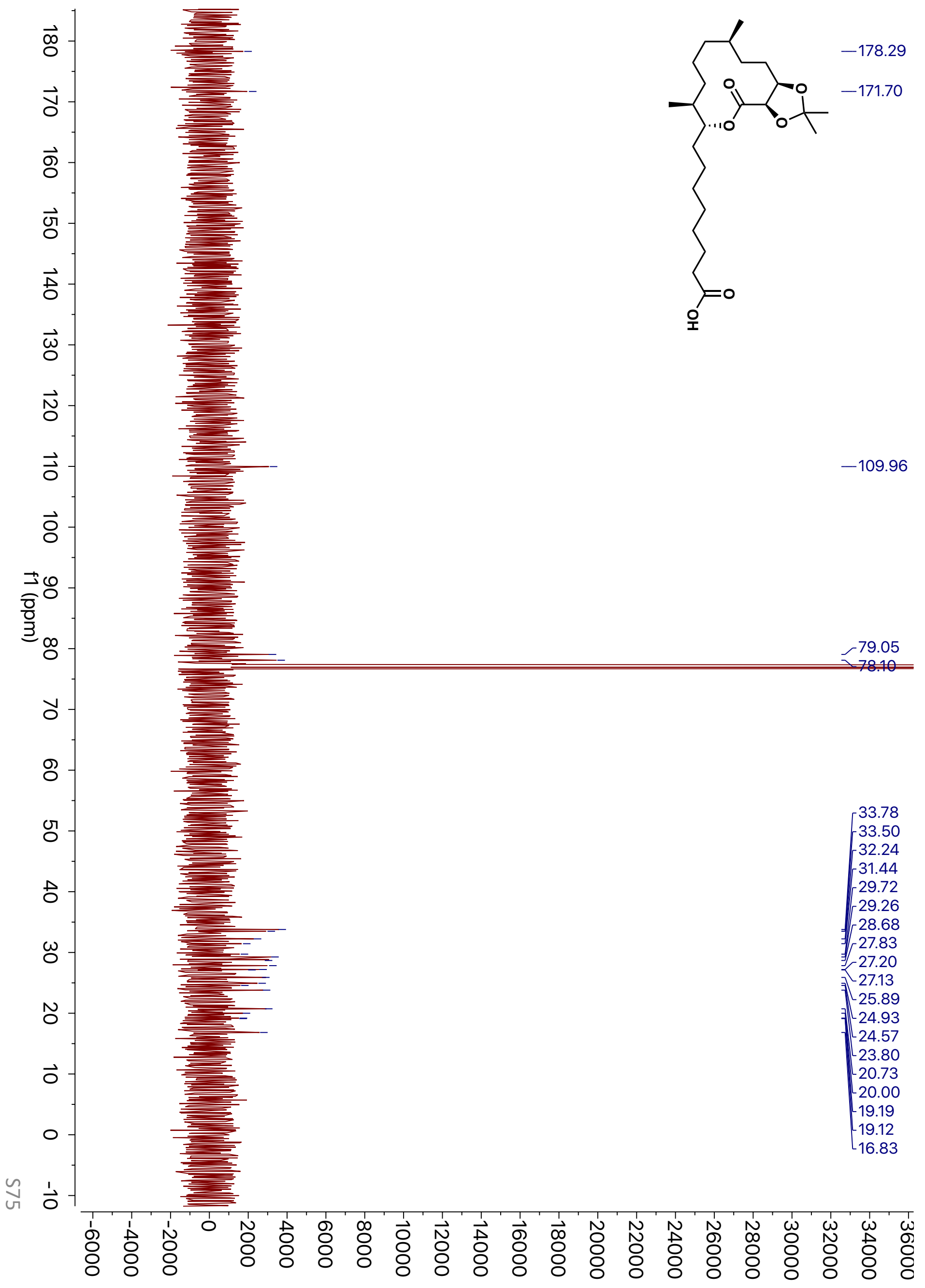




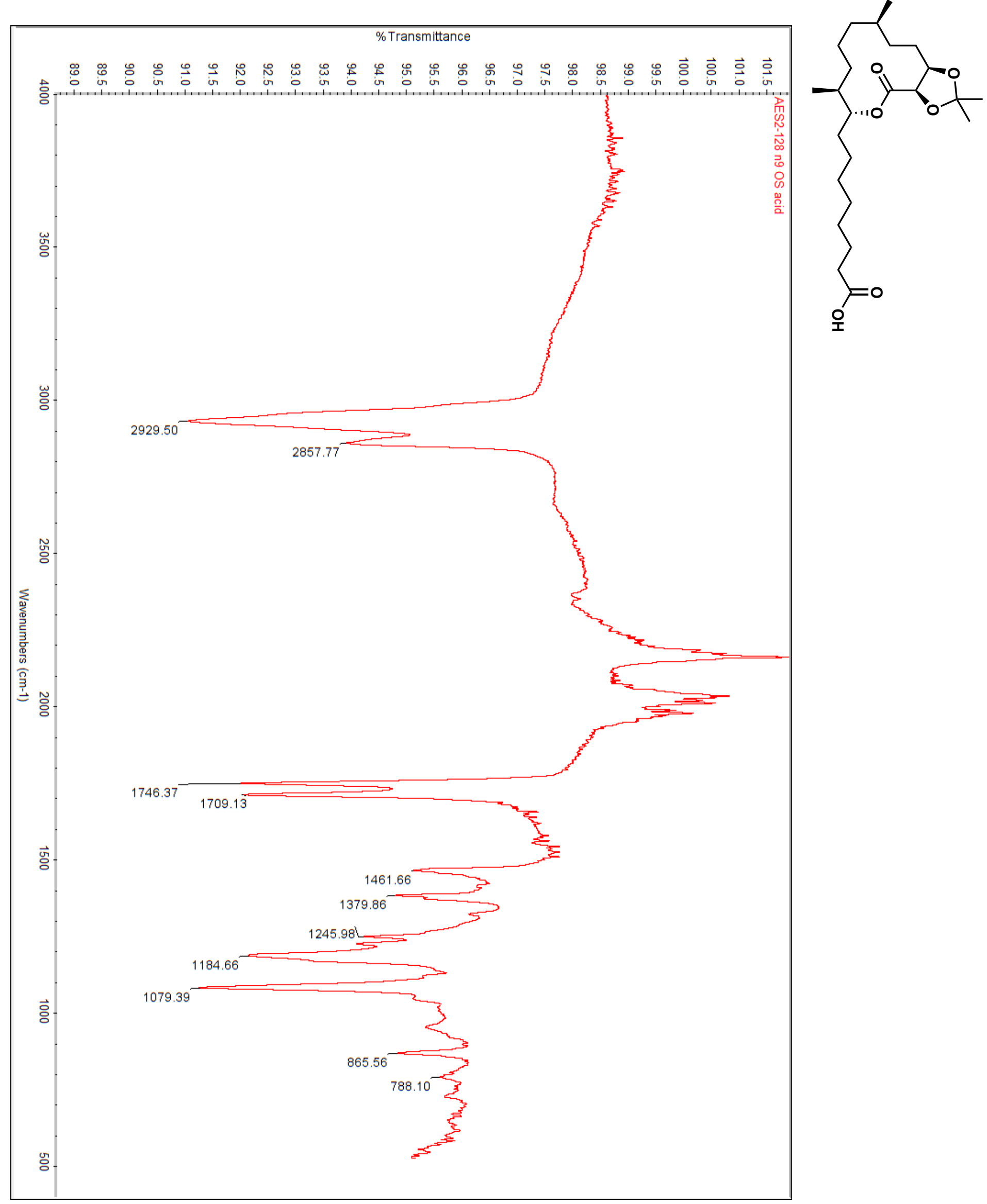




\section{References}

1. Sun, H.; Roush, W. R.; Candito, D. A.; Blanchot, M.; Lautens, M., Synthesis of (S,S)-diisopropyl tartrate (e)-crotylboronate and its reaction with aldehydes: (2r,3r,4r)-1,2-dideoxy-2-ethenyl-4,5-o-(1-methylethylidene)-xylitol. Organic Syntheses 2011, 88, 181-196.

2. Hallside, M. S.; Brzozowski, R. S.; Wuest, W. M.; Phillips, A. J., A concise synthesis of carolacton. Org Lett 2014, 16 (4), 1148-51. 